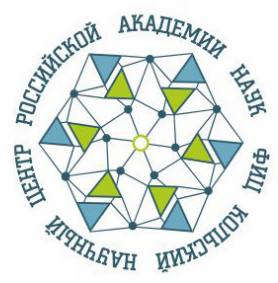

ИНСТИТУТ ЭКОНОМИЧЕСКИХ ПРОБЛЕМ ИМ. Г.П. ЛУЗИНА

ФЕДЕРАЛЬНОГО ИССЛЕДОВАТЕЛЬСКОГО ЦЕНТРА

«КОЛЬСКИЙ НАУЧНЫЙ ЦЕНТР РОССИЙСКОЙ АКАДЕМИИ НАУК»

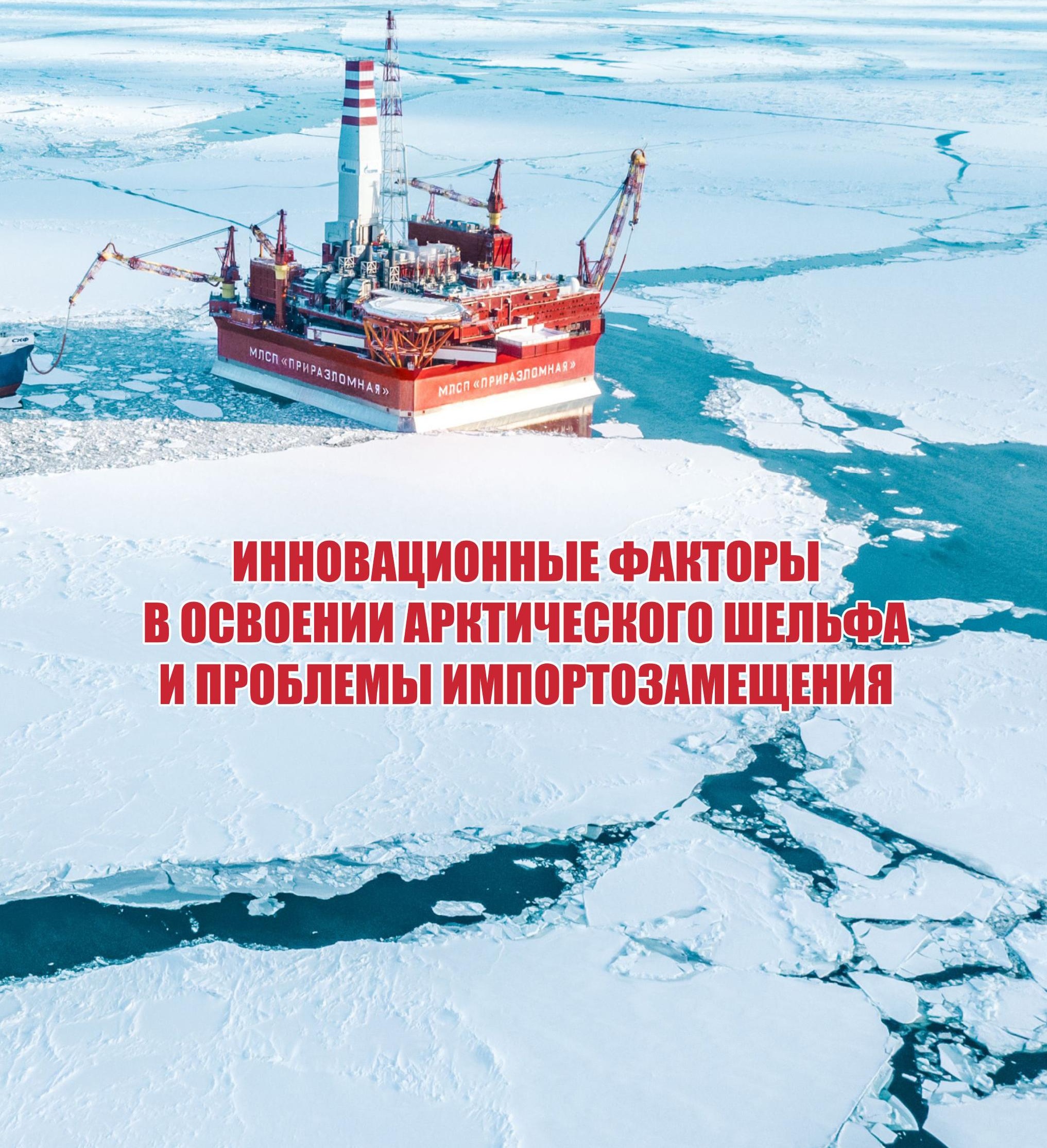


МИНИСТЕРСТВО НАУКИ И ВЫСШЕГО ОБРАЗОВАНИЯ РОССИЙСКОЙ ФЕДЕРАЦИИ ФЕДЕРАЛЬНЫЙ ИССЛЕДОВАТЕЛЬСКИЙ ЦЕНТР «КОЛЬСКИЙ НАУЧНЫЙ ЦЕНТР РОССИЙСКОЙ АКАДЕМИИ НАУК» ИНСТИТУТ ЭКОНОМИЧЕСКИХ ПРОБЛЕМ ИМ. Г. П. ЛУЗИНА

\section{ИННОВАЦИОННЫЕ ФАКТОРЫ В ОСВОЕНИИ АРКТИЧЕСКОГО ШЕЛЬФА И ПРОБЛЕМЫ ИМПОРТОЗАМЕЩЕНИЯ}

Издательство Кольского научного центра 2019 
DOI: $10.37614 / 978.5 .91137 .412 .9$

УДК 338.24:001.985(985)

ББК 65

И6

Печатается по решению Редакционного совета по книжным изданиям ФИЦ КНЦ РАН

Научные рецензенты:

доктор экономических наук, профессор Ф. Д. Ларичкин,

доктор экономических наук, профессор А. А. Ильинский

Коллектив авторов:

А. Н. Виноградов (разделы 1.3, 2.2), Е. С. Горячевская (разделы 1.1, 1.2, 2.1),

А. А. Козлов (глава 3), А. М. Фадеев (раздел 3.2), В. А. Цукерман (введение, глава 1, раздел

2.1 , глава 3, заключение)

И6 Инновационные факторы в освоении арктического шельфа и проблемы импортозамещения : кол. монография / под науч. ред. В. А. Цукермана. - Апатиты : Издательство ФИЦ КНЦ РАН, 2019. - 80 с.: ил.

ISBN 978-5-91137-412-9

В коллективной монографии рассмотрены методические вопросы управления процессом освоения ресурсного потенциала арктического шельфа Российской Федерации, предложена интегральная методика оценки инвестиционной привлекательности компаний нефтегазового комплекса, намечены приоритетные направления мероприятий по уменьшению рисков грузопотоков углеводородного сырья на высокоширотных трассах Северного морского пути, рассмотрены возможности для повышения системности природоохранной деятельности северных регионов России. Охарактеризованы неизвестные ранее «большие вызовы», связанные со спецификой природной среды Арктики, даны рекомендации по развитию инновационных технологий контроля и профилактики опасных процессов при строительстве и эксплуатации мегаразмерных природно-технических комплексов на мерзлых грунтах в зонах стабильности газогидратов. Определены руководящие принципы политики импортозамещения, обеспечивающие достижение целей, намеченных в национальной стратегии освоения арктических нефтегазовых месторождений.

Монография предназначена для широкого круга специалистов, в том числе для преподавателей высших и средних специальных учебных заведений, научных работников. Работа может быть использована как учебное пособие для аспирантов и студентов.

Монография подготовлена с учетом научных исследований, выполненных при финансовой поддержке гранта РФФИ № 17-02-00248 «Инновационные факторы в освоении арктического шельфа и проблемы импортозамещения».

УДК 338.24:001.985(985)

ББК 65

Научное издание

Редактор Е. Н. Еремеева

Технический редактор В. Ю. Жиганов

Подписано в печать 24.12.2019. Формат бумаги 70×108 1/16

Усл. печ. л. 7. Заказ № 30. Тираж 500 экз.

ISBN 978-5-91137-412-9
(C) Институт экономических проблем им. Г. П. Лузина ФИЦ КНЦ РАН, 2019

(C) ФГБУН ФИЦ «Кольский научный центр Российской академии наук», 2019

( ) ФГБУН ФИЦ «Единая геофизическая служба Российской академии наук», 2019 


\section{ОГЛАВЛЕНИЕ}

ВВЕДЕНИЕ.

1. УГЛЕВОДОРОДНЫЕ РЕСУРСЫ РОССИЙСКОЙ АРКТИКИ И РИСКИ

ИХ ОСВОЕНИЯ.

4

1.1. Освоение нефтегазовых ресурсов при отработке месторождений арктического шельфа.

6

.2. Оценка инвестиционной привлекательности арктических предприятий нефтегазового сектора.

1.3. Движущие силы и риски грузопотоков углеводородного сырья на высокоширотных трассах Северного морского пути и Баренцева моря.

1.4. Освоение нефтегазовых месторождений и природоохранная деятельность северных территорий

2. ИННОВАЦИОННЫЕ ПОДХОДЫ

К ОСВОЕНИЮ АРКТИЧЕСКОГО ШЕЛЬФА

2.1. Инновационное освоение арктического шельфа: проблемы, безопасность, перспективы.

2.2. Обеспечение промышленной безопасности в Арктике: новые «большие вызовы» и перспектива их преодоления с использованием инновационных технологий и проектного управления природно-технической мегасистемой

3. СТРАТЕГИЯ ИМПОРТОЗАМЕЩЕНИЯ ПРИ ОСВОЕНИИ

УГЛЕВОДОРОДНОГО СЫРЬЯ.

3.1. Актуальность импортозамещения при добыче углеводородов на арктическом шельфе.

3.2. Разработка и реализация стратегии импортозамещения............. 46

ЗАКЛЮЧЕНИЕ ................................................. 61

ЛИТЕРАТУРА.................................................. 64 


\section{ВВЕДЕНИЕ}

Нефтегазовый сектор промышленного комплекса Российской Федерации формирует существенную долю валютных поступлений страны и, соответственно, консолидированного бюджета, динамику поступления доходов северных регионов и расширение числа высокотехнологичных рабочих мест для их населения.

Важнейшим резервом углеводородных ресурсов являются месторождения Севера и Арктики. Освоение ресурсов нефтегазового комплекса увеличивает экономический потенциал северных регионов, способствует развитию современной инфраструктуры.

Несмотря на значительные перспективы, освоение арктического шельфа Российской Федерации связано с серьезными вызовами и проблемами, прежде всего обусловленными спецификой природной среды и проявлением рискфакторов, отсутствующих в умеренных широтах, что требует принципиального технологического и технического перевооружения отрасли. Кроме того, для обеспечения конкурентоспособности арктических промыслов необходимо существенное повышение качественных и количественных показателей извлечения сырья, чего нельзя добиться без разработки и практической реализации технологических инноваций.

Применяемые сегодня традиционные принципы и механизмы управления освоением природных ресурсов на российском арктическом шельфе сложились в тот период, когда темпы «покорения» Севера заметно опережали процессы формирования институционального блока, в том числе национальных и отраслевых стандартов, а также технических регламентов. Присущие им нестабильность, изменчивость и неполнота правил и норм изучения и освоения природных ресурсов могут приводить к дополнительным рискам для недропользователей. Так, в настоящее время отсутствует научно обоснованный экономический механизм контроля за выполнением лицензионных соглашений. Природные ресурсы российского шельфа Арктики осваиваются с низкой эффективностью вследствие недостаточного государственного регулирования межбюджетных отношений в области природопользования.

Инновационное развитие Севера и Арктики в определенной мере зависит от промышленной политики. Это свидетельствует о необходимости пересмотра методов и моделей диагностики корпораций-операторов и целевых задач региональной экономики. Конечной целью такого сопоставления можно считать выработку унифицированной системы региональных и корпоративных индикаторов и количественных показателей, которая даст возможность бесконфликтно и оптимально выбирать приоритетные направления развития северного макрорегиона на конкретных стадиях освоенческой программы. Следует отметить, что согласование корпоративной и государственной инновационной политики требует фундаментальных исследований, структурных преобразований и перестройки экономики регионов Севера и Арктики. Повышение эффективности работы ресурсных корпораций и развитие арктического макрорегиона многократно обсуждались на государственном уровне, а также в общественных и научных организациях России. Тем не менее основная часть наиболее значимых инновационных проектов на Севере и в Арктике не реализуется. Целевые задачи и интересы корпораций, 
производственные мощности которых расположены непосредственно в северных и арктических регионах, а также масштабность их использования для социально-экономического развития страны и регионов российского Севера и Арктики должны быть соизмеримы с современными вызовами и ограничениями.

Для реализации стратегических государственных задач необходимо создание единой долговременной программы действий, основанной на системном подходе к освоению арктического шельфа в условиях последовательного проведения политики импортозамещения. Эффективная реализация этой политики способна увеличить число факторов развития северного макрорегиона, поскольку создадутся благоприятные условия для вовлечения широкого круга российских промышленных предприятий, геологоразведочных и научно-исследовательских организаций в производство инновационных товаров и услуг. В конечном итоге это должно послужить стимулом к качественно новому промышленному, инфраструктурному и социальному развитию всей территории Российской Арктики.

Монография подготовлена авторским коллективом в составе: Виноградова А. Н. (разделы 1.3, 2.2), Горячевской Е. С. (разделы 1.1, 1.2, 2.1), Козлова А. А. (глава 3), Фадеева А. М. (раздел 3.2), Цукермана В. А. (введение, глава 1, раздел 2.1, глава 3 , заключение). 


\section{1. УГЛЕВОДОРОДНЫЕ РЕСУРСЫ РОССИЙСКОЙ АРКТИКИ И РИСКИ ИХ ОСВОЕНИЯ}

\section{1. Освоение нефтегазовых ресурсов при отработке месторождений арктического шельфа}

По данным исследований геологической службы CША (USGS), Арктике принадлежит порядка 13 \% мировых запасов нефти и до 30 \% мировых запасов газа (неразведанных). На шельфе Аляски в 2016 г. было открыто месторождение нефти Смит-Бэй с запасами порядка 2,5 млрд т. В 2017 г. обнаружено месторождение Уиллоу с запасами нефти 45 млн т.

Для России арктический шельф считается основным резервом нефтегазовых ресурсов, которые могут быть отнесены к числу уникальных мировых районов, где сосредоточены потенциальные запасы углеводородов.

На арктическом шельфе России открыто 26 крупных месторождений, в том числе девять газоконденсатных (Ледовое, Русановское, Штокмановское, Поморское, Ленинградское, Крузенштернское, Северо-Каменномысское, Харасавейское, Юрхаровское), четыре нефтяных (Приразломное, Варандейское, Медынское, Долгинское), девять газовых (Лудловское, Обское, Мурманское, Северо-Кильдинское, Каменномысское, Семаковское, Чугорьяхинское, ТотаЯхинское, Антипаютинское), четыре нефтегазоконденсатных (Победа, Белоостровское, Песчаноозерское, Северо-Гуляевское) [1]. По оценкам специалистов, в структуре углеводородов российского шельфа Арктики доминируют запасы газа, на долю которого приходится около 75 \% [2].

Быстрое увеличение добычи нефти из сланцевых месторождений в США в 2000-х гг. явилось важнейшим фактором роста мирового предложения, что обусловлено разработкой и реализацией инновационных проектов добычи и освоения и, соответственно, повышением цен на нефть.

Как отмечал министр природных ресурсов и экологии России С. Донской 13 марта 2017 г. в интервью ТАСС, «на протяжении как минимум ближайших пятидесяти лет ни сланцевые месторождения, ни альтернативные источники не смогут заместить традиционные углеводороды в энергетике и промышленности в целом. При этом главный резерв традиционных углеводородов - это арктический шельф, где возможны открытия крупных месторождений. И, в частности, такие открытия весьма вероятны в российской Арктической зоне» [3].

Хозяйственная практика, опирающаяся на ускоренную разработку и незамедлительную реализацию инновационных технологий освоения сланцевых месторождений нефти, «обвалила» импорт нефти в США из Саудовской Аравии и создала предпосылки для экспорта сжиженного природного газа из США в Европу. По ценовому порогу экономически оправданной добычи нефти сланцевые месторождения сравнялись с традиционными типами нефтяных полей в Арктике, что значительно ухудшило перспективу выведения на мировые рынки углеводородов сырьевых продуктов из Арктической зоны Российской Федерации. В этой обстановке конкурентоспособность и даже «выживаемость» большей части оффшорных проектов в Российской Арктике стали еще в большей степени зависимыми от технологического прогресса в сфере обустройства промыслов и обеспечения их максимальной производительности в сочетании с гарантированным поддержанием экологической безопасности. 
Следовательно, на первый план автоматически вышли проблемы импортозамещения, поскольку в настоящее время более 80 \% технических средств управления и геофизического контроля добычи нефти и газа в нефтегазовом секторе российской индустрии представлено импортной продукцией, весьма «чувствительной» к воздействию санкционных ограничительных режимов.

Производство наукоемкой аппаратуры для строительства современных «интеллектуальных» промыслов (smart wells) в России было полностью разрушено в процессе рыночных реформ 1990-х гг., поэтому рассчитывать на быстрое воссоздание этой высокотехнологичной области не приходится. В связи с этим Россия с помощью геополитических методов пытается противостоять поддерживаемой конкурентами тенденции снижения мировых цен на нефть и газ ниже минимального ценового порога себестоимости продукции арктических промыслов. В ряду таких «защитных» мер можно в первую очередь назвать переговоры со странами ОПЕК и другими крупными производителями нефти о замораживании цен или сокращении добычи. В конце 2016 г. было подписано первое соглашение по этому вопросу, в 2017 г. оно дополнено соглашением о сокращении добычи нефти до 32,5 млн баррелей в сутки (из этого объема 300 тыс. баррелей составляет доля России). Достигнутые договоренности способствовали временной стабилизации цен на нефть на уровне 55-66 долл. США [4].

В европейских странах дальнего зарубежья в этот период наметился спад собственной добычи газа как вследствие снижения масштабов отбора из «старых» малорентабельных месторождений Нидерландов, так и вследствие принятия жестких ограничений по темпам и уровням экстракции с целью предотвращения наведенной (техногенной) сейсмической активности. В 2018 г. крупнейшие производители газа - Норвегия, Великобритания и Нидерланды сократили свои поставки на европейский рынок в общей сложности на 9,2 млрд м³. По официальным прогнозам государственных отраслевых ведомств, снижение добычи газа европейскими странами продолжится и в дальнейшем.

На фоне понижающегося тренда наблюдается повышение доли газа по отношению к углю в энергетических балансах всех стран, чему в значительной мере способствовали решения парижской Климатической конференции ООН: в декабре 2015 г. более 150 глав государств и правительств одобрили на мировом уровне новое соглашение о сдерживании роста средней планетарной температуры ниже $2{ }^{\circ} \mathrm{C}$ сверх уровней доиндустриального периода. Церемония подписания Парижского соглашения состоялась 26 апреля 2016 г., а официальное вступление в силу произошло 4 ноября 2016 г. По оценкам ПАО «Газпром», Парижское соглашение повысило конкурентную значимость газа по сравнению с углем. Важнейшим стимулом использования газа в мире может стать тот факт, что «углеродный след» при использовании природного газа ниже, чем при использовании угля, в два раза [5].

В Российской Федерации в настоящее время запасы газа отрабатываются только в континентальной части Арктики, при этом поставки газа из этих районов служат основным фактором экономического благосостояния, хотя строгой корреляции между экспортом газа и импортом жизнеобеспечивающей продукции и не наблюдается. Так, по данным Федеральной службы государственной статистики РФ, в регионах Севера и Арктики сальдо внешней 
торговли в 2017 г. по сравнению с 2010 г. снизилось на 22,1 \%, а экспорт и импорт товаров и услуг за аналогичный период увеличились на $39,0 \%$ и в 7,4 раза соответственно [6]. Сальдо внешней торговли в 2017 г. по сравнению с 2010 г. снизилось на $22,1 \%$. При этом экспорт и импорт товаров и услуг за аналогичный период увеличились на $39,0 \%$ и в 7,4 раза соответственно. В определенные периоды наблюдается отрицательная динамика инвестиций в основной капитал и прямых иностранных инвестиций. На сегодняшний день Российская Федерация разрабатывает запасы газа только в континентальной части Арктики, при этом на шельфовых месторождениях промышленная добыча пока не ведется.

Сравнительный анализ прибыли и выручки основных предприятий Севера и Арктики, осуществляющих деятельность по добыче углеводородных ресурсов, за последние шесть лет выполнен на основе фактографических данных, приведенных в табл. 1-6.

ПАО «Газпром»

Таблица 1

Показатели деятельности ПАО «Газпром», тыс. руб. [7]

\begin{tabular}{|l|c|c|c|c|c|c|}
\hline \multicolumn{1}{|c|}{ Показатель } & 2013 г. & 2014 г. & 2015 г. & 2016 г. & 2017 г. & 2018 г. \\
\hline Выручка & 3148487449 & 3148695244 & 3340147352 & 2941335565 & 2871912237 & 3681907763 \\
\hline Себестоимость & 1141753251 & 1182967479 & 1258623586 & 1223024318 & 1165772115 & 1263428862 \\
\hline $\begin{array}{l}\text { Прибыль } \\
\text { от продаж }\end{array}$ & 961826778 & 921245510 & 811940021 & 332673919 & 375511399 & 1024124013 \\
\hline
\end{tabular}

Выручка предприятия за рассматриваемый период выросла на 16,9 \%, себестоимость продажи газа выросла на 10,7 \%, прибыль от продаж возросла на $6,5 \%$.

В 2018 г. ПАО «Газпром» добыл 498,7 млрд м газа, продемонстрировав рост на 5,6 \%, или на 26,6 млрд м ${ }^{3}$. Продолжалось активное развитие добычного потенциала, в первую очередь на полуострове Ямал. ПАО «Газпром» поставил в европейское дальнее зарубежье 201,9 млрд м³ газа. Это новый - третий подряд - рекорд по объему годового экспорта. Доля газа в европейском потреблении также выросла до исторического максимума - 36,8 \%. Потребителям Российской Федерации в 2018 г. реализовано 239,7 млрд м ${ }^{3}$ газа, что на 9,8 млрд $\mathrm{M}^{3}$, или на 4,3\%, превысило уровень 2017 г. в основном благодаря более холодным погодным условиям в I и IV кварталах 2018 г. Рост поставок газа в основном отмечался по предприятиям энергетики, агрохимии и коммунальнобытового комплекса. На увеличение чистой выручки от продаж также оказал влияние рост цен реализации.

Объем реализации продуктов нефтегазопереработки в 2018 г. составил 68,9 млн т. Чистая выручка от продажи составила 2 179,8 млрд руб. (за вычетом акциза, НДС и таможенных пошлин), увеличившись в связи с ростом средних цен, а также с увеличением объемов реализации в натуральном выражении нефти потребителям, находящимся на территории России и стран дальнего зарубежья. Увеличение общего объема реализации продуктов нефтегазопереработки ПАО «Газпром» в 2018 г. связано с ростом объемов 
производства продукции на российских нефтеперерабатывающих заводах и соответствующим увеличением объемов реализации. Снижение объемов реализации жидкого гелия обусловлено сокращением продаж на экспорт в связи с ростом потребности на внутреннем рынке и перераспределением объемов в пользу газообразного гелия.

В рамках НИОКР ПАО «Газпром» широко применялись наукоемкие технологии при реализации стратегически значимых проектов строительства магистральных газопроводов «Турецкий поток» и «Сила Сибири». При этом используемые при реализации проекта «Сила Сибири» инновационные технологии и оборудование созданы либо в рамках программы НИОКР ПАО «Газпром» и его дочерних обществ, либо российскими разработчиками по техническим требованиям ПАО «Газпром».

Промыиленное предприятие ПАО «Газпром» $О A O$ «Севернефтегазпром»

Таблица 2

Показатели деятельности ОАО «Севернефтегазпром», тыс. руб. [8]

\begin{tabular}{|l|c|c|c|c|c|c|}
\hline \multicolumn{1}{|c|}{ Показатель } & \multicolumn{1}{c|}{2013 г. } & \multicolumn{1}{c|}{2014 г. } & 2015 г. & 2016 г. & 2017 г. & 2018 г. \\
\hline Выручка & 34501203 & 37214140 & 49463090 & 50365483 & 49326224 & 47740178 \\
\hline Себестоимость & 25670964 & 29021066 & 29527079 & 30486154 & 41443962 & 43798793 \\
\hline Прибыль от продаж & 7723489 & 7015284 & 18684495 & 18611472 & 6714036 & 2545943 \\
\hline
\end{tabular}

За 2013-2018 гг. выручка выросла на 38,4 \%, себестоимость — на 70,6 \%, при этом произошло снижение прибыли от продаж на 67,0 \%.

Долгосрочные договоры на реализацию добываемого газа, которые заключены у ОАО «Севернефтегазпром», обеспечивают регулярное поступление выручки. Ее рост за последние годы обусловлен ростом цены на реализацию природного газа.

Совместно с зарубежными партнерами BASF/Wintershall и OMV для повышения эффективности совместной эксплуатации сеноманских и туронских залежей Южно-Русского нефтегазоконденсатного месторождения инициирован проект по созданию «цифрового двойника» производственных объектов ОАО «Севернефтегазпром».

ПАО «НК “Роснефть”»

Таблица 3

Показатели деятельности ПАО «НК “Роснефть”», тыс. руб. [9]

\begin{tabular}{|l|c|c|c|c|c|c|}
\hline \multicolumn{1}{|c|}{ Показатель } & 2013 г. & 2014 г. & 2015 г. & 2016 г. & 2017 г. & \multicolumn{1}{c|}{2018 г. } \\
\hline Выручка & 3544443140 & 4299680200 & 3831094945 & 3930139846 & 4892934388 & 6968248044 \\
\hline Себестоимость & 1970725706 & 2451243380 & 2612932721 & 2846770153 & 3459587329 & 4815224782 \\
\hline Прибыль от продаж & 198856294 & 155455050 & 116800058 & 34481011 & 359957079 & 625698083 \\
\hline
\end{tabular}

Выручка компании за 2013-2018 гг. выросла на 96,6 \%, себестоимость продукции — на 144,3 \%, прибыль от продаж — на 214,7 \%. 
В 2018 г. ПАО «НК “Роснефть”» повысило добычу углеводородов до 230 млн т нефтяного эквивалента. Это на 2,2 \% выше уровня 2017 г. Основными факторами роста активов стали увеличение мощностей Восточно-Мессояхского месторождения и совершенствование системы технологического опробования и транспортирования нефти на отдельных предприятиях ПАО «НК “Роснефть"». Добыча газа в 2018 г., по сравнению с предыдущим периодом, составила 67,3 млрд м $^{3}$, что обусловило снижение на $2 \%$ по сравнению с 2017 г.

Промышленное предприятие ПАО «НК “Роснефть”» $А O$ «Сибнефтегаз»

Таблица 4

Показатели деятельности АО «Сибнефтегаз», тыс. руб. [10]

\begin{tabular}{|l|r|r|r|r|r|c|}
\hline \multicolumn{1}{|c|}{ Показатель } & \multicolumn{1}{c|}{2013 г. } & \multicolumn{1}{c|}{2014 г. } & \multicolumn{1}{c|}{2015 г. } & \multicolumn{1}{c|}{2016 г. } & \multicolumn{1}{c|}{2017 г. } & 2018 г. \\
\hline Выручка & 14000029 & 15384369 & 16605355 & 17144936 & 17825255 & 17026902 \\
\hline Себестоимость & 5767266 & 7610250 & 10099990 & 11079783 & 12802584 & 12478818 \\
\hline Прибыль от продаж & 7936155 & 7447911 & 6091240 & 5538991 & 4433430 & 3875032 \\
\hline
\end{tabular}

За период 2013-2018 гг. выручка выросла на 21,6 \%, себестоимость - на 116,4 \%, прибыль от продаж снизилась на 51,2 \%.

$\Pi A O « Н О В А Т Э К »$

Таблий 5

Показатели деятельности ПАО «НОВАТЭК», тыс. руб. [11]

\begin{tabular}{|l|r|c|c|c|c|c|}
\hline \multicolumn{1}{|c|}{ Показатель } & \multicolumn{1}{c|}{2013 г. } & 2014 г. & 2015 г. & 2016 г. & 2017 г. & 2018 г. \\
\hline Выручка & 245077487 & 318920540 & 412703472 & 429335368 & 468541723 & 560647664 \\
\hline Себестоимость & 90922711 & 123290982 & 208273496 & 226469430 & 244797897 & 310336324 \\
\hline $\begin{array}{l}\text { Прибыль } \\
\text { от продаж }\end{array}$ & 63127105 & 83361616 & 84467174 & 81414979 & 96411878 & 117251829 \\
\hline
\end{tabular}

За период 2013-2018 гг. выручка выросла на 128,8 \%, себестоимость на $241,3 \%$, прибыль от продаж - на 85,7 \%.

Добыча природного газа ПАО «НОВАТЭК» в 2018 г. составила 549,1 млрд баррелей нефтяного эквивалента, в том числе 11,8 млн т жидких углеводородов, 69 млрд м ${ }^{3}$ природного газа. По сравнению с 2017 г. добыча углеводородов выросла на 35,8 млн баррелей, что связано в первую очередь с запуском первых трех линий завода «Ямал СПГ» [12].

Суммарный объем реализации природного газа ПАО «НОВАТЭК», с учетом объемов реализованного сжиженного природного газа, составил 72,1 млрд м $^{3}$, что на $11 \%$ выше 2017 г. При этом на территории Российской Федерации в 2018 г. было реализовано 66,1 млрд м³ рынках - 6,1 млрд м ${ }^{3}$. Объем продаж природного газа в 2017 г. составил 0,1 млрд м $^{3}$, так как поставки сжиженного природного газа с проекта «Ямал СПГ» начались только 8 декабря 2017 г. 
Показатели деятельности ПАО «ЛУКОЙЛ», тыс. руб. [13]

\begin{tabular}{|l|c|c|c|c|c|c|}
\hline \multicolumn{1}{|c|}{ Показатель } & 2013 г. & 2014 г. & 2015 г. & 2016 г. & 2017 г. & 2018 г. \\
\hline Выручка & 260008509 & 242880237 & 259197748 & 316540706 & 223419650 & 264355247 \\
\hline Себестоимость & 19597275 & 17799989 & 21896068 & 18041817 & 19364531 & 20625229 \\
\hline Прибыль от продаж & 215773801 & 202901835 & 212970686 & 270792832 & 157746320 & 211379940 \\
\hline
\end{tabular}

За 2013-2018 гг. выручка увеличилась на 1,7 \%, себестоимость - на 5,3 $\%$, при этом прибыль от продаж снизилась на 2,0 \%.

Проведенный сравнительный анализ позволил сделать выводы, что на выручку предприятий нефтегазового комплекса оказывают влияние основные факторы, которые в обязательном порядке следует принимать к учету при разработке и реализации различных программных документов социальноэкономического развития регионов Севера и Арктики, в том числе $[14,15]$ :

- стабильность валютных курсов, что можно объяснить тем, что основные операции предприятиями осуществляются в российских рублях, а большая часть выручки от продажи формируется в долларах США или евровалюте;

- рыночные цены на сбываемую продукцию;

- тарифы естественных монополий, например, значительное влияние на деятельность ПАО «Газпром» и ПАО «НОВАТЭК» оказывает государственное регулирование ценообразования.

\section{2. Оценка инвестиционной привлекательности арктических предприятий нефтегазового сектора}

Мировой финансовый кризис 2008 г. привел к значительному снижению инвестиционной активности северных промышленных предприятий РФ. При анализе факторов риска в деятельности российских предприятий нефтегазового сектора инвесторы опасаются применять «игровой принцип», запрашивая более надежные аргументы финансовой привлекательности. В этой связи в последнее время возросла значимость исследований, связанных с разработкой надежных методов анализа привлекательности инвестиций в промышленные предприятия.

Следует отметить, что в литературных источниках понятие «инвестиционная привлекательность компании» имеет различные трактовки от прикладной узкопрофильной [16-19] до философски абстрактной [20, 21]. В рамках данной работы принято, что инвестиционная привлекательность предприятия представляет собой интегральную характеристику объектов, в отношении которых планируется вложение свободных средств с целью повышения эффективности использования активов с учетом их ликвидности, направлений развития и сбыта продукции, состояния платежеспособности, финансовой устойчивости [22].

Проведенные исследования показали, что инновационно-технологическое развитие предприятий связано с основным инвестиционным источником собственными средствами [23-29]. Следует отметить, что методиками не 
предусмотрен единый комплексный подход к оценке инвестиционной привлекательности [30-37], поэтому в конкретных случаях используется разнообразный набор финансовых коэффициентов функционирования предприятия. Наиболее распространенными являются такие частные методики, как:

- методика оценки с целью слияния / поглощения Д. А. Ендовицкого $[38,39]$;

- оценка инвестиционной привлекательности металлургической компании О. М. Мельничук [40];

- методика рейтинговой оценки Т. Ю. Салютиной и Л. С. Рабовской [41];

- анализ денежных средств О. А. Крейниной [42].

Используя сильные стороны указанных частных методик, авторы постарались сформировать интегральную методику оценки инвестиционной привлекательности, с помощью которой наиболее четко проявляются и однотипно сравниваются наиболее важные показатели деятельности компании. В качестве объективных фактографических данных используются материалы бухгалтерской и статистической отчетностей, представленные на открытых публичных сайтах корпоративной информации [43]. Расчет интегральных показателей тринадцати ведущих операторов нефтегазового комплекса Севера и Арктики за 2014-2018 гг. выполнен по следующей формуле:

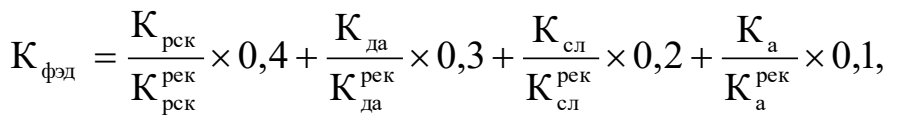

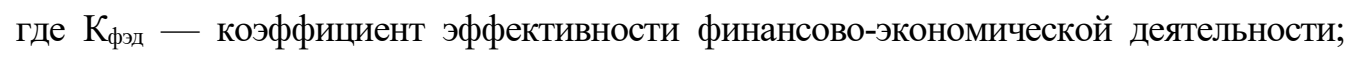
$\mathrm{K}_{\text {рск }}$ - коэффициент рентабельности собственного капитала; $\mathrm{K}_{\text {рск }}^{\text {рек }}$ - рекомендуемое значение рентабельности собственного капитала $(>0,2) ; K_{\text {да }}$ - коэффициент деловой активности; $K_{\text {да }}^{\text {рек }}$ - рекомендуемое значение коэффициента деловой активности $(>0,7) ; K_{\text {сл }}-$ коэффициент срочной ликвидности; $K_{\text {слл }}^{\text {рек }}-$ рекомендуемое значение коэффициента срочной ликвидности $(>0,7) ; K_{\mathrm{a}}-$ коэффициент автономии; $\mathrm{K}_{\mathrm{a}}^{\mathrm{pe \kappa}}-$ рекомендуемое значение коэффициента автономии $(>0,5)$.

На основании анализа интегральных показателей произведено ранжирование рассматриваемых предприятий по их инвестиционной привлекательности и выявлены тренды ее изменений во времени за шестилетний период (рис. 1).

Исследования показали, что к 2018 г. только шесть предприятий из тринадцати сохранили свой рейтинг неизменным: ПАО «Сургутнефтегаз» высокую инвестиционную привлекательность, ОАО «Севернефтегазпром», ПАО «НОВАТЭК» и АО «Мурманоблгаз» - умеренную привлекательность, АО «Сахатранснефтегаз» и ОАО «Тарманское западное» — низкую привлекательность.

$\mathrm{AO}$ «Алроса-Газ» и АО «Сибнефтегаз» понизили рейтинг и перешли из групп с высокой и умеренной привлекательностью в группы со средней и низкой.

Пять предприятий показали положительную тенденцию роста инвестиционной привлекательности. При этом ОАО «Варьеганнефть» продемонстрировало повышение инвестиционной привлекательности в 14 раз и с низов рейтингового ряда в 2018 г. перешло в группу с высокой привлекательностью. Это связано, прежде всего, с ростом выручки, чистой прибыли и, соответственно, с увеличением объема располагаемых предприятием финансовых средств. 


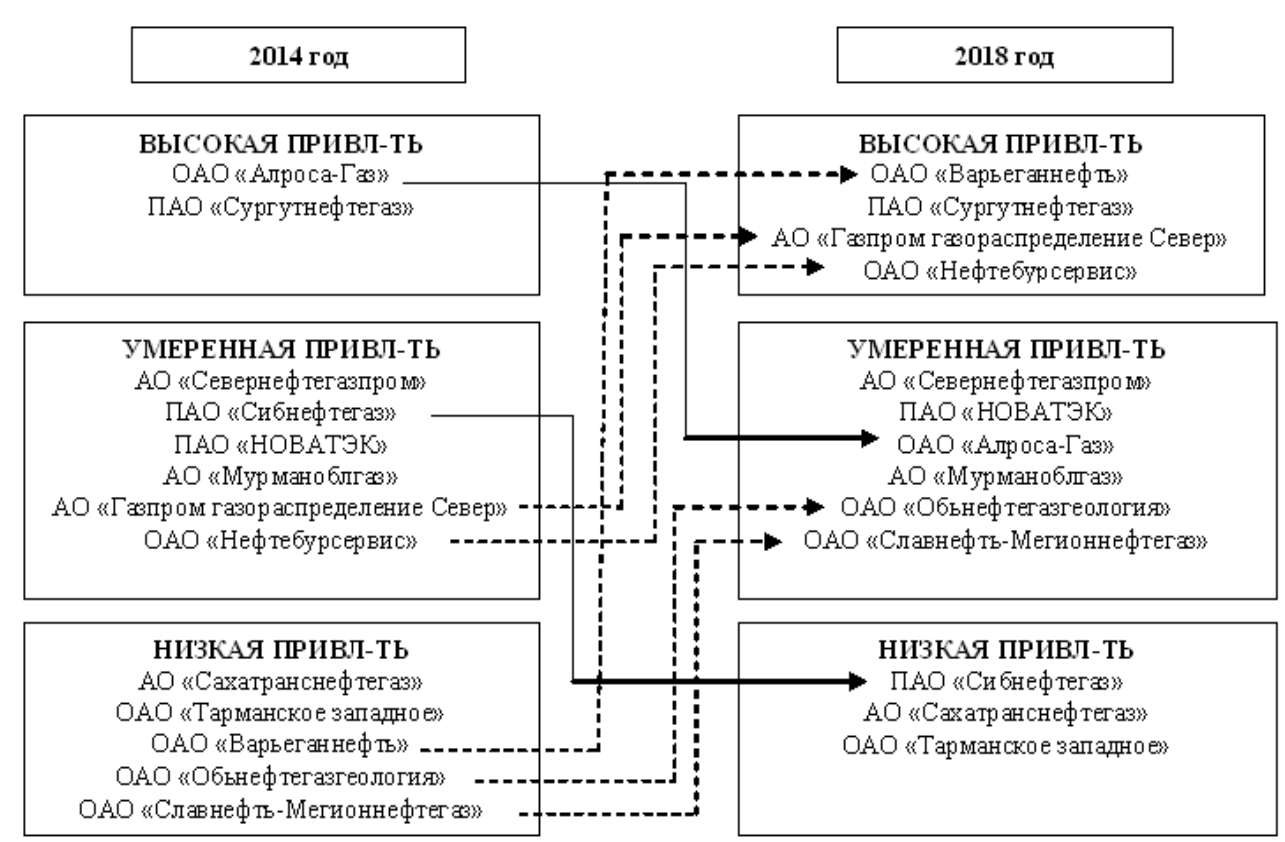

Составлено авторами по бухгалтерской отчетности предприятий

Рис. 1. Инвестиционная привлекательность северных предприятий нефтегазового комплекса

Таким образом, за рассматриваемый период большинство компаний не показали устойчивую инвестиционную привлекательность.

Интегральная методика и проведенное на ее основе ранжирование предприятий нефтегазового комплекса Севера и Арктики позволяет инвесторам получить дополнительную объективную информацию, способствующую принятию взвешенных решений в отношении участия в реализации инвестиционных проектов рассматриваемых компаний.

Требуется проведение дальнейших исследований по разработке научно обоснованных методических основ оценки инвестиционной привлекательности промышленных предприятий, особенно для специфических природных условий Севера и Арктики, а также в случаях влияния на перспективу геополитических факторов, включая санкционные режимы и соглашения по защите среды обитания.

\section{3. Движущие силы и риски грузопотоков углеводородного сырья на высокоширотных трассах Северного морского пути и Баренцева моря}

Арктика вступила в новую эпоху своего развития, перегруппировав пакет движущих сил и мотивацию обживания дискомфортных для жизни арктических территорий. Для снабжения индустриальных центров на арктическом побережье и Крайнем Севере России сформировалась система портов Северного морского пути (далее - СМП). Ситуация кардинально изменилась в начале XXI в., когда на фоне потепления климата в Арктике возникли предпосылки для круглогодичного судоходства с резким изменением структуры грузопотоков. 
К прогнозам развития гражданского сектора техносферы Арктики следует добавить ускоренное развитие инфраструктуры и арктических транспортных систем (далее - АТС), предусмотренных в национальных стратегиях всех приарктических государств [44].

Интенсификация освоения месторождений энергетического сырья в Арктической зоне Российской Федерации и повышение интереса $к$ использованию заполярной альтернативы «Шелковому пути», связывающему азиатские и европейские рынки, привели к быстрому росту объемов грузоперевозок по СМП и высокоширотным трассам Западной Арктики (рис. 2).

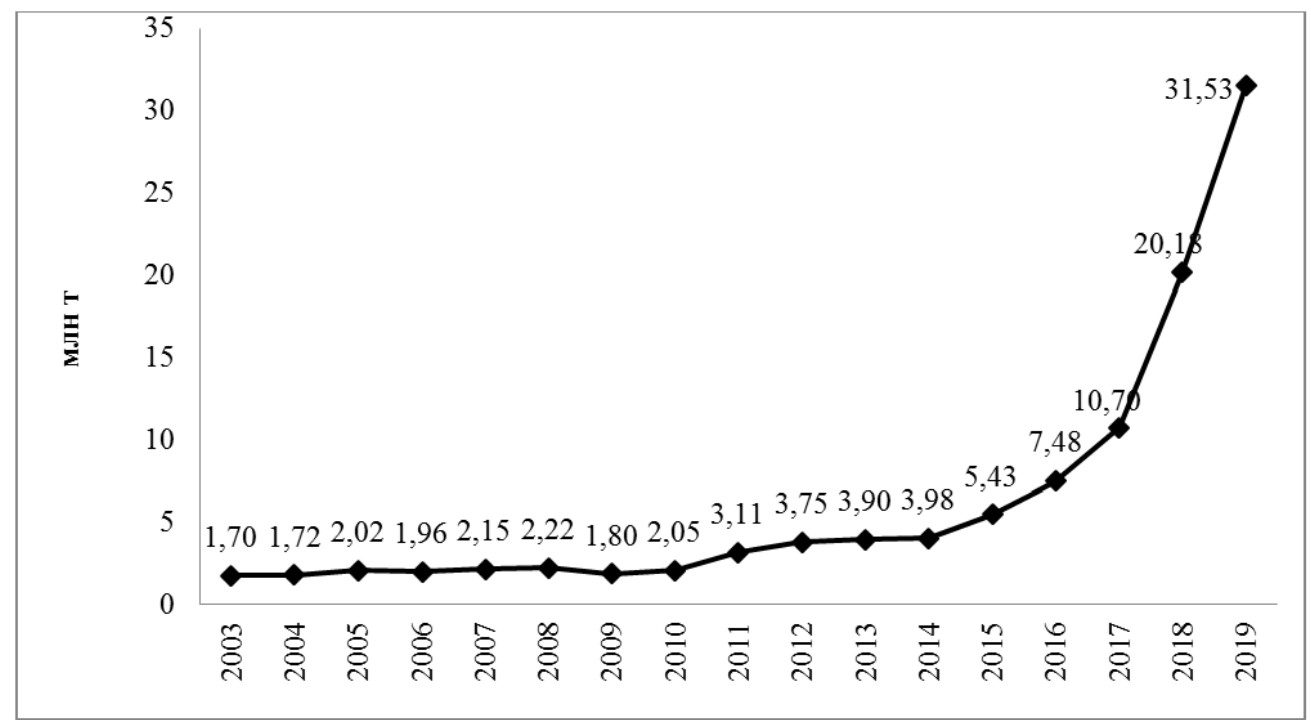

Составлено авторами по [45]

Рис. 2. Объем перевозок грузов в акватории Северного морского пути

В Стратегии развития Арктической зоны Российской Федерации и обеспечения национальной безопасности на период до 2020 года (Стратегия2013) [46] и в многочисленных выступлениях руководителей страны на международных арктических форумах подчеркивается, что пространственное развитие должно строиться на концепции планомерного обживания территории с формированием долговременных комфортабельных поселений, связанных между собой и «большой землей» надежными коммуникациями. Такой подход подразумевает обеспечение безопасности грузоперевозок с учетом специфики опасных природных явлений в Арктике, а также осуществление превентивных мероприятий для снижения аварийности на транспортных коридорах, по которым планируется перевозка десятков миллионов тонн нефтепродуктов, катастрофические разливы которых могут нанести природным экосистемам невосполнимый ущерб.

В настоящее время главной движущей силой в развитии экономики Арктики служат благоприятные условия для расширения российскими корпорациями своей ниши на мировом рынке энергетического сырья [47]. Экспорт нефти, газа и угля из России по традиционным транспортным 
коридорам достиг своего «потолка». Ухудшение геополитической обстановки резко усложнило строительство и эксплуатацию трубопроводных систем, связывающих сибирские регионы с европейским и азиатским рынками.

В этих условиях особую привлекательность приобретают природносырьевые источники Арктики, локализованные вблизи побережий, на которых имеется возможность в короткие сроки построить глубоководные порты.

Во-первых, такой стратегический маневр снижает напряженность в сложных переговорах по развитию транспортных систем на суше, в акваториях Балтийского и Черного морей. Во-вторых, расширение перевозок по свободным от «геополитических» ограничений арктическим трассам дает возможность гарантированно выполнять обязательства по долгосрочным контрактам на поставку энергетических ресурсов зарубежным потребителям, а также активнее участвовать в спотовой торговле. Убедительным примером для понимания значимости последнего фактора может служить поразившая весь мир в декабре 2017 г. спотовая поставка СПГ с завода «Ямал СПГ» российской компании ПАО «НОВАТЭК» на атлантическое побережье США, где из-за сильнейших морозов возник непредвиденный дефицит топлива и цены на него увеличились в десятки раз [48].

В-третьих, те компании, которые решаются организовать добычу и экспорт энергетических ресурсов на побережье Арктики с использованием собственных портовых терминалов и транспортных судов, выходят из-под контроля «естественных монополистов» ОАО «РЖД», ПАО «Транснефть» и ПАО «Газпром», что в перспективе обеспечивает им независимость и конкурентоспособность. Для мотивации бизнес-активности этот фактор имеет в определенных случаях первостепенное значение, о чем свидетельствует опыт компании УК «Востокуголь», организовавшей в 2015 г. освоение Таймырского угольного бассейна с одновременным строительством портов «Чайка» и «Север» вблизи поселка Диксон [49].

В государственных стратегических документах целевые параметры развития АТС пока не определены, поэтому для оценки реальных объемов грузопотоков ориентироваться следует на экспертные оценки. Поскольку головным оператором на трассах СМП является ФГУП «Атомфлот», то наиболее полную картину среднесрочной перспективы (до 2035 г.) дает обзор заключенных им соглашений и договоров с горнопромышленными и нефтегазовыми корпорациями. Согласно прогнозу начальника штаба морских операций ФГУП «Атомфлот» В. Г. Арутюняна, общий объем грузоперевозок по СМП поднимется с 10 млн т в 2017 г. до 40 млн т в 2024 г., а затем до 80 млн т в 2029 г. (без учета перевозок по заказам Минообороны РФ, в которых задействованы боле 80 судов торгового флота, и транзитных рейсов контейнеровозов) [50]. Основными заказчиками услуг ФГУП «Атомфлот» в этот период будут горнорудные и нефтегазовые корпорации, в инвестиционные планы которых включена реализация пятнадцати мегапроектов по выведению на международные рынки сырой нефти, сжиженного природного газа, антрацитов и цветных металлов из месторождений Ямала, Таймыра и Новой Земли. По прогнозу Минприроды РФ, обнародованному в ноябре 2019 г., общий объем перевозок минерально-сырьевой продукции по СМП может достичь 140 млн т в год.

По состоянию на 2019 г. в гражданском секторе грузопотоков на арктических трассах формируется восемь наиболее крупных проектов. 
1. «Ямал СПГ» - освоение ресурсов Южно-Тамбейского газоконденсатного месторождения с производством до 17 млн т в год сжиженного природного газа и вывозом его на экспорт через портовый терминал «Сабетта» в Обской губе Карского моря на рынки ЕС и юго-восточной Азии (ЮВА) в период 2017-2040 гг. Проект включает формирование собственного флота из шестнадцати супертанкеров-газовозов нового типа Yamalmax, усиленного ледового класса Arc7 водоизмещением до 140 тыс. т, пяти вспомогательных судов портового флота, а также использование услуг от четырех до восьми ледоколов ФГУП «Атомфлот» для гарантированной круглогодичной проводки газовозов в тяжелых ледовых условиях. Ожидаемый объем транспортировки сжиженного природного газа по арктическим трассам в 2023-2038 гг. - 17, 6 млн т в год [50].

2. «Арктик СПГ-2» - освоение ресурсов нефтегазоконденсатных месторождений Гыданского полуострова с производством до 19,8 млн т в год сжиженного природного газа и вывозом его из Обской губы на рынки ЕС и ЮВА в период 2023-2040 гг. При благоприятной конъюнктуре ПАО «НОВАТЭК» планирует создать арктический кластер, который обеспечит грузопотоки по СМП до 57 млн т к 2030 г. с повышением до 70 млн т в последующее десятилетие [51].

3. «Новый порт - Ворота Арктики» - освоение нефтяных месторождений западного побережья Обской губы с круглогодичным вывозом сырой нефти через уникальный морской терминал «Ворота Арктики» в объеме от 6,3 млн т в 2018 г. до 8,5 млн т в последующие годы [50].

4. «Нефтяной терминал “Таналау”» - освоение Пайяхской группы нефтяных месторождений на Таймыре с локализацией грузового терминала в устье Енисея с грузооборотом 3,8 млн т в 2018 г. и его ростом до 5 млн т в год в последующий период [50].

5. «Месторождение Приразломное» - освоение нефтяных ресурсов с использованием морской ледостойкой стационарной платформы «Приразломная» и круглогодичным вывозом нефти марки ARCO в г. Мурманск крупнотоннажными танкерами ледового класса водоизмещением 70000 т [52].

6. «ВостокУголь» - освоение Таймырского угольного бассейна со строительством в районе поселка Диксон в устье Енисея двух глубоководных портовых терминалов «Чайка» и «Север» для вывоза антрацита на рынки ЕС и ЮВА; планируемый объем грузооборота по обоим терминалам 20 млн т в год с возможным ростом до 30 млн т [49].

7. «Транспортное обеспечение деятельности горно-металлургической компании «ПАО “Норильский никель”» - круглогодичный вывоз готовой продукции в объеме 1,3 млн т и доставка необходимого технологического оборудования и продуктов через порт Дудинка в низовьях р. Енисей [50].

8. «Павловское месторождение» - освоение и вывоз рудных концентратов в объеме 0,3 млн т в год и доставка технологического оборудования и продуктов на Павловский ГОК в 2019-2030 гг.[53].

Дополнительным потенциалом для наращивания грузоперевозок по арктическим морским трассам является система транзитных контейнерных перевозок, однако их конкурентоспособность все еще остается предметом острых дискуссий $[54,55]$. 
Интенсивность судоходства по арктическим морским трассам скачкообразно возрастает в современный период, и этот тренд (даже без учета транзитных контейнерных перевозок и транспортного обеспечения деятельности Минобороны РФ) к середине 2020-х гг. может вывести уровень трафика до 1500-2000 судопроходов в год с доминирующей ролью «большегрузов» водоизмещением от 70 до 160 тыс. т. Реальность этого тренда определяется долгосрочными планами бизнесактивности операторов индустриальных проектов.

К сожалению, на этом прогрессивном пути развития Арктики, в полной мере отвечающем национальным интересам, декларированным в Стратегии развития Арктической зоны Российской Федерации и обеспечения национальной безопасности на период до 2020 года [46], складывается неблагоприятная ситуация с обеспечением промышленной и экологической безопасности [56].

За формирование технической инфраструктуры и институциональное обустройство систем безопасности на транспортных коридорах Арктики несет ответственность государство, однако правительственные органы проявляют неоправданную пассивность в решении даже тех приоритетных задач, которые включены в план реализации утвержденной Стратегии-2013. Негативным последствием такой ситуации является отставание России в навигационном обустройстве транспортной системы Арктики и контроле гидрометеорологической и геодинамической обстановки в зонах промышленного освоения и на морских судоходных трассах.

В средних широтах в управлении судоходством на океанических трассах широко используются интернациональные центры ситуационного космического мониторинга типа MarineTraffic, ShipFinder, Victoria, дающие возможность в режиме реального времени получать оперативную информацию о местоположении судна, его маршруте. Полноценную гидрометеорологическую информацию и прогнозы динамики океанических условий и ледовитости океанов и европейских морей с 2015 г. предоставляет зарубежным пользователям созданное по инициативе ЕС агентство CMEMS (The Copernicus Marine Environmental Monitoring Service), располагающее космическими мониторинговыми системами дистанционного зондирования земли (Д33) и сетью наземных обрабатывающих и прогнозных центров [57]. В дополнение к этому агентству в Евро-Арктическом регионе на архипелаге Шпицберген под эгидой Норвегии с 2018 г. осуществляется интернациональный проект "Svalbard Integrated Arctic Earth Observing System" (SIOS), существенно улучшающий детальность освещения гидрометеорологической и экологической обстановки в Западной Арктике [58].

На подготовительной стадии в 2010-2014 гг. в обосновании проекта принимали участие российские научные учреждения (Кольский научный центр, Геофизическая служба РАН и ААНИИ Росгидромета), однако ухудшение геополитической ситуации и финансового положения российского научного центра на архипелаге Шпицберген лишили Россию возможности продолжить участие в Консорциуме SIOS, объединяющим двадцать пять научных центров из десяти европейских стран. По тем же причинам и вследствие ужесточения санкционного режима в отношении поставок в Россию высокотехнологического оборудования для арктических исследований не выполняются плановые задания по формированию национальной мониторинговой системы на базе космической группировки спутников типа «Арктика» $[59,60]$. 
Из-за недостатка финансовых средств в 2014 г. были остановлены работы по реализации принятой правительством РФ в 2011 г. федеральной целевой программы «Снижение рисков и смягчение последствий чрезвычайных ситуаций природного и техногенного характера в Российской Федерации до 2015 года», в рамках которой планировалось создать на островах и побережье Баренцева и Карского морей наземный комплекс Арктической системы геофизического мониторинга опасных динамических процессов в природной среде и техносфере, что могло вывести Россию в лидеры по научнотехническому обеспечению промышленной безопасности в морехозяйственном секторе Арктики [61, 62].

Критический анализ сложившейся ситуации, выполненный в 2017 г. экспертами РАН и Росгидромета, показал, что даже вся существующая совокупность международных и российских национальных систем мониторинга морского транспорта и информационной поддержки безопасности судовождения в Арктике не обеспечивает возросших потребностей морехозяйственной деятельности: «Информация о местоположении морских судов, передаваемая в режиме реального времени, обрывается примерно в районе Баренцева моря. Имеются лишь локальные «пятна» информации в Белом море за счет ведомственных источников, например, системы освещения обстановки ВМФ» [56].

На морских транспортных коридорах Арктики по причине отсутствия источников бесперебойного питания и устойчивой связи (сотовой или космической) не сформирована система автоматической идентификации судов, а эффективность применения традиционных радиолокационных систем для контроля судоходства и выявления опасных природных явлений сильно понижена вследствие специфической геофизической среды и климатических условий Арктики. Гидроакустические системы мониторинга традиционно находятся в ведении оборонного комплекса, и до последнего времени не предпринималось никаких попыток их двойного применения для гражданских целей, хотя научно обоснованные предпосылки для такого инновационного подхода с применением современных технических средств на основе волоконнооптических донных систем сейсмоакустического мониторинга имеются $[56,63]$.

Приходится констатировать, что практически единственным доступным для широкого круга пользователей АТC агентством, предоставляющим оперативную информацию о навигационной обстановке в российской части Арктики, является центр ЕСИМО (Единой государственной системы освещения обстановки в Мировом океане) при НИИ Арктики и Антарктики Росгидромета [64]. ЕСИМО еженедельно размещает на своем интернет-сайте мелкомасштабные обзорные карты ледовой обстановки в Арктическом бассейне и прогностические модели эволюции ледовитости Баренцева моря с заблаговременностью прогноза семь суток. Санкции западных стран существенно ограничивают возможности использования ЕСИМО комплексных данных Д3З европейских и американских космических агентств, а опора на данные оптических систем российских спутников серий «Метеор-М» и «Канопус-В» не дает возможности удовлетворить все потребности пользователей национальной системы мониторинга Арктики и трасс СМП [56].

Особо следует отметить, что ни ЕСИМО, ни какая-либо иная российская мониторинговая система не предоставляет информации об айсберговой опасности на 
трассах СМП и «открытого моря» в баренцевоморской части Арктического транспортного коридора. До начала «большого скачка» в объемах грузоперевозок по глубоководным арктическим маршрутам, проходящим через пролив между покрытыми ледниками архипелагами Земля Франца-Иосифа и Новая Земля и огибающим Северную Землю и Новосибирские острова, увенчанные ледовыми шапками, риск столкновения судов с айсбергами оценивался на уровне 1-2\%, однако после выхода на высокоширотные трассы в условиях аномального растепления Арктики супертанкеров риск аварийных столкновений многократно возрос (рис. 3,4$)$.

Следует признать риски, на которые идут операторы арктических перевозок, организующие рекордные по скорости рейсы «большегрузов» через потенциально опасные акватории с высоким уровнем айсберговой опасности. Сто лет назад такие гонки через «Аллею айсбергов» на трансатлантической трассе из Европы в Америку привели к гибели «Титаника», суперлайнера того времени, значительно уступающего по грузоподъемности и скорости современным арктическим «большегрузам». Это послужило толчком к экстренной организации в опасном районе интернационального «айсбергового патруля», успешно действующего до сих пор [65].

Очевидно, что для развития трансарктических грузопотоков через российскую часть Арктики необходимо принять меры по формированию аналогичного патруля в Карско-Баренцевоморском секторе высокоширотной трансарктической магистрали. Эта задача технически и методологически более сложная, чем патрулирование крупных айсбергов столового типа в Северной Атлантике, она потребует интеграции наземно-космических систем ДЗ3 [66] с инновационными сейсмоакустическими комплексами геофизического мониторинга, разработанными в последние годы в ФИЦ ЕГС РАН $[62,63]$.

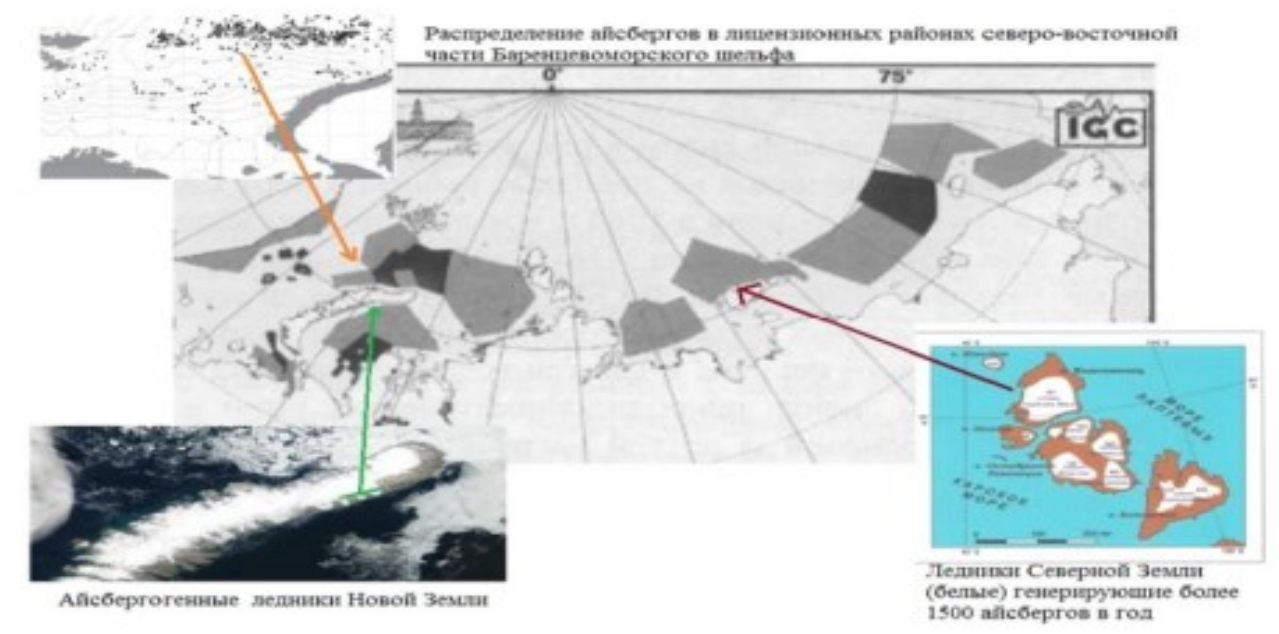

Рис. 3. Айсбергогенные ледники арктических архипелагов западного сектора Арктической зоны РФ, провоцирующие в периоды аномального потепления климата «айсберговые атаки» на трансарктические транспортные коридоры и оффшорные промысловые поля на шельфе Арктической зоны РФ (по [67, 68]) 


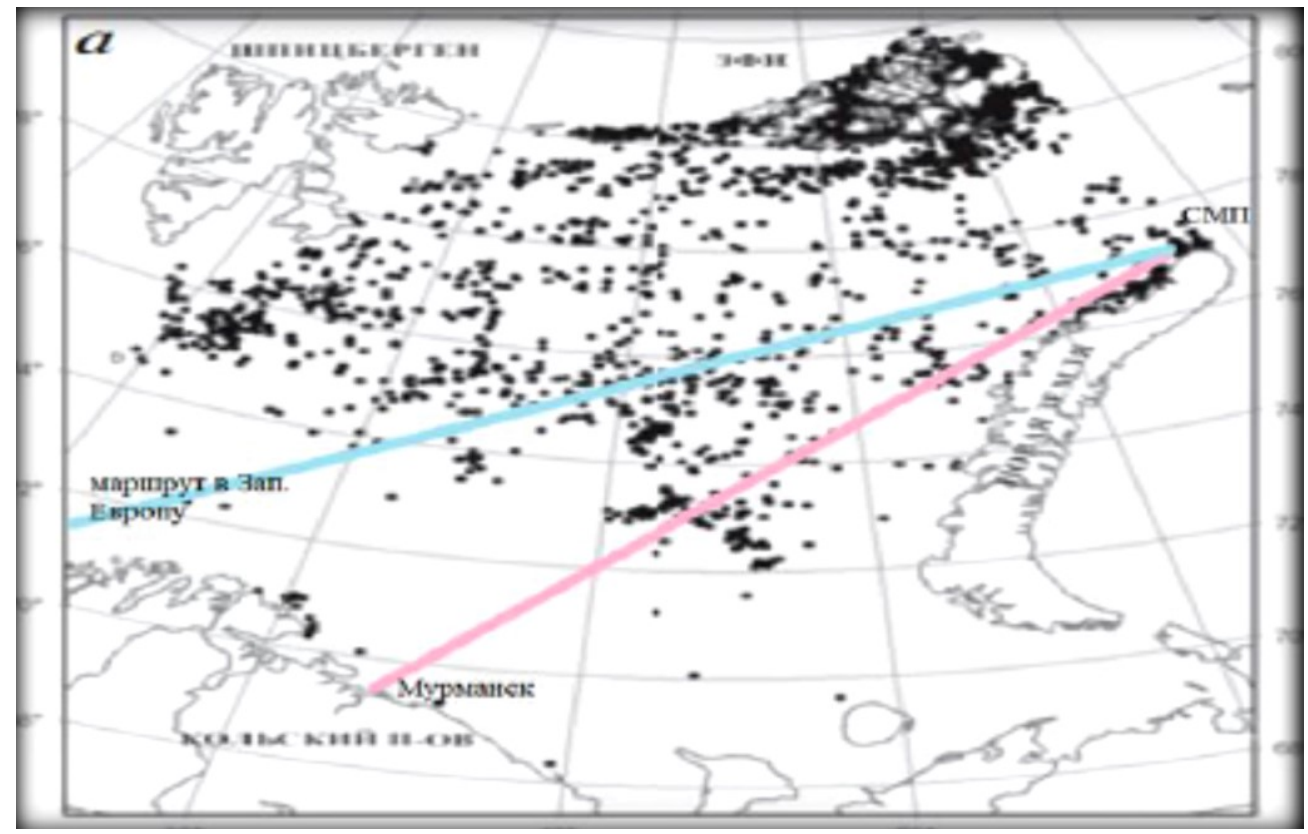

Рис. 4. Распределение айсбергов на морских коммуникациях Баренцева моря, связывающих северную трассу СМП с портами Западной Европы (синяя линия) и Мурманском (красная линия) (по [67, 69])

Помимо очевидной айсберговой опасности на трансарктических маршрутах, проходящих над относительно мелководными участками шельфа (с глубинами менее 100 м), значительным фактором риска являются флюидодинамические процессы в блоках субаквальной вечной мерзлоты, подвергающихся разрушению вследствие снятия ледниковой нагрузки и потепления климата [70, 71].

Отнесение этой группы деструктивных процессов в недрах шельфа арктических морей к числу «больших вызовов», сдерживающих экономическое развитие Арктики, произошло лишь в последние годы, поэтому поиск адекватных технологий для контроля и управления этим фактором риска находится пока на начальной стадии. В то же время средства массовой информации в течение десятилетия внедряют в сознание общественности утрированное представление о катастрофических последствиях взрывов «метановых бомб», заложенных природой в слой вечной мерзлоты в ледниковый период, что неизбежно влияет на оценку «страховых рисков» и служит поводом для завышения тарифов или отказа в страховании грузов. Для нормализации ситуации и разработки реалистичных превентивных мер необходима целевая государственная поддержка научных исследований, направленных на изучение масштабов и механизмов разрушения криолитосферы под воздействием потепления климата и роста техногенного стресса [71].

Среди стран, конкурирующих с Россией в освоении сырьевых ресурсов Арктики, наиболее полноценные базы данных и знаний сформировала Норвегия, которая первая среди приарктических государств создала специализированный 
Центр изучения арктических газовых гидратов, природной среды и климата при Арктическом университете в Тромсе [72]. В России инициатором формирования аналогичной по направленности целевой программы и межведомственного исследовательского консорциума выступила в 2018 г. Российская академия наук, предложившая в 2019-2021 гг. силами РАН, госкорпорации «Роскосмос» и Министерства науки и высшего образования осуществить проект ориентированных фундаментальных исследований и поисковых разработок «Взаимодействие литосферы, криосферы и атмосферы в Арктике в контексте изучения геодинамических и флюидогазодинамических процессов с использованием сети береговых и донных сейсмических станций и сейсмоинфразвуковых комплексов, а также аэрокосмического мониторинга».

Из всего вышеизложенного следует, что современное состояние мониторинговых систем и институциональной инфраструктуры освещения обстановки в Северном Ледовитом океане не обеспечивает актуальные потребности развивающегося ускоренными темпами транспортного сектора экономики Арктики в оперативном получении полноценной информации о навигационных и гидрометеорологических условиях судовождения на трансарктических морских трассах. Россия отстает от конкурирующих с ней приарктических государств в формировании современных систем наземнокосмического контроля состояния природной среды в Арктике. Необходимо принять срочные меры по организации «айсбергового патруля» на высокоширотных трассах трансарктических транспортных коридоров и по развитию научно-методических основ контроля и предотвращения рисков, связанных с проявлениями опасных флюидодинамических процессов в криолитосферном слое арктического шельфа. Без ускоренной реализации целевых программ по обеспечению транспортных коридоров надежными системами предупреждения о возникновении опасных районов с повышенной концентрацией айсбергов, аномальных восходящих потоков метана и проявлений грязевого вулканизма, изменяющего морфологию дна на морских трассах, бессмысленно рассуждать о перспективах превращения СМП в «Ледовый шелковый путь», способный составить конкуренцию традиционному Южному морскому коридору между рынками ЕС и ЮВА. Для обеспечения экологической безопасности на трансарктических трассах целесообразно расширение интернациональной кооперации при осуществлении дистанционного мониторинга опасных ситуаций и организации спасательных работ в Арктике.

\section{4. Освоение нефтегазовых месторождений и природоохранная деятельность северных территорий}

Ресурсно-сырьевой сектор России в преобладающей степени расположен в северных и арктических регионах. Север и Арктика, как одни из главных минерально-сырьевых поставщиков, удовлетворяющих внутренние потребности и поддерживающие экспортный потенциал России, в перспективе сохранят специализацию на добыче и переработке природных ресурсов [73].

В современных условиях освоение природных ресурсов перестало быть «простым» в технологическом отношении. Освоение шельфовых месторождений осуществляется $\mathrm{c}$ помощью инновационных проектов. 
$\mathrm{C}$ каждым годом продукты становятся все в большей степени наукоемкими с повышенной добавленной стоимостью. Однако при этом важнейшим вопросом остается сохранение окружающей среды.

Совершенствование государственной политики и государственного регулирования освоенческих процессов на Севере и в Арктике должно быть нацелено на разработку и реализацию пятого и шестого технологических укладов и соответствующего инструментария стимулирования операторов развивающих проектов. Еще одна серьезная проблема связана с разработкой методологических подходов к улучшению деятельности в сфере охраны окружающей среды северных территорий с целью устойчивого экологического и экономического развития с обязательным исполнением международных обязательств по сохранению экологического равновесия [74, 75].

Роль государства в отношении освоения нефтегазовых месторождений должна быть направлена на оценку ресурсов и определение методов их рационального освоения. Правовая основа для реализации функций государства определяется соответствующим законодательством.

Основные проблемы, связанные с природоохранной деятельностью северных регионов:

- сокращение разведанных запасов минерального сырья и недостаточно эффективное использование природных ресурсов;

- неудовлетворительное состояние основных фондов и высокая степень износа технологического оборудования горных предприятий;

- недостаток финансовых ресурсов;

- несовершенство инновационной инфраструктуры;

- низкая эффективность государственного регулирования;

- отсутствие современной системы переподготовки и повышения квалификации кадров;

- недостаточная реализация энергосберегающих технологий;

- отсутствие мотивации для реализации инновационных проектов, обеспечивающих сокращение вредного воздействия промышленных отходов на среду обитания.

О возможности регулирования природоохранной деятельности на Севере свидетельствует опыт осуществления инновационных подходов к освоению природных ресурсов ведущими приарктическими странами, такими как Норвегия, Канада, США, Финляндия. Они используют минерально-сырьевой сектор в качестве катализатора формирования современных технологических комплексов, повышения научно-технического уровня, подготовки высококвалифицированных специалистов [76].

Промышленные предприятия, осваивающие месторождения Севера и Арктики, в том числе на шельфе, оказывают значительное влияние на окружающую природную среду, что ведет к значительным нарушениям водной и земной поверхности. Для сохранения биоразнообразия и восстановления нарушенных земель, а также для реабилитации подвергшихся техногенному стрессу экосистем необходимо регулярно и последовательно проводить целенаправленные природоохранные мероприятия в течение всего жизненного цикла предприятия, в том числе после завершения активной фазы добычи и переработки природного сырья [77]. 
Природоохранную деятельность ресурсных предприятий северных регионов далеко не всегда можно отнести к категории инновационной и всеобъемлющей, т. е. гарантирующей соблюдение экологического императива [78, 79]. К типичным недостаткам можно отнести: игнорирование экологического аудита, отсутствие четкой и понятной системы платежей и штрафов за загрязнение природной среды; неэффективность механизма стимулирования разработки и внедрения инновационных технологий, слабый контроль за соблюдением правил и требований природопользования.

У операторов ресурсных проектов, в подавляющем большинстве случаев это представители «новой волны» пришлого населения, восприятие природы в целом ограничивается, как правило, представлениями о ней как об объекте технического воздействия, а нравственно-эстетическое отношение к среде обитания отсутствует. Им недостает полноценного экологического образования, которое следует понимать как непрерывный процесс обучения, воспитания и развития личности, направленный на формирование экологической культуры и моральной ответственности. Главная задача и цель экологического воспитания - формирование у человека ценностей, связанных с осознанием приоритетности задач сохранения и охраны здоровой среды обитания человека. Правовой статус охраны окружающей среды не должен допускать реализацию экологических проектов, ухудшающих экологическое равновесие, независимо от потенциальной прибыли при их реализации [80].

Экологическое воспитание должно включать бережное отношение человека к природе, способствовать раскрытию эстетического, познавательного, оздоровительного, практического значения природы в жизни людей.

Вопросы экологии тесно переплетаются с вопросами моральных принципов и общей культуры человека. Экологическое воспитание, наряду с экономическим и правовым, должно стать основой выживания человечества, становления нового образа жизни, фундаментом экологического мировоззрения.

Экологическое воспитание предполагает: воспитание);

- воспитание гуманного отношения к природе (нравственное

- формирование системы экологических знаний и представлений (интеллектуальное развитие);

- развитие эстетических чувств (умения увидеть и прочувствовать красоту природы, восхититься ею, желания сохранить ее);

- участие детей в посильной для них деятельности по уходу за растениями и животными, по охране и защите природы.

Все составляющие подобного комплексного подхода к экологическому воспитанию населения должны осуществляться не обособленно, а взаимосвязано, в том числе с учетом следующих основных требований:

- повышения экологической культуры и соответствующего просвещения;

- создания постоянно действующей системы экологического образования;

- организации профессиональной переподготовки и повышения квалификации руководителей организаций, отвечающих за принятие 
соответствующих решений в области охраны окружающей среды и обеспечения экологической безопасности;

- распространения экологических знаний;

- привлечения населения к участию в мероприятиях по улучшению и охране окружающей среды.

На базе дошкольных образовательных учреждений должны проводиться занятия с использованием инновационных программ и методик по экологическому образованию детей: выставки рисунков и поделок из природных материалов, праздники. В общеобразовательных учреждениях и в центрах дополнительного образования детей также предусмотрено проведение тематических уроков, конференций и экскурсий.

На примере Мурманской области можно показать, что форматы воспитательных мероприятий могут быть самыми разными. Так, одним из наиболее ярких и эффективных событий в 2017 г. стал педагогический форум «От экологического образования - к экологической культуре», проведенный 28 февраля в рамках общероссийских программ «Год экологии» и «Год особо охраняемых природных территорий», утвержденных распоряжением правительства от 26 декабря 2016 г. № 318-РП. В форуме приняли участие преподаватели Мурманского арктического государственного университета, научные сотрудники Мурманского областного краеведческого музея, представители средств массовой информации, общественных и научных природоохранных организаций [81].

Наиболее широкий охват различных возрастных групп населения в Мурманской области обеспечили региональные этапы всероссийских мероприятий по государственной поддержке талантливой молодежи в рамках национального проекта «Образование» [82]:

- научная эколого-биологическая олимпиада обучающихся учреждений дополнительного образования детей;

- конкурс юных исследователей окружающей среды;

- юниорский лесной конкурс «Подросток»;

- олимпиада научно-исследовательских проектов детей и молодежи по проблемам защиты окружающей среды «Человек - Земля — Космос»;

- конкурс «Моя малая Родина: природа, культура, этнос»;

- конкурс исследовательских краеведческих работ обучающихся «Отечество»;

- конкурс «Юннат»;

- Российский национальный юниорский водный конкурс;

- геологическая олимпиада школьников.

Для дальнейшего повышения эффективности природоохранной деятельности северных регионов можно рекомендовать следующие направления организационной и образовательной деятельности:

- совершенствование законодательной базы; фирмами;

- активизация интеграционных процессов, в том числе с зарубежными

- повышение эффективности рационального комплексного освоения минерального сырья;

- ускорение перехода на пятый и шестой технологические уклады; 
- обновление основных фондов;

- создание необходимых инфраструктурных объектов;

- модернизацию системы подготовки и переподготовки кадров;

- увеличение количества реализуемых программ экологобиологической направленности;

- развитие учебно-опытных участков для организации практических занятий экологического воспитания детей; обеспечения;

- совершенствование системы информационно-коммуникационного

- решение комплекса проблем загрязнения природной среды;

- эффективное управление энергоснабжением и энергосбережением.

Необходимы дальнейшие научные разработки и практические рекомендации по регулированию природоохранной деятельности в условиях освоения нефтегазовых месторождений северных территорий. 


\section{2. ИННОВАЦИОННЫЕ ПОДХОДЫ К ОСВОЕНИЮ АРКТИЧЕСКОГО ШЕЛЬФА}

\section{1. Инновационное освоение арктического шельфа: проблемы, безопасность, перспективы}

В Основах государственной политики Российской Федерации в Арктике на период до 2020 года и дальнейшую перспективу (утвержденных президентом Российской Федерации 18 сентября 2008 г. Пр-1969) настойчиво декларируется целевая установка, согласно которой освоение углеводородного потенциала Арктической зоны является важнейшей геостратегической задачей России в первой половине XXI в.

Решению этой задачи в значительной мере препятствует введение западными державами (естественными конкурентами России в освоении природных богатств Арктики) неоправданных экономических санкций, потребовавших существенного изменения как внутренней структуры российской экономики, так и направленности векторов интеграции Российской Федерации в систему международных сырьевых и технологических рынков. Вследствие вынужденной переориентации страны на иные торговые отношения с новыми партнерами во второй декаде века начали складываться благоприятные условия для усиления кооперации России со странами Латинской Америки, Восточной Азии и бывшего СССР [83].

Ресурсные корпорации ПАО «НК “Роснефть”», ПАО «НОВАТЭК» и ПАО «Газпром» в перспективе рассматривают необходимость переориентации в направлении азиатского рынка инновационных технологий и соответствующего оборудования. Корпорации считают, что в этом случае может быть использован имеющийся потенциал [84]:

- Южной Кореи, представленной нефтяными и сервисными компаниями Daewoo, Kwang Shin и LHE;

- Индии, представленной компанией Indore Composite;

- Китая, представленного компаниями CNPC, Huawei, China National Logging Corporation, Shanghai Electric Heavy Industry.

Анализ сложившейся в настоящее время геополитической ситуации [85] показал, что с учетом смены партнеров в условиях продолжающегося режима санкций освоение арктических месторождений России следует осуществлять по следующим направлениям:

- разработка инновационных технологий отработки, транспортировки и дальнейшей переработки углеводородных ресурсов, а также организационноэкономическое и техническое сопровождение проектов;

- создание рациональных технологий по комплексному освоению минерального сырья, предусматривающему повышение конкурентного уровня развития горнопромышленного, химического и металлургического комплексов, в том числе формирование и поддержание госрезерва стратегических материалов;

- создание зон опережающего развития для импортозамещения и повышения конкурентоспособности ресурсных отраслей и комплексов;

- активизация развития отечественного машиностроения, в том числе судостроения, для обеспечения освоения природного сырья северных регионов; 
- создание технологического оборудования для работы в суровых условиях Арктики;

- разработка технологий для освоения месторождений, находящихся на значительных глубинах и удаленности от береговой линии;

- совершенствование системы материально-технического и энергетического обеспечения предприятий и логистических центров;

- развитие систем дистанционного мониторинга состояния природной среды и технологий предотвращения экологических рисков;

- полноценное обеспечение развивающих проектов высококвалифицированными кадрами, адаптированными к работе в арктических условиях;

- совершенствование транспортной инфраструктуры и систем связи;

- совершенствование системы спасательных работ и экстренной эвакуации людей.

Министр энергетики РФ Александр Новак в интервью S\&P Global Platts отметил, что «общий объём добычи на российских арктических проектах составляет 1,8 млн баррелей в сутки, в то же время в условиях текущих цен наблюдается снижение активности по шельфовым проектам». Кроме того, он сообщил, что российские предприятия, несмотря на санкционные ограничения и сложности сотрудничества с западными компаниями по реализации арктических проектов, продолжают проведение геолого-разведочных работ [86].

По мнению экспертов наиболее конкурентоспособной технологией освоения месторождений в Арктике является применение подводных способов, сочетающих плавучие и стационарные платформы или полностью автономные комплексы. При этом эксперты отмечают, что освоение арктических месторождений на шельфе потребует разработки более эффективного оборудования для буровых скважин, рассчитанного на круглогодичную эксплуатацию и автономную работу в экстремальных условиях [15].

Сегодня опыт работы на арктическом шельфе в полной мере нарабатывается лишь в ходе осуществления пилотного проекта ПАО «Газпром нефть» по освоению нефтяного месторождения Приразломное на шельфе Печорского моря. Многоцелевая ледовая стационарная платформа (МЛСП) «Приразломная» является уникальным техническим объектом, провозвестником эры супертяжелых гравитационных платформ, на основе которых планируется формировать добычные комплексы на мелководном шельфе центрального сектора Арктической зоны РФ. МЛСП «Приразломная» обеспечивает выполнение технологических операций, в том числе бурение эксплуатационных скважин, добычу нефти, ее хранение, подготовку и отгрузку. Функционирование платформы должно предусматривать эксплуатацию в арктических условиях, противостояние максимальным ледовым нагрузкам, а также отвечать требованиям безопасности. Небольшая глубина моря в районе платформы позволила установить ее непосредственно на дне. Бурение происходит внутри платформы. Ее основание является необходимой преградой между открытым морем и скважиной. Круглосуточный контроль за состоянием платформы обеспечивается специальной системой, состоящей из необходимых датчиков, реагирующих на нестандартные ситуации [87].

Продолжается работа по подготовке к эксплуатации Штокмановского газоконденсатного месторождения. Разработана принципиальная схема 
освоения месторождения, предусматривающая систему внутрипромысловых трубопроводов и морских бурильных колонн (райзеров), которые соединяют добывающее судно и подводный комплекс. На технологическом судне планируется расположение необходимого оборудования, в том числе компрессоров, электростанций, жилых помещений. Природный газ по двухниточному трубопроводу с судна будет передаваться на береговой завод для производства сжиженного газа [88].

Особое значение должно придаваться формированию инновационной политики освоения шельфовых месторождений Арктики, которая должна предусматривать целый комплекс разработок, направленных на содействие эксплуатации арктического шельфа на основе новых научных знаний и новейших технологий функционирования морских платформ в экстремальных северных условиях с учетом обеспечения безопасности персонала и исключения загрязнения окружающей среды. В этой ситуации особенно важны проектные решения, основанные на новейших научных разработках. Необходимо предусмотреть создание прочной конструкции морских платформ на основе новейших материалов. К таким конструкциям должен предъявляться целый комплекс требований, необходимых для эксплуатации в суровых климатических условиях. Эти вопросы были рассмотрены при реализации международного проекта «Баренц - 2020» для подготовки международных стандартов для безопасной разведки, добычи и транспортировки нефти и газа в Баренцевом море [89]. Актуальным является создание национального стандарта Российской Федерации, первая редакция которого подготовлена ООО «Газпром ВНИИГАЗ», - РФ ГОСТ Р «Нефтяная и газовая промышленность. Арктические операции. Технические средства противопожарной защиты морских платформ. Общие требования» [90]. Национальный стандарт планируется применять при разработке проектной документации предназначенных для эксплуатации в северных условиях морских платформ.

При реализации арктических проектов основное внимание операторы и органы управления программами развития уделяют экономической эффективности, оставляя на втором плане решение экологических проблем. Так, сложившееся в разных странах законодательное регулирование в сфере нефтегазового комплекса стимулирует компании, которые самостоятельно следят за выполнением норм уровня загрязнения окружающей среды и безопасности. При этом главным стимулирующим фактором для компаний является экономическая эффективность. Компании вкладывают необходимые средства в обеспечение безопасности, так как в случае аварийных ситуаций финансовые затраты могут в разы превышать объем денежных средств, направляемых на безопасность проведения работ. При этом специалисты отмечают низкую технологическую готовность к безопасному освоению месторождений и ликвидации последствий аварий на арктическом шельфе.

Следует отметить положительные тенденции при разработке корпоративных локальных систем обеспечения экологической безопасности. В качестве примера можно привести компанию ПАО «НК “Роснефть”». В рамках охраны арктической окружающей среды разработана Декларация об охране окружающей среды и сохранении биологического разнообразия при разведке и разработке минеральных ресурсов Арктического континентального шельфа Российской Федерации (совместно с компаниями-партнерами: Statoil, Eni, ExxonMobil). Планируется создание комитета 
по вопросам охраны труда, техники безопасности и охраны окружающей среды при реализации геолого-разведочных работ на лицензионных участках в Карском море (совместно с ExxonMobil), а также создание Российского центра освоения Арктики на острове Белый (по инициативе властей Ямало-Ненецкого автономного округа). При непосредственном участии ПАО «НК “Роснефть”» разработаны стратегическая программа действий по охране окружающей среды Арктической зоны Российской Федерации, проект федеральной целевой программы «Ликвидация последствий загрязнения и иного негативного воздействия на окружающую среду в результате экономической деятельности на 2014-2025 гг.» и другие документы. Несмотря на имеющиеся экологические проблемы, формируется система, обеспечивающая безопасность для повышения устойчивости развития регионов Севера и Арктики.

Проекты комплексного освоения месторождений арктического шельфа на больших глубинах, в частности в Чукотском и Восточно-Сибирском морях, не рентабельны и могут использоваться, в основном, в научных целях. Необходимо отдельно отметить решение правительства Российской Федерации о временном моратории на выдачу лицензий на участки континентального шельфа России. По оценкам Федерального агентства по недропользованию, планировать отмену этого моратория возможно только при цене на нефть в 100 105 долл. США за баррель. Скорости бурения на шельфе Арктики остаются низкими, поэтому все компании, обладающие лицензиями на освоение участков арктического шельфа, рискуют не выполнить принятые на себя обязательства, согласно которым до 2020 г. в среднем в год необходимо было пробурить двенадцать скважин. По состоянию парка буровых установок на конец 2019 г. выполнение такого объема бурения было просто физически невозможно. Фактически за период 2011-2019 гг. в Карско-Баренцевоморской провинции пройдены всего три разведочные скважины (одна в 2011 г., две в 2014 г.) [91, 92].

Освоение нефтегазовых месторождений существенно зависит от возможности приобретения импортного оборудования и инновационных технологий. Доля импортного оборудования для освоения трудноизвлекаемых ресурсов составляет порядка $50 \%$, для эксплуатации традиционных месторождений - менее $20 \%$, для производства сжиженного природного газа - $80 \%$, для обустройства промыслов на шельфе - более $80 \%$, для управления добычей на особо сложных месторождениях - до 90 \% [93].

Корпорация ПАО «Газпром нефть» сформулировала более пятидесяти направлений исследований и создания технологий, способных конкурировать с импортными аналогами [94]. В качестве примера можно привести проект, который разрабатывается в Свердловской области, для производства бурового оборудования в арктическом исполнении. Это блочно-модульная установка, которая позволяет выполнять бурение в условиях низких температур при высокой скорости ветра. Заказчик оборудования - ООО «Интегра-Бурение», которое планирует использовать инновационный комплект в Ямало-Ненецком автономном округе для освоения Южно-Тамбейского месторождения [95].

Российской венчурной компанией предлагается создание инвестиционного товарищества "North Energy Fund I Seed", которое ориентировано на инвестирование в энергоэффективные проекты на ранней стадии, а также в разработку технологий нового поколения в нефтегазовой сфере. Фонд планирует инвестировать в технологии радиального бурения, позволяющие существенно увеличить извлечение нефти из низкодебитных скважин. Так, благодаря инвестированию в ООО 
«Перфобур» (г. Уфа) разработана буровая установка с гибкой компоновкой нижней бурильной колонны для проведения сервиса по перфорации и стимуляции старых и маргинальных скважин [96, 97].

Компания ООО «Сейсмо-Шельф» разработала инновационную технологию поиска и разведки углеводородного сырья на арктическом шельфе России, основанную «на использовании многокомпонентных автономных донных регистраторов для сейсмических исследований на глубинах до 500 метров». Эта технология использована ПАО «НК “Роснефть”» на лицензионном участке «Северо-Карский» для проведения геолого-разведочных работ, а также контроля качества сейсморазведочных работ 2Д [98].

Успешность уже начатых развивающих проектов и перспектива расширения инвестиционной программы, нацеленной на достижение стратегических целей национальной политики развития арктических территорий, определяются прогрессом в изыскании адекватных ответов на шесть «больших вызовов», критических для наращивания масштабов индустриализации Арктики.

1. Технологический вызов, который определяется отсутствием прогрессивных структурно-технологических сдвигов для продвижения к пятому и шестому технологическим укладам в северных регионах [99].

2. Правовой вызов, который характеризуется недостаточным законодательным обеспечением в сфере инновационной и научной деятельности, в первую очередь отсутствием федеральных законов «Об Арктической зоне Российской Федерации» и «Об инновациях и инновационной деятельности».

3. Кадровый вызов, который характеризуется дефицитом квалифицированных кадров в регионах Севера и Арктики. Этот вызов тормозит практическое использование новых научных знаний и реализацию прорывных технологий для промышленной, научно-технической и инновационных сфер. Решить проблему дефицита кадров только за счет переезда специалистов из других регионов не реально. Решение возможно в направлении открытия образовательных учреждений в малых городах регионов, имеющих необходимый профессорско-преподавательский состав (примером такого потенциального образовательного центра может служить г. Апатиты в Мурманской области, где функционирует самый крупный в Арктике Федеральный исследовательский центр «Кольский научный центр РАН»).

4. Информационный вызов, который заключается в недостаточном обеспечении информацией о последних научных достижениях. Это препятствует развитию трансфера технологий и интенсивности процессов технологического обмена. Промышленные предприятия замкнуты на собственном потенциале, в связи с чем не проявляют активность в поиске новых источников информации для разработки и реализации инновационных проектов.

5. Интеграционный вызов, который характеризуется недостаточным количеством и масштабом корпоративных структур, соответствующих крупнейшим мировым компаниям, обладающим способностью создавать и осваивать инновационные технологии и укреплять стратегические связи с квалифицированными поставщиками и клиентами на международном и внутрироссийском рынках.

6. Транспортный вызов, который характеризуется недостаточным развитием единой транспортной системы. 


\section{2. Обеспечение промышленной безопасности в Арктике: новые «большие вызовы» и перспектива их преодоления с использованием инновационных технологий и проектного управления природно-технической мегасистемой}

По темпам урбанизации и хозяйственного освоения арктических территорий Советский Союз в XX в. многократно превосходил все циркумполярные страны. Лидерство в строительстве инфраструктуры городов и промышленных сооружений в зоне вечной мерзлоты в значительной мере предопределялось успехами Академии наук СССР в развитии научных основ геомеханики мерзлых грунтов. Трудами членакорреспондента АН СССР Н. А. Цытовича и его академической школы в 1934-1937 гг. были обоснованы физико-химические и геомеханические модели структуры и поведения грунтов типа МВЛГ, состоящих из четырех фаз — «минеральный каркас - вода - лед — газ» [100]. Эта базовая модель вошла во все учебники по геомеханике грунтов и в строительные нормы и правила, регулирующие порядок инженерно-геологических изысканий, проектирование и возведение крупных сооружений на вечной мерзлоте [101]. Модель Н. А. Цытовича успешно применяется до сих пор при расчетах устойчивости грунтовых оснований тех природнотехнических комплексов, у которых глубина локализации оснований не выходит за пределы верхней границы зоны стабильности газогидратов метана (ЗСГ). Это большая часть городской застройки и наземные сооружения промышленного назначения с относительно большими площадями опоры.

При освоении арктического шельфа на пороге третьего тысячелетия произошло скачкообразное изменение размеров морских платформ гравитационного типа, создаваемых для размещения на них оффшорных промыслов для добычи нефти и газа. Инициатором новой тенденции стала Норвегия, построившая в Северной Атлантике самые большие в мире платформы Troll-A и Statfjord-B, масса которых достигает 1,2 млн т, а площадь опорного основания составляет всего 16-20 тыс. м² [102]. При постановке платформ на морское дно дополнительная пригрузка грунтового основания в 300-700 кПа распространяется до глубины 50-150 м под фундаментом платформы. Поскольку платформы установлены в относительно теплых водах незамерзающей акватории Атлантики, пригрузка не вызывает аномальной реструктуризации грунтов в аномальной стрессовой области под гравитационной платформой.

Иная геомеханическая ситуация складывается в месте установки в 2011 г. в Печорском море первой российской мегаплатформы этого класса - МЛСП «Приразломная» - общей массой 650 тыс. т [103]. МЛСП эксплуатируется ПАО «Газпром нефть» более семи лет, обеспечивая добычу до 1,7 млн т нефти в год (при проектной мощности 7 млн т) [104].

При проведении инженерно-технических изысканий в месте установки платформы грунты, насыщенные газогидратами, выявлены не были. Однако, после постановки сверхтяжелой гравитационной платформы на сложенное субаквальной мерзлотой дно на глубине моря 17 м с отрицательной температурой придонного слоя воды, следовало бы ожидать относительно быстрое формирование линзы насыщенных газогидратами грунтов типа ГСГГ в области дополнительной пригрузки под фундаментом на глубинных уровнях разреза до 200-400 м (рис. 5). Разрастание этой линзы в объеме может привести к смене «нормального» режима проседания, типичного для добычных промыслов с высоким дебитом, на режим воздымания с 
угрозой одномоментного обрушения вследствие деструкции газогидратов под воздействием техногенного стресса или мощных электромагнитных «штормов» геофизической среды [71].

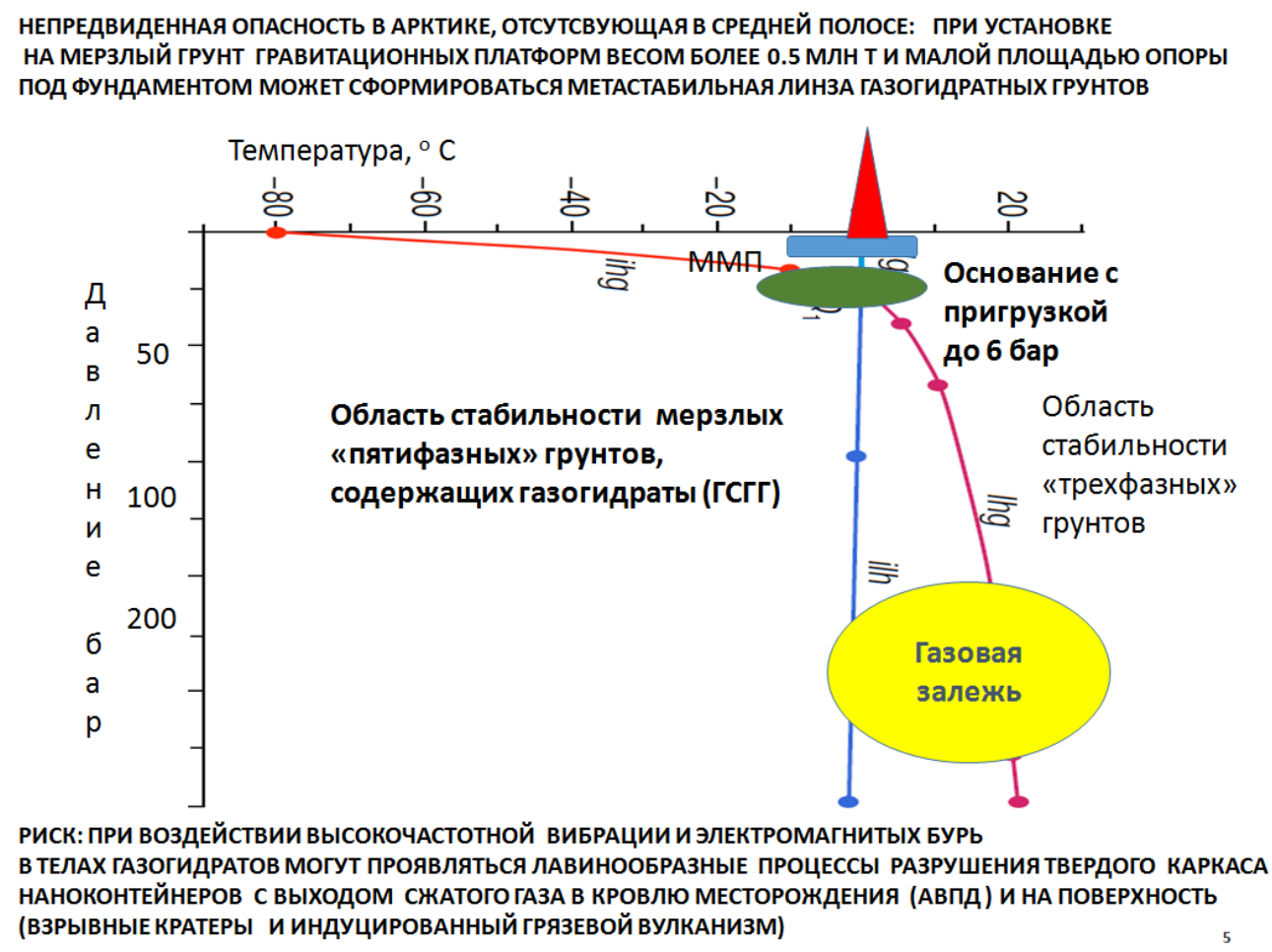

Рис. 5. Концептуальная схема формирования взрывоопасной линзы насыщенных газогидратами грунтов под основанием сверхтяжелых гравитационных платформ, устанавливаемых на мелководных участках арктического шельфа в пределах зоны стабильности газогидратов в субаквальной вечной мерзлоте (по [71])

По большому счету, это пионерный опыт создания на арктическом шельфе конкурентоспособного нефтедобывающего промысла, который можно рассматривать в качестве свидетельства готовности России к переходу на высший технологический уровень организации производства в оффшорном секторе экономики Арктики.

К сожалению, это технологическое достижение служит одновременно и примером неоправданно рискованной стратегии индустриализации арктической территории без адекватного учета специфических отличий ее природной среды от хорошо изученных параметров природно-технических комплексов (ПТК) в «старых» промышленных областях, действующих в теплых климатических зонах. Как правило, при организации работ в Арктике учитываются отличный от средних широт ритм смены дня и ночи, повышенная длительность холодовых сезонов и наличие движущегося ледового покрова в акватории Северного Ледовитого океана и арктических морей. Вне поля зрения проектантов ПТК до сих пор остаются «большие вызовы», связанные с особым режимом геофизических полей в Авроральном циркумполярном овале и со спецификой флюидодинамики в зоне стабильности 
газогидратов, находящихся в Арктике в близиповерхностных горизонтах криосферы. Недооценка рисков во многом обусловлена низким уровнем развития «инструментария» (технических средств и методов) для контроля фазовых переходов в сложных флюидных системах недр на границах ЗСГ, а также для мониторинга вариаций геомеханических параметров недр при быстрых изменениях состояния геофизических полей, обусловленных электромагнитными бурями и скачкообразными повышениями пластового давления при миграции флюидов в блоках подземного пространства, расположенных между добычными платформами и глубинными залежами углеводородного сырья. Неполнота знаний об этой группе опасных природных процессов ярко проявляется в том, что в современных учебниках и руководствах по проведению инженерно-геологических изысканий и строительству на мерзлых грунтах [105-109] не прописаны требования и процедуры по выявлению грунтов, насыщенных газогидратами (новый тип грунтов с условным кодом «ГСГГ», отсутствующий на строительных площадках умеренных климатических зон). Негативным последствием указанного недостатка требований к полноте изучения геологической структуры грунтовых оснований является игнорирование операторами ПТК потребности в укомплектовании добычных комплексов высокочувствительными техническими средствами для дистанционного контроля геомеханического режима недр и миграции флюидов в течение всего жизненного цикла отработки месторождений [110].

Сложившаяся практика освоения углеводородных полей на арктическом шельфе и побережье замкнута в «порочном круге»: девелоперы пионерной волны не озабочены формированием мониторинговых систем, обеспечивающих промышленную и экологическую безопасность создаваемых ПТК, поскольку в действующих СНиП соответствующие требования не упоминаются. Специалисты по предваряющим строительство изысканиям, в свою очередь, не ставят перед собой задачи выявления вызовов и риск-факторов, не перечисленных напрямую в техническом задании, поскольку инициативный поиск может послужить поводом для обвинения в нецелевом расходовании выделенных на изыскания средств. Государственные научно-исследовательские учреждения также не получают целевого бюджетного финансирования на изучение вызовов, не интересующих девелоперов арктических проектов. Ранее определенную свободу выбора поисковой тематики имели институты Российской академии наук, но после реформы 2013 г. финансовая поддержка работ академии, выходящих за горизонт прикладного спроса, редуцирована до минимума - порядка 4 млрд руб. в год, «размазанных» по сотне научных направлений, признанных Президиумом РАН «приоритетными» или «прорывными». В результате столь недальновидной политики научное обеспечение арктических проектов не опережает практические развивающие действия, как это было принято на первом этапе «покорения» Арктики в СССР, а отстает на десятилетия от хозяйственных инициатив новой генерации девелоперов-практиков.

Сложившийся в Арктике стиль развивающих действий без учета рисков, связанных с плохо изученными к настоящему времени «большими вызовами», таит в себе угрозу тяжелых непредвиденных аварий с катастрофическими последствиями для легко уязвимых арктических экоценозов. Предварительный беглый анализ аварийных инцидентов в нефтегазовом секторе мировой экономики показывает, что при переходе к использованию мегамасштабных ПТК экстраординарные отклонения от «нормального» режима функционирования сверхсложных производственных систем, не опирающихся на надежную базу знаний, могут спровоцировать 
экономические потери, многократно превышающие ожидающуюся выгоду. В сфере экологии потери от крупных аварий в Арктике вообще невосполнимы, особенно в аспекте сохранения биоразнообразия $[110,111]$.

В этой связи уместно обратить внимание разработчиков программ освоения минерально-сырьевых и энергетических ресурсов арктических территорий на существенное отличие свойств грунтовых оснований на промплощадках Арктики и областей умеренного климата. На территории, занимаемой в настоящее время арктическими морями, в недавнем прошлом (6-17 тыс. лет назад) было развито мощное покровное оледенение, островные реликты которого сохранились в Гренландии и на арктических архипелагах. Под толщей льдов в слое вечной мерзлоты ЗСГ занимала интервал глубин от 20 до 700 м, что способствовало формированию в осадочном чехле будущего шельфа и побережья Евразии грунтовых блоков типа ГСГГ и залежей газогидратов метана [112-114]. В современную эпоху межледниковья и климатического оптимума этот тип горных пород выведен из поля термодинамической устойчивости, однако при медленном и плавном режиме растепления и уменьшения статической нагрузки по мере таяния ледникового покрова газогидратные блоки над верхней кромкой ЗСГ могут оставаться неразрушенными, пребывая в метастабильном состоянии в течение тысячи лет благодаря эффекту самоконсервации (рис. 6) [70, 115].

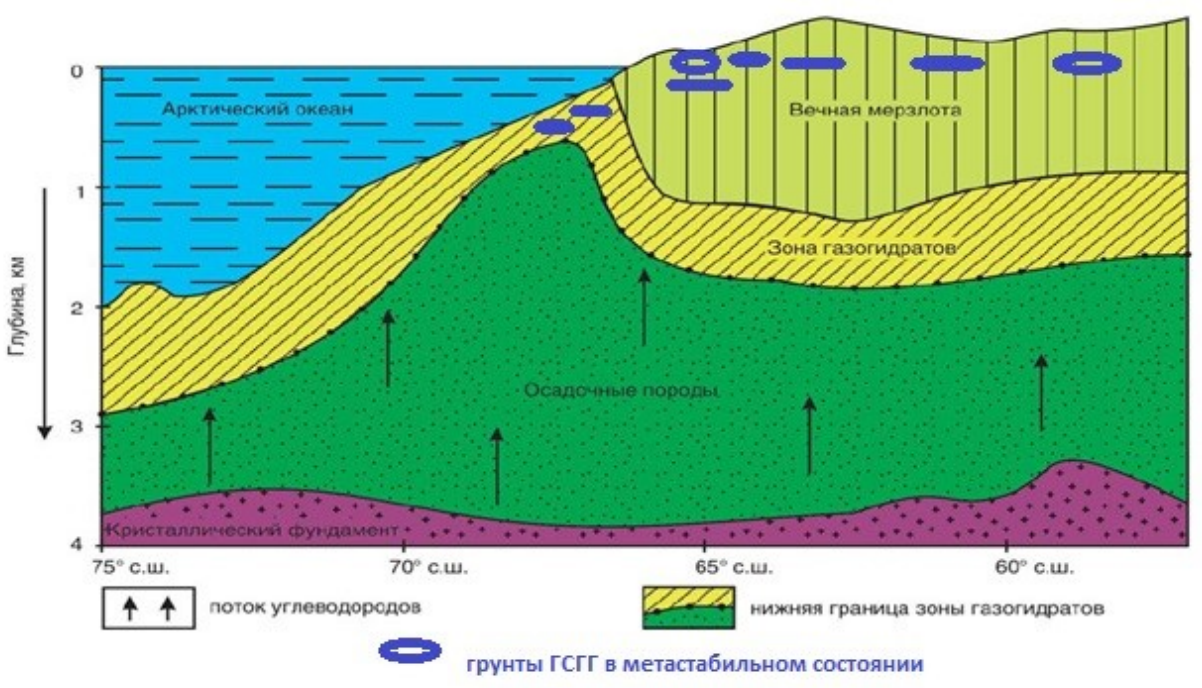

Рис. 6. Схема геологической позиции зоны стабильности газогидратов ЗСГ (косая и вертикальная штриховки) и линз мерзлых грунтов типа ГСГГ, насыщенных метастабильными газогидратами метана, в многолетнемерзлом осадочном покрове Арктики (по [31] с авторским дополнением, учитывающим материалы [70, 71, 112-115])

В приповерхностном слое вечной мерзлоты под «активным горизонтом» сезонного протаивания повсеместно распространены линзы ГСГГ, которые с позиций инженерно-строительной практики следовало бы относить к столь же опасным видам грунтов, как плывуны или зыбучие пески.

Уникальность геомеханических свойств ГСГГ, требующая выделения их из категории обычных четырехфазных грунтов типа МВЛГ, обусловлена присутствием наноструктурированных компонентов в виде клатратных соединений воды и 
углеводородов (метана с незначительной примесью более тяжелых полимеров этана, бутана и пропана). Водно-метановые клатраты можно представить в виде своего рода «сотовых наноконтейнеров», в которых сферические емкости со стенками из кристаллического льда заполнены сжатым газом [116]. Аналитический обзор существующих литературных данных о петрофизических свойствах клатратных компонентов мерзлых грунтов выявил отрывочность и статистическую непредставительность экспериментальных результатов, явно недостаточных для построения надежных количественных моделей, необходимых для инженерных расчетов грунтовых оснований сооружений повышенной категории ответственности.

Известно, что степень сжатия газа в клатратных наноконтейнерах в 120-160 раз выше, чем в пузырьках свободного газа, находящихся в неструктурированных порах и трещинах минеральной матрицы грунтов [116]. Установлено также, что плотность газогидратной компоненты ГСГГ на 10-12 \% меньше плотности чистого льда, а теплопроводность в сотни раз ниже, чем у тонкодисперсных разновидностей грунтов типа МВЛГ [117]. При нагружении ГСГГ консолидируются быстрее, чем грунты типа МВЛГ, в компактированном состоянии их пластичность ниже, чем у литифицированных глин и илов $[118,119]$. С позиций проектных расчетов чрезвычайно важной особенностью ГСГГ является резкое снижение прочностных параметров при разрушении клатратного каркаса и эмиграции высвобожденного метана в окружающую среду. При высокой газопроницаемости покрышки над линзами ГСГГ происходит образование «газоходов» (chimney в англоязычных публикациях), разгружающих восходящие потоки метана через грифоны на дне моря или взрывные воронки на суше [120-124].

Специфической чертой ГСГГ является нелинейная реакция на внешние физические воздействия [125-129], что в предельных случаях приводит к проявлению импульсных взрывных процессов и грязевому вулканизму в приповерхностных уровнях территорий, содержащих в своих недрах линзы ГСГГ и залежи газогидратов в метастабильном состоянии. В случае низкой газопроницаемости вмещающих породных толщ (в особенности перекрывающих горизонтов) при фазовом переходе твердых клатратных соединений в водно-газовый флюид в недрах будут возникать участки аномально высокого пластового давления (АВПД) и «газовые карманы», в которых внутреннее давление значительно превышает статическую нагрузку. Вблизи поверхности и в активном слое вечной мерзлоты восходящие потоки метана вызывают рост газогидратных пинго - куполообразных поднятий высотой до 30 м и поперечником от десятков до сотен метров. Этот тип потенциально опасных геоморфологических структур выделен лишь в последнее десятилетие по результатам исследования полей гигантских кратеров и пинго на шельфе Баренцева моря и взрывных воронок на Ямале (рис. 7, 8) [70, 110, 111, 123, 128, 129].

Предложение ученых Российской академии наук, неоднократно высказанное на многочисленных арктических форумах и конференциях последних лет, отнести это неизвестное ранее явление к категории «больших вызовов», противодействие которым следует в обязательном порядке предусматривать во всех проектах природопользования на арктических территориях, пока не дало ощутимых практических результатов. Среди действующих акторов освоения Арктики все еще пользуется почти всеобщим признанием традиционная концепция классической школы мерзлотоведов, объясняющая происхождение всех типов морфоструктур на поверхности слоя вечной мерзлоты реакцией на климатические изменения. Столетняя история маломасштабной индустриализации арктического побережья Евразии и 
Северной Америки как будто подтверждает правомерность подобного стратегического выбора научного обоснования сложившегося стиля обустройства инфраструктуры промышленных районов, но в отношении экологической безопасности мегаразмерных ПТК, формирование которых началось на пороге третьего тысячелетия, такой «успокоительный» подход нельзя признать приемлемым и адекватным. Требуется усложнение модели природопользования с введением в нее факторов, учитывающих возрастающее взаимодействие техносферы с глубинными слоями недр и ионосферой.
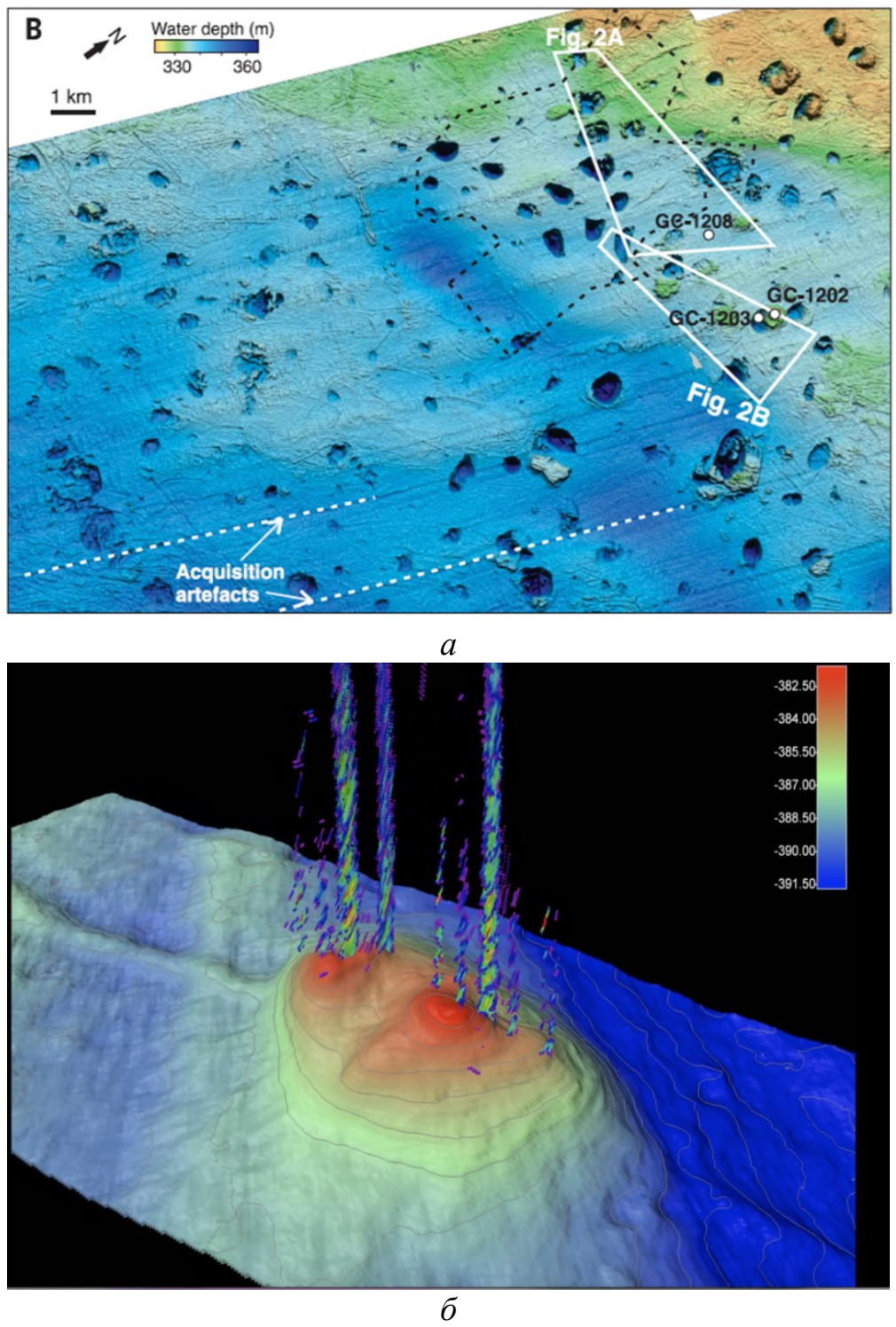

Рис. 7. Поле гигантских кратеров (a), образовавшихся на месте взорвавшихся куполов газогидратных пинго (б) в Западно-Баренцевоморской нефтегазовой провинции (по материалам Норвежского центра исследования арктических газогидратов $[72,123])$ 


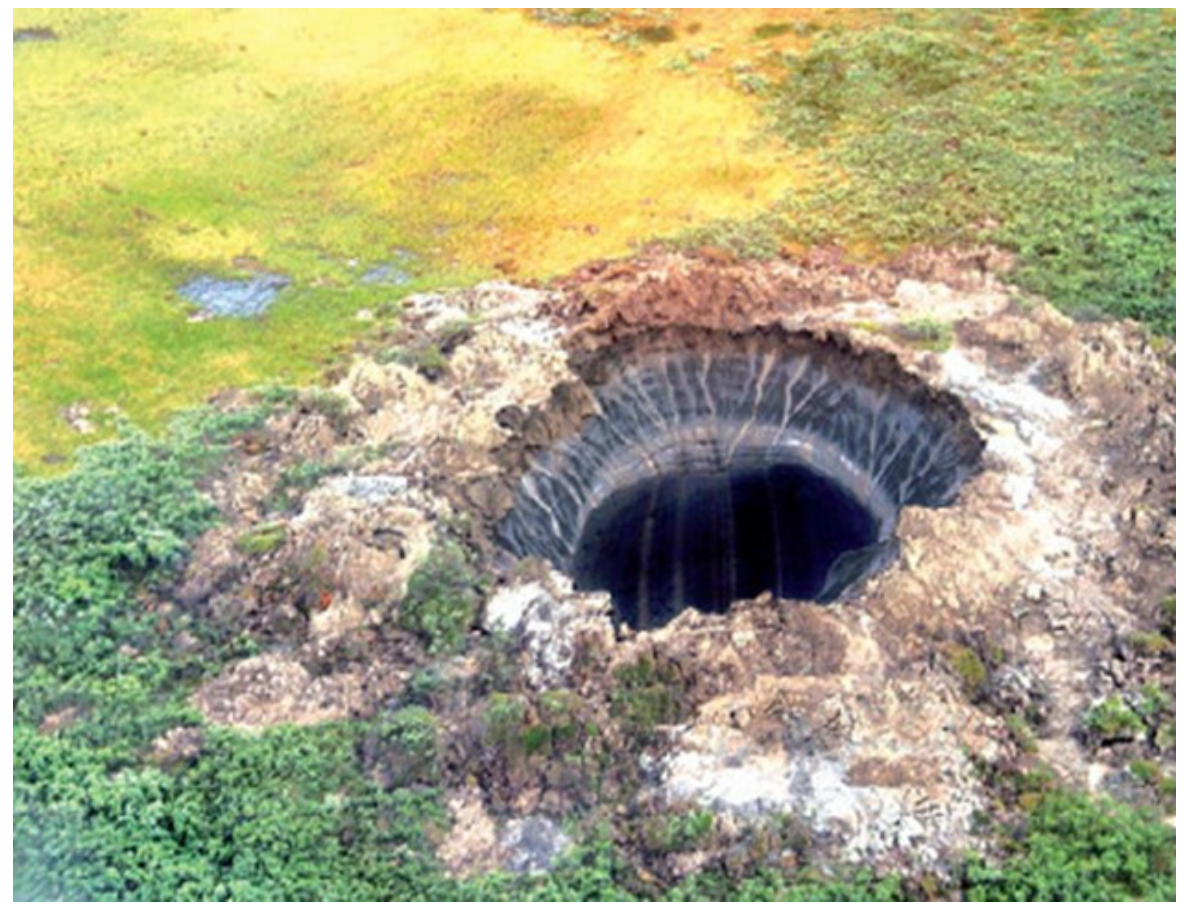

a

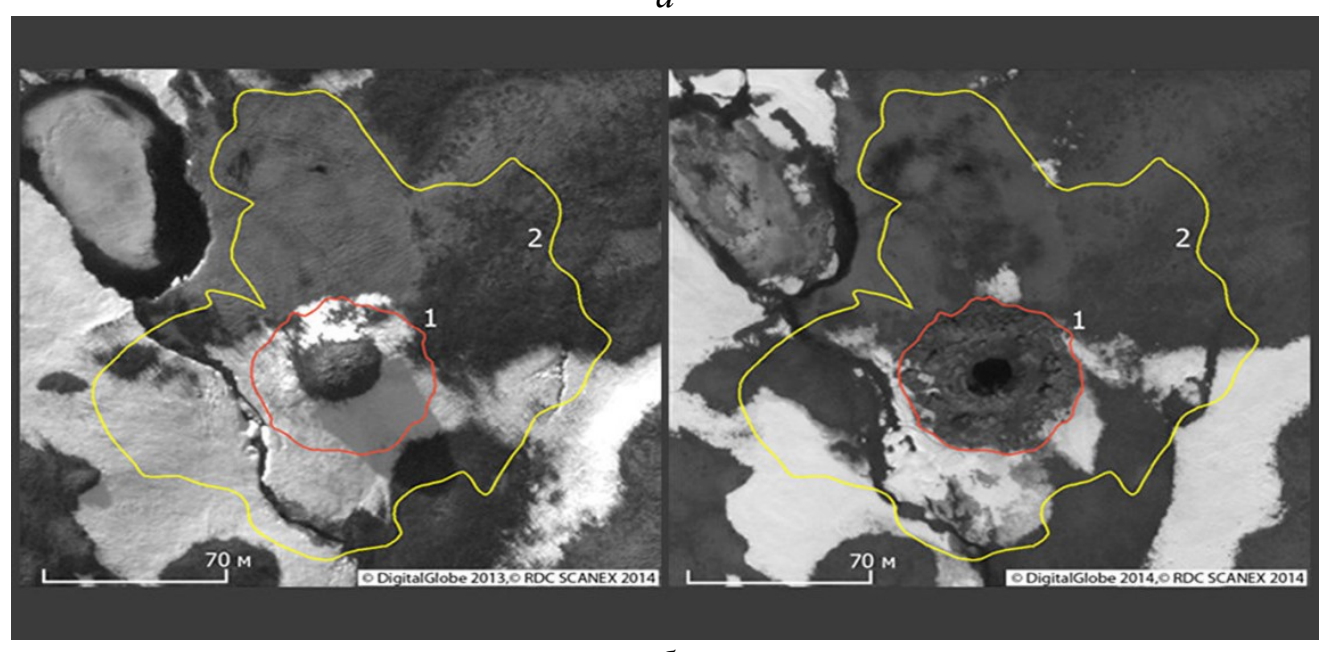

$\sigma$

Рис. 8. Гигантская Ямальская воронка № 1 в слое вечной мерзлоты $(a)$, обнаруженная в 2013 г. в пределах Бованенковской газоносной структуры [70, 71, 110, 111]); диаметр 60 м, глубина 40 м, окружена валом глыб ледогрунта, выброшенного взрывом на расстояние 70-120 м от края (фото члена-корреспондента РАН В. И. Богоявленского в период вертолетного облета площади в июне 2013 г.). Реконструкция жизненного цикла Ямальской воронки № 1, выполненная В. И. Богоявленским [111] по космоснимкам высокого разрешения (б): слева — растущий булгуннях (2011 г.); справа — округлое озеро на месте взорвавшегося булгунняха (2018 г.); юная фаза взрывного кратера (через год после образования) показана на рисунке $a$ 
В свете результатов научных исследований криосферы, полученных в XXI в., представляется необходимым резкое увеличение вложения средств в проблемно-ориентированные программы работ по ускоренному заполнению очевидных пробелов в базах знаний о геомеханических свойствах мерзлых пород, содержащих наноструктурированные агломераты газогидратов с нелинейным характером отклика на внешнее воздействие. Особое внимание следует уделить изучению механизма взрывного разрушения газогидратов метана при воздействии на них высокочастотной механической вибрации и резких вариаций электромагнитных волновых полей. Согласно теоретическим расчетам [130], в заполненных газом наноячейках при вибрации может происходить самопроизвольный разогрев газов до сверхвысоких температур. Из этого следует, что при проходке скважин в толще ГСГГ возможно мГновенное разрушение ледового каркаса клатратных агломератов с импрегнацией разогретого газа во вмещающую породную матрицу, что может спровоцировать локальное проявление АВПД в импактной зоне, механическое повреждение ствола и бурового оборудования, пожар в скважине.

В авроральном поясе Арктики мощные электромагнитные бури могут вызвать еще более масштабную деструкцию малоглубинных газогидратных блоков. Экспериментально установлено, что потоки электромагнитного излучения с мегагерцовой частотой способны разрушать газогидратные кластеры $[131,132]$. В период мощных «штормов» в приполярном секторе ионосферы генерируются энергопотоки мощностью до 1,4 ГВТ и земной поверхности достигает излучение с частотным диапазоном 1-6 МГц [133]. Влияние этих токов на линейные структуры техносферы (линии электропередач, трубопроводы и т. п.) давно изучается и контролируется во всех приарктических странах, тогда как публикаций по оценке масштабов деструкции газогидратов вследствие вариаций электромагнитного поля практически нет. Учитывая то обстоятельство, что в национальной стратегии освоения Арктики предусмотрено активное строительство крупных нефтегазовых промыслов в осевой части аврорального пояса, было бы целесообразно включить в число приоритетных научных задач изучение влияния ионосферных процессов на промышленную безопасность создаваемых здесь ПТК гражданского и оборонного назначения.

Уместно напомнить, что Россия первой в мире выявила и освоила в промышленном масштабе добычу газа из твердотельной газогидратной «шапки» Мессояхского месторождения газа в Красноярском крае, однако до настоящего времени в сфере промышленной безопасности роль газогидратов остается недооцененной [134]. Влияние газогидратных компонентов не принято учитывать даже при обосновании проектов размещения в толщах вечной мерзлоты таких инженерных объектов высшей категории опасности, как подземные атомные станции и хранилища радиоактивных отходов $[135,136]$. Лишь в работах отраслевого института ВНИИГАЗ удалось найти перспективные предложения по применению специальной технологии, повышающей безопасность строительства эксплуатационных скважин в толщах многолетнемерзлых пород с горизонтами ГСГГ [137].

Вероятной причиной «игнорирования» газогидратов экспертами по промышленной и экологической безопасности является отсутствие в России эффективных технических средств для их выявления и прослеживания в процессе геологического картирования территорий и проведения разведочных 
работ. Даже на эксплуатировавшемся более двадцати лет Мессояхском месторождении не было добыто и изучено ни одного образца газогидрата [138]. Присутствие газогидратов в недрах разведываемых нефтегазовых полей обосновывается лишь по косвенным данным геофизического каротажа буровых скважин [139] либо на основе расчетных балансовых моделей эксплуатируемых залежей [138]. Разрешающая способность применяемых в России методик на порядок ниже, чем у разработанных еще в 2008 г. норвежских программноаппаратных комплексов сейсморазведки на основе волоконно-оптических измерительных средств [139-142].

Передовые позиции в регламентации правил инженерно-геологических изысканий занимает Канада, которая еще в 2012 г. предложила в обязательном порядке оценивать масштабы распространения газогидратных блоков при оценке рисков освоения нефтегазовых полей на арктических территориях [143]. В США в процессе разведки нефтеносных полей Аляски в начале 2000-х гг. было выполнено районирование территории по распространенности газогидратных залежей, рассматриваемых не в качестве дополнительного источника углеводородов, а как фактор, осложняющий организацию добычи нефти. В 2017 г., после появления информации о возможностях взрывной дегазации недр при разрушении залежей газогидратов под воздействием техногенного стресса, экологические требования к промышленной безопасности продуктивных ПТК в США были ужесточены настолько, что большинство операторов арктических проектов предпочло приостановить разведку и обустройство промыслов на неопределенный срок - до развития технологий, гарантирующих надежный контроль и управление рисками.

Норвегия в 2013 г. создала специализированный Центр изучения газогидратов и их влияния на климат и экологическую обстановку в морях Арктики [72] и инвестировала огромные средства в создание высокочувствительных донных систем сейсмоакустического мониторинга флюидодинамики недр. На крупнейших оффшорных промысловых площадках в Северном море установлены конверсионные кабельные сети типа фазовых антенн FOSAR и OPTOSEIS с числом регистрирующих ячеек от 2400 до 10000 $[71,142]$. Для адекватного контроля и управления геодинамическим режимом нефтегазовых полей в зонах материковой и субаквальной вечной мерзлоты необходимо включение в состав промысловых комплексов мониторинговых сейсмоакустических сетей типа донных фазовых решеток на базе ВОИС (рис. 9).

Государственная политика в сфере природопользования базируется на приоритете экологии над экономической выгодой, поэтому при разведке нефтегазовых полей требуется составление детальных 3D-моделей лицензионных блоков недр не только с оценкой запасов целевого продукта (нефти или газа), но и с надежной реконструкцией распространения в недрах газогидратных слоев как факторов риска. На стадии эксплуатации обязателен контроль поведения газогидратов и ассоциированных с ними флюидных производных в режиме 4D, что повышает безопасность оффшорных промыслов и одновременно позволяет управлять миграцией флюидных фаз в недрах, повышая коэффициент извлечения нефти до рекордных 68 \% (для сравнения: на российских промыслах этот показатель «в норме» принимается равным $26 \%$ ) $[63,71,144,146]$. В полном соответствии с этой политикой развернута программа опережающей научно-технологической подготовки к освоению месторождений нефти в бывшей спорной зоне на границе морских 
владений Норвегии и России в западной части Баренцева моря. На отошедших в 2010 г. к Норвегии площадях шельфа планируется установить уникальную оптоволоконную кабельную сеть, содержащую до одного миллиона регистрирующих ячеек для геофизического контроля флюидодинамики недр [63, 71].

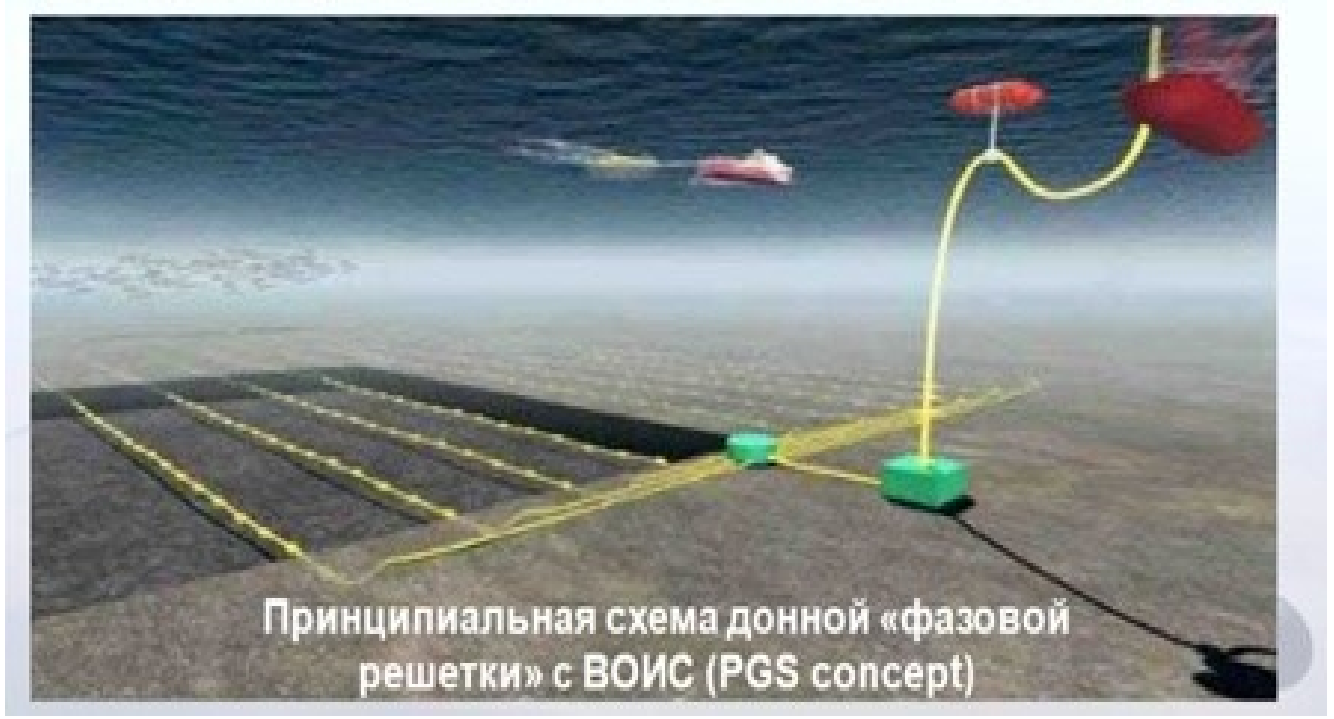

Рис. 9. Концептуальная схема применения донных сейсмоакустических фазовых антенн для контроля флюидодинамического режима на «умных» морских промыслах для добычи газа и нефти (по материалам обобщения норвежского опыта в [71, 142, 144, 145])

Экспертный совет по Арктике и Антарктике Совета Федерации неоднократно обращал внимание руководителей национальной программы освоения Арктики на отставание России в вопросах технологической поддержки оффшорного сектора экономики Арктики, в первую очередь в части снижения рисков промышленной деятельности и повышения конкурентоспособности арктических ПТК. Так, в 2010 г. было рекомендовано «...закрепить законодательно обязательное включение в лицензионные соглашения на право разведки и освоения уникальных и крупных нефтегазовых месторождений в АЗРФ требования о применении сейсмомониторинговых технологий 4D-4C для надежного контроля и управления деформационными процессами в недрах и профилактики техногенных землетрясений с катастрофическими последствиями» [146]. Эта рекомендация не была реализована из-за отсутствия отечественной приборной базы, поэтому в 2012 г. Экспертный совет повторно рекомендовал возобновить в России производство геофизической аппаратуры, необходимой для формирования мониторинговых систем на лицензионных площадях Арктики. Практических шагов по воплощению в жизнь решений Экспертного совета до 2019 г. не было сделано, хотя актуальность их значительно возросла после введения в 2015 г. жестких санкционных ограничений на поставки техники и сервисных услуг российскому нефтегазовому сектору.

Действующая в настоящее время в Арктике государственная система геофизического мониторинга не обеспечивает контроль локальной сейсмичности в пределах нефтегазовых провинций, поскольку опорные наземные сейсмостанции расположены на тысячекилометровых расстояниях 
друг от друга, что не дает возможности регистрировать низкоэнергетические события, индуцированные деятельностью ПТК [63, 144]. Для принципиального улучшения ситуации в Российской академии наук была разработана концепция формирования в Арктике современной гибридной системы геофизического мониторинга. С учетом передового опыта морских держав с высоким технологическим потенциалом предлагается строить перспективную систему на основе кластерных сейсмоакустических модулей, локализованных на морском дне, на побережье Северного Ледовитого океана и островных архипелагах, при этом в максимально возможной степени интегрировать контроль геофизических процессов с гидрометеорологическими наблюдениями и дистанционным зондированием Земли с применением космических аппаратов [63, 71, 145, 147, 148].

Из имеющегося научного задела и планов промышленного развития Арктики представляется целесообразным выбрать в качестве тестового полигона для пилотного комплекса будущей общеарктической системы мониторинга центральную часть Карско-Баренцевоморской нефтегазовой провинции, где уже созданы крупномасштабные ПТК, не оснащенные должным образом локальными системами мониторинга и контроля опасных флюидодинамических процессов. На втором этапе опытным полигоном может стать шельф Карского моря между Новой Землей и Ямалом. Здесь сосредоточены наиболее крупные месторождения углеводородов (Победа, Ленинградское, Русановское), еще не вовлеченные в эксплуатацию и потому сохраняющие в исходном состоянии грунтовые и геомеханические условия, не подвергшиеся техногенному стрессу и модификации.

Формирование сети геофизического мониторинга в Арктике отвечает национальным геополитическим интересам и способствует повышению конкурентоспособности корпораций, действующих в регионе в качестве головных операторов индустриальных проектов. Следовательно, финансирование мероприятий по формированию сети можно строить на принципах государственно-частного партнерства, однако для успешной реализации такого подхода потребуется изменение механизма управления всей национальной программой развития Севера и Арктики. В настоящее время на волне эйфории от воплощения в жизнь прорывных мегапроектов в обустройстве технической инфраструктуры - МЛСП «Приразломная», порт и завод по сжижению природного газа в поселке Сабетта на Ямале, создание флота гигантских газовозов ледового класса серии «Ямалмакс» - внимание бизнессообщества сосредоточилось на изыскании инноваций, способных ускорить темпы индустриализации Арктики $[149,150]$. На второй план отошли вопросы гарантированного обеспечения экологической безопасности техносферы нового поколения и соблюдения требований экологического императива, декларированные в национальной Стратегии развития Арктики [151]. Дробление единой государственной программы на десятки не скоординированных между собой проектов, осуществляемых частными независимыми операторами, таит в себе угрозу нарушения стабильности среды обитания, поскольку большинство частных акторов не берут на себя в полной мере ответственность за поддержание разумного баланса между техносферной инфраструктурой и экосферой за пределами эксплуатируемых ПТК (а нередко и в их пределах).

Назрела необходимость в создании надведомственного органа управления Арктикой как единой природно-технической мегасистемой, в 
которой программно-целевое планирование в секторах жизнеобеспечения, экологической безопасности и национальной обороны будет гармонично сочетаться с контролируемой (т. е. не нарушающей экологический императив) эксплуатацией природных ресурсов на рыночных принципах $[152,153]$. Научное обеспечение управления должно опираться на базы знаний, генерируемые междисциплинарными научно-исследовательскими и экспертными центрами, ответственными за развитие нового научного направления - арктиковедения [154]. Прототипом центра такого рода может служить Федеральный исследовательский центр «Кольский научный центр Российской академии наук» (ФИЦ КНЦ РАН), имеющий 90-летний опыт развития «ноосферной» модели природопользования в Арктике [155]. 


\section{3. СТРАТЕГИЯ ИМПОРТОЗАМЕЩЕНИЯ ПРИ ОСВОЕНИИ УГЛЕВОДОРОДНОГО СЫРЬЯ}

\section{1. Актуальность импортозамещения при добыче углеводородов на арктическом шельфе}

Инновационные проекты на территории Арктики приобретают особое значение для страны. Это не просто проекты по освоению углеводородных месторождений на континентальном шельфе, а прежде всего проекты, направленные на обеспечение национальной безопасности, развитие транспортной, энергетической и социальной инфраструктур, минеральносырьевого комплекса Арктики, а также на повышение качества жизни населения коренных малочисленных народов Севера и населения страны в целом.

Арктические нефтяные и газовые проекты имеют большую важность для всей мировой экономики. По оценкам специалистов, к 2050 г. арктический шельф будет обеспечивать от 20 до 30 \% всей российской нефтедобычи [156]. В то же время у нефтегазового комплекса Арктики имеется ряд существенных проблем [157].

К сожалению, приходится констатировать сильную зависимость нефтегазового комплекса России от поставок импортного оборудования и технологий. Введение экономических санкций с запретом на поставки в Россию зарубежных технологий по освоению месторождений на арктическом шельфе, глубоководной добыче, увеличению коэффициента извлечения нефти, разработке трудноизвлекамых запасов углеводородов и оборудования для высокотехнологичного нефтегазового сервиса в долгосрочном периоде должны оказать негативное влияние на отрасль.

Необходимо значительное сокращение доли зарубежных компанийпоставщиков за счет энергичного и инициативного импортозамещения. Задача правительства состоит в том, чтобы не просто создать отечественное оборудование для работы на шельфе, а выстроить полноценный нефтегазовый сервис на отечественной технологической и кадровой базе.

Содействовать импортозамещению, а также привлечению иностранных инвестиций в отечественную нефтегазовую отрасль должна локализация разработки технологий и производства соответствующего оборудования для шельфовой нефтегазодобычи в Арктике в отечественных центрах компетенции и инноваций, опирающихся на высокоразвитый научный потенциал. По планам правительства РФ, доля импортного оборудования на внутреннем рынке для освоения арктических месторождений должна снизиться с 85 до 65 \% к 2020 г. и далее до $50 \%$ к 2025 г. [158].

С целью создания благоприятных условий для локализации производства инновационного оборудования и технологий были организованы ассоциация поставщиков нефтегазовой промышленности «Созвездие» (Архангельск) и ассоциация «Мурманшельф» (Мурманск), деятельность которых может служить основанием для развития потенциала реализации программы импортозамещения в арктической нефтегазовой отрасли. В дополнение к накопленному этими негосударственными организациями позитивному опыту научно-технической поддержки первых освоенческих проектов в Западной Арктике следует привлечь и лучшие практики взаимодействия гражданского сектора арктической индустрии с предприятиями оборонно-промышленного комплекса. Например, при подготовке к 
освоению Штокмановского газоконденсатного месторождения на шельфе Баренцева моря АО «ЦС “ЗВездочка”», откликаясь на потребности головного оператора проекта - АО «Росшельф», смогло освоить выпуск оборудования для подводных добычных комплексов, а также реализовало программу специальной подготовки отсутствовавших в стране кадров для осуществления сборки, испытаний, наладки и обслуживания подводных компонентов добычного комплекса.

К числу успешных примеров импортозамещения и локализации производств в Арктике можно отнести создание в 2011 г. Центра пропульсивных систем на базе подразделения специализированного винтообрабатывающего производства (СВОП) ОАО «ЦС “Звездочка”», научно-проектной организации «Винт» и опытного завода «Вега».

В этом же ряду позитивных практик стоит деятельность ЗАО «Белфрахт» (г. Архангельск), организовавшего производство герметичных контейнеров для бурового шлама, что позволило полностью отказаться от аренды аналогов у зарубежных нефтесервисных компаний.

В сфере производства труб различного диаметра и назначения отечественные компании также в состоянии стать конкурентами зарубежным производителям и значительно расширить свою долю как на внутреннем, так и на международном рынках. К примеру, ПАО «Челябинский трубопрокатный завод» и ПАО «Трубная металлургическая компания» являются надежными поставщиками насосно-компрессорных и обсадных труб для МЛСП «Приразломная», с которой отрабатывается одноименное месторождение нефти на шельфе Печорского моря $[159,160]$.

Следует отметить деятельность ПАО «НК “Роснефть”», организовывающего на Дальнем Востоке на базе судостроительного комплекса «Звезда» промышленный кластер. Кроме того, ПАО «НК “Роснефть”» расширяет судоремонтный комплекс в Мурманске. На следующем этапе запланировано строительство опорной базы берегового обеспечения шельфовых проектов в Арктической зоне Российской Федерации с созданием промышленного кластера нефтесервисных производств и центра сервисного обслуживания кораблей и судов, осуществляющих плавание в акватории Северного Ледовитого океана. По предварительной оценке, в первые десять лет производства объем импортозамещения по этому направлению составит порядка 6-7 млрд долл. США [161].

Основные усилия Министерства энергетики РФ в сфере импортозамещения направлены на нефтегазовое машиностроение и буровой сегмент нефтесервиса. Обеспечение геолого-разведочного сектора аппаратурно-техническими средствами возложено на Министерство промышленности и торговли (Минпромторг) и Министерство природных ресурсов и экологии (МПР) РФ, но из-за отсутствия эффективной координации действий уже многие годы наблюдается прогрессирующее отставание российских разработчиков от передового уровня, достигнутого в ведущих приарктических странах. В сфере осуществления буровых работ и геофизического исследования скважин и геологических разрезов перспективных нефтегазовых полей зависимость российских операторов от иностранных поставщиков технологий и технических средств близка к абсолютной. В условиях санкционного режима этот фактор предопределяет низкую степень изученности российского сегмента арктического шельфа - в десять раз ниже изученности американской части Чукотского моря и в двадцать раз ниже степени изученности шельфа Норвегии [162]. 
В целях постоянного обеспечения экономики запасами минерального сырья и геологической информацией о недрах государственной программой Российской Федерации «Воспроизводство и использование природных ресурсов» планируется рост геологической изученности страны, еe континентального шельфа и Арктики.

В 2016 г. в рамках государственной программы «Развитие судостроения и техники для освоения шельфовых месторождений на 2013-2030 годы» Минпромторгом России было выделено около 1,3 млрд руб. целевых средств и начаты работы по приоритетным проектам, отобранным совместно с ПАО «Газпром» $[163,164]$. Результативность этих работ до сих пор не получила официальной аудиторской или общественной оценки.

Санкционные запреты на поставку технологий и оборудования являются значительным препятствием для геофизических исследований. Сокращение объемов прибыли заказчиков, снижение возможностей кредитования, дефицит и рост цен на иностранное оборудование приводит к снижению объемов геофизических работ на новых лицензионных участках.

Количество отечественных поставщиков инновационных технологий для проведения геолого-разведочных работ весьма ограничено, сведения об их конкурентоспособности в борьбе с престижными западными сервисными компаниями отсутствуют. В качестве примера можно назвать ООО «СИ Технолоджи» и ООО «Пульс» из Геленджика, которые поставляют геологоразведочные технокомплексы и пневмоисточники для высокоразрешающей сейсморазведки; мурманское ООО «Моргеокомплекс», выпускающее опытные образцы донных сейсмостанций; ГНЦ РФ АО «Концерн ЦНИИ “Электроприбор”» (Санкт-Петербург), изготавливающий малые серии гравиметров, и ОАО «Енисейгеофизик», специализирующееся на выпуске невзрывных импульсных электромагнитных источников сейсмических колебаний [165].

В Мурманской и Архангельской областях, прилегающих непосредственно к наиболее изученной и перспективной части арктического шельфа России, сосредоточены наиболее крупные промышленные, транспортнологистические и научные центры, имеющие более чем столетний опыт работы в Арктике. Можно утверждать, что эти области имеют наилучшие предпосылки для формирования берегового опорного комплекса, обеспечивающего создание и эксплуатацию оффшорных морехозяйственных природно-технических систем в Западной Арктике, поскольку по причине высоких транспортных рисков и затрат на доставку грузов в Арктике производство и наладку оборудования для шельфовых техносферных объектов рационально локализовать как можно ближе к морским транспортным коммуникациям.

Вовлечение промышленных предприятий, геолого-разведочных и научно-исследовательских организаций регионов Арктики в производство товаров и услуг для нефтегазовой отрасли, а также локализация производства нефтегазового оборудования на прибрежных промплощадках незамерзающего Баренцева моря могут послужить стимулом к качественно новому витку в индустриализации, инфраструктурному и социально-экономическому развитию европейского сегмента северных территорий и к началу масштабного освоения месторождений углеводородного сырья на арктическом шельфе России. 


\section{2. Разработка и реализация стратегии импортозамещения}

Для Российской Федерации реализация проектов по добыче углеводородов на континентальном шельфе Арктики не только преследует коммерческие цели, но и является важнейшим системным фактором обеспечения экономического роста, национальной безопасности, совершенствования транспортной, энергетической и социальной инфраструктур, повышения качества жизни населения арктического макрорегиона.

В осуществлении своей национальной политики в Арктике Россия после 2014 г. вынуждена преодолевать негативные последствия многочисленных немотивированных «акций сдерживания» освоенческих мероприятий, предпринимаемых основными конкурентами, претендующими на передел ресурсного потенциала Арктики. Вопреки принципам свободной торговли по правилам ВТО ряд стран на основе претензий геополитического характера запретили поставки в Россию новейших технологий и оборудования, необходимого для организации экологически безопасного хозяйствования в Арктике. В частности, США запретили ввоз в Россию инновационного оборудования, не производящегося в России, в том числе райзеров, насосов высокого давления, буровых установок для горизонтального бурения, бурильных и обсадных труб, программного обеспечения для систем гидравлического разрыва пласта, устройств для сейсморазведки. Евросоюзом запрещена поставка технологий для шельфовых проектов, глубоководного бурения и разведки месторождений Арктики, специальных насосов [166].

Такие действия, безусловно, противоречат духу многочисленных международных соглашений по охране природной среды Земли в целом и Арктики в частности, а также двусторонним межгосударственным договорам о партнерстве в освоении арктический акваторий с гарантированным обеспечением на них экологической стабильности за счет применения наилучших известных практик. Отказывая России в поставках таких практик, западные страны повышают риск освоенческой деятельности, не принимая во внимание простую истину - техническая катастрофа в Арктике вследствие использования недостаточно безопасных технологий может вызвать глобальную климатическую или экологическую катастрофу.

С учетом этой лишенной логики и дальновидности линии поведения большей части участников современного витка в освоении Арктики, Россия вынуждена строить свою стратегию освоения развития северных регионов с опорой не на мировой опыт, а на доступные отечественные лучшие практики, призванные заменить импортные достижения западных разработчиков. Надо заметить, что до начала реформы экономической системы Россия обладала наибольшим опытом хозяйственных операций в арктических морях и строительства крупных природно-технических комплексов на арктическом побережье. В 1990-е и 2000-е гг. этот опыт был в значительной мере утрачен в ходе проведения политики депопуляции дискомфортных арктических земель. Усугубило ситуацию почти полное разрушение приборостроения в стране в ходе приватизации и перепрофилирования наукоемких высокотехнологичных производств, обеспечивавших нефтегазовый и геолого-разведочный секторы экономики. В режиме санкций Россия вынуждена вновь обратиться к стратегии 
импортозамещения недоступных западных технологий и средств отечественной продукции, как это уже было в 1920-е гг.

В настоящее время государственные органы управления Российской Федерации имеют достаточно широкий набор инструментов и мер для создания полноценной системы мотивации импортозамещения на критических направлениях технического прогресса, используя для этого не директивные механизмы принуждения, как это было ранее, а вполне рыночные защитные и стимулирующие подходы [167].

Меры и инструменты защитных механизмов направлены на защиту национальных производителей от иностранных конкурентов и связаны с созданием торговых барьеров для снижения конкурентоспособности иностранной продукции на внутреннем рынке. Их можно разделить на протекционистское и компенсирующее направления.

Целью мер протекционистского направления является ограничение ввоза зарубежной продукции и технологий или создание такой конъюнктуры, при которой импорт товаров в связи с повышением цены за счет выплат таможенных пошлин становится экономически не выгодным. Такая ситуация может быть вызвана квотированием и лицензированием импорта технологий и оборудования, повышением импортных пошлин, регулированием валютного курса, торговым эмбарго и санкциями, установлением национальных технических стандартов.

Меры компенсирующего направления являются обратной реакцией государства при применении протекционистской политики иностранного государства. Согласно Федеральному закону от 8 декабря 2003 г. № 165-Ф3 «О специальных защитных, антидемпинговых и компенсационных мерах при импорте товаров» такая реакция включает в себя введение антидемпинговых мер, компенсирующих пошлин, торговых квот и другие способы защиты своих производителей.

В условиях секторальных экономических санкций со стороны западных стран и запрета на ввоз в Российскую Федерацию технологий и оборудования для добычи углеводородов на арктическом шельфе, применение защитных механизмов импортозамещающей деятельности потеряло актуальность, которая вновь возникнет в случае снятия ограничений.

Стимулирующие механизмы применяются с целью повышения уровня конкурентоспособности отечественной продукции по отношению к иностранной посредством создания благоприятных условий для ведения бизнеса, введения особых налоговых и торговых режимов, субсидирования производства и др. Данная группа механизмов может быть разделена на два направления развивающее и поддерживающее.

Меры развивающего направления применяются для организации отечественного производства новой инновационной технологии и соответствующего оборудования. В этом плане для эффективной добычи углеводородов на арктическом шельфе необходимо строительство на отечественных предприятиях самоподъёмных и полупогружных буровых и добычных платформ, подводных добычных комплексов, оборудования и судов для проведения 3D-сейсморазведки. 
При разработке мер развивающего направления системы управления импортозамещающей деятельностью целесообразно использовать норвежский опыт освоения шельфовых месторождений.

Норвегия процесс освоения шельфовых месторождений северных морей начала с изучения технологий и привлечения иностранных компаний. На сегодняшний день за почти полувековую историю создана мощная производственная база, способная обеспечить нефтегазовую отрасль передовыми инновационными технологиями, в том числе по добыче газа с использованием подводных комплексов и укладке глубоководных трубопроводов.

Важными условиями норвежского правительства в рамках сотрудничества с иностранными компаниями является обучение норвежского персонала и локализация производства в Норвегии, уровень которой сегодня составляет $95 \%$. В результате треть норвежского экспорта представлена инновационными технологиями и соответствующим оборудованием для нефтегазовых шельфовых проектов. Норвежские компании владеют весомой долей международного рынка подводного и бурового оборудования, плавучих систем нефтедобычи, хранения, транспортировки и прочих услуг по добыче углеводородов на шельфовых месторождениях.

В течение последних двух десятилетий Норвегия тратила средства не только на открытие новых месторождений, но и на совершенствование технологий увеличения извлечения нефти на эксплуатируемых промыслах. В результате коэффициент извлечения нефти на шельфовых промыслах Северного моря был поднят до 0,68 , что является лучшим показателем в мире [168].

Действующая с 2001 г. Национальная стратегия «Нефть и газ в XXI веке» определила для норвежской промышленности восемь целевых направлений научно-технического прогресса:

- интегрированное производство и управление разработкой пласта в реальном времени;

- подводная обработка и транспортировка добытого из недр углеводородного сырья;

- глубоководная технология добычи;

- газовые технологии;

- разработка экологических технологий извлечения углеводородного сырья;

- комплексное изучение и детальная разведка месторождений с построением трехмерных структурных моделей высокого разрешения, обеспечивающих цифровизацию и автоматизацию управления эксплуатацией «интеллектуальных» добычных комплексов типа smart wells;

- экономически эффективное направленное бурение;

- совершенствование технологий нефтеизвлечения.

Особого внимания требует изучение опыта Норвегии в создании уникальной модели сотрудничества нефтегазовых компаний, научно-исследовательских учреждений и поставщиков оборудования и услуг, объединённых в норвежское партнёрство по энергетике Norwegian Energy Partners (NORWEP) [169]. Поддержку компаниям, которые осуществляют инвестиции в инновационные программы и НИОКР, оказывает Королевский научно-исследовательский совет Норвегии. Проекты в промышленности финансируются по схеме SkatteFUNN, предусматривающей льготное налогообложение. 
Следует изучить и использовать опыт применения Норвегией системы льгот SkatteFUNN для создания и развития собственной промышленности, стимулирования разработки инновационных технологий и соответствующего оборудования для реализации арктических шельфовых месторождений. SkatteFUNN является правительственной программой, призванной стимулировать исследования, разработки и реализацию технологий за счёт налогового кредита и вычета из корпоративного налога компании. Чтобы иметь право подать заявку на участие в SkatteFUNN, компания должна показать стремление к разработке нового или улучшенного продукта - проект должен генерировать новые знания, навыки и возможности внутри компании [170].

Bce проектные предложения, поступающие в программу SkatteFUNN, анализируются и оцениваются экспертами Королевского научноисследовательского совета. Чтобы рассчитывать на получение льгот и стимулов, компания-претендент должна утвердить проект, одобренный советом.

Учёт норвежского опыта рационального распоряжения имеющимися национальными ресурсами в сочетании с оптимальным использованием разработок зарубежных компаний для создания промышленности, способной производить лучшее в мире нефтегазовое оборудование, может стать одной из предпосылок для освобождения от импортозависимости российских операторов, осваивающих арктический шельф.

Меры поддерживающего направления применяются для сохранения и развития потенциала отечественного производства, его модернизации и перевооружения, разработки новых инновационных технологий и соответствующего оборудования. [171] В рамках Федерального закона «О промышленной политике в Российской Федерации» [172] предусматриваются следующие меры поддержки развития.

1. Финансовая поддержка. В рамках развития импортозамещающей деятельности при добыче углеводородов на арктическом шельфе необходимо:

- дополнение и расширение перечня приоритетных направлений гражданской промышленности, которым предоставляется субсидирование процентной ставки на реализацию новых инвестиционных проектов и субсидирование части затрат финансирования НИОКР в рамках постановлений правительства от 3 января 2014 г. № 3 [173] и от 30 декабря 2013 г. № 1312 [174];

- создание специального государственного фонда поддержки проектов (финансовая поддержка в форме займов, грантов, взносов в уставный капитал, финансовой аренды и т. д.).

2. Информационно-консультационная поддержка. В качестве примера такой поддержки можно назвать совместные действия Федерального Собрания Российской Федерации, федеральных и региональных органов исполнительной власти, Российской академии наук и МОО «Ассоциация полярников» в организации Международного конкурса научных, научно-технических и инновационных разработок, направленных на развитие и освоение Арктики и континентального шельфа. Представляется актуальным учитывать показатель «импортозамещение» при выставлении итоговых оценок работам и ввести в данный конкурс номинацию и специальный приз за лучший проект в области импортозамещения.

3. Поддержка развития кадрового потенциала. Разработка и внедрение безопасных технологий добычи нефти и газа в экстремальных климатических 
условиях Арктики формирует новые запросы к подготовке специалистов. При этом коммерческий интерес максимизации прибыли в ближайшей перспективе входит в противоречие с необходимостью вклада в образование квалифицированных специалистов на долгосрочную перспективу [175].

Необходимо формирование государственного заказа для средних специальных и высших учебных заведений на подготовку квалифицированных кадров по многим направлениям, в том числе по геологии, нефте- и газодобыче, специалистов в области арктического судовождения и др. При этом обучающихся необходимо обеспечить опытом полевых работ, например, допускать молодых специалистов к стажировкам в составе буровых и сейсморазведочных партий.

Важно сформировать систему мер, направленных на привлечение ведущих ученых страны и специалистов нефтедобывающих компаний к участию в учебном процессе и научных исследованиях, проводимых для разработки инновационных проектов по освоению арктического шельфа. Органам власти регионов Арктики следует разработать и реализовать программы по содействию государственно-частному партнёрству как механизму интеграции образования, науки и бизнеса [176].

4. Поддержка внешнеэкономической деятельности. Необходимо учесть, что появившиеся отечественные импортозамещающие технологии и оборудование должны иметь качество на уровне или выше мировых аналогов, что позволит им продаваться как на внутреннем, так и на внешнем рынках. Через использование инструментария торговых представительств Российской Федерации в иностранных государствах необходимо оказывать поддержку предприятиям, занятым импортозамещающей деятельностью во внешнеэкономической сфере, по следующим направлениям:

- содействие предприятию в доступе на зарубежные выставочноярмарочные мероприятия;

- поддержка выездов бизнес-миссий предприятий за рубеж;

- распространение информации о продукции предприятий в иностранных государствах;

- поиск потенциальных иностранных партнеров;

- консультационная поддержка (предоставление информации об ограничениях и нормах, регулирующих поставку продукции и услуг, разъяснение вопросов ведения бизнеса, отраслевых правил и правового регулирования в стране пребывания и др.);

- оказание содействия в поиске источников финансирования внешнеэкономических сделок и др.

Нельзя не отметить комплексность проблемы импортозамещения при освоении арктического шельфа. Системное решение такой проблемы невозможно без реорганизации всей отраслевой науки, совершенствования системы подготовки специалистов, реорганизации или создания новых современных проектно-конструкторских институтов [177].

Следует отметить, что в отечественной научной литературе отсутствует однозначное и общепринятое определение емкого и многогранного понятия «импортозамещение». Характерная для импортозамещения динамичность и неравномерность предполагает периодический пересмотр и систематизацию 
параметров для его регулирования. В этом плане необходимо четкое определение набора индикативных признаков для классификации процессов импортозамещения с учетом основных свойств и характеристик объекта.

Авторами под классификацией понимается «разделение множества объектов на классификационные группировки по сходству и различию на основе определенных признаков в соответствии с принятыми правилами» [178].

Для классификации экономических объектов возможно применение двух основных методов - иерархического и фасетного. По причине несвязанности признаков между собой и параллельного разделения множества параметров на независимые классификационные группировки большинство существующих наборов признаков классификации импортозамещения составлены на основе фасетного метода [179]. Несмотря на гибкость, возможность регулировать число признаков и группировок, увеличивать информационную емкость путем выделения общих и частных классификационных группировок, этот метод не позволяет выделить общность и различия между объектами в разных классификационных группировках.

В работе [180], опирающейся на фасетный метод, подразумевающий параллельное разделение множества объектов на независимые классификационные группировки, в качестве индикативных признаков классификации импортозамещения при реализации проектов по освоению шельфа Российской Арктики предложены: геологоразведка, производство и доставка инновационного оборудования, материалов и товаров жизнеобеспечения, добыча углеводородов, транспортировка продукции.

Геологоразведка. Как уже отмечалось, арктический шельф России отличается низкой степенью разведанности. Так, уровень разведанности порядка $20 \%$ для шельфа Баренцева и Карского морей можно считать неплохим результатом по сравнению с шельфом морей Лаптевых, Восточно-Сибирского и Чукотского, где разведанность находится практически на нулевом уровне. Необходимо принять во внимание и высокую, порядка 85 \%, долю иностранных технологий, используемых в геологоразведке арктического шельфа [181].

В этой ситуации правительством РФ активно продвигается программа по созданию отечественных импортозамещающих технологий и средств геологоразведки. Так, Министерством промышленности и торговли выделены значительные финансовые средства на реализацию проектов по созданию геолого-разведочного оборудования для работ на шельфе, в том числе донных сейсмостанций, комплекса электроразведки, сейсморегистрирующего комплекса и сейсмокос. Также отмечается активное сотрудничество с заинтересованными лицами Фонда развития промышленности при реализации проектов по развитию технологий геологоразведки в Арктике. При успешной реализации всех этих проектов возможно формирование отечественного комплекса для геологоразведки арктического шельфа [182].

Производство и доставка инновационного оборудования, материалов $и$ товаров жизнеобеспечения. Федеральный закон № 460-Ф3 «О внесении изменений в Кодекс торгового мореплавания Российской Федерации и признании утратившими силу отдельных положений законодательных актов Российской Федерации», подписанный президентом России 29 декабря 2017 г., значительно расширяет перечень видов деятельности, на которые у судов под российским флагом имеются преимущества на морских пространствах России. В 
частности, речь идёт о лоцманской проводке, карантинном, санитарном и других видах контроля, защите и сохранении морской среды во внутренних морских водах и (или) в территориальном море страны.

В долгосрочной перспективе осуществление этого закона послужит базой для роста объемов морских перевозок, укрепления позиций российских судоходных компаний. Также создадутся дополнительные возможности для обновления торгового флота за счет локализации высокотехнологичного судостроения, что позволит снизить стоимость доставки оборудования и материалов в места добычи и перевалки продукции нефтегазовых арктических промыслов.

Добыча углеводородов. При разработке и реализации технологий добычи нефти и газа на шельфе Арктики необходимо принимать во внимание множество рисков, основные из которых:

- низкая изученность большей части акватории;

- возможные экологические катастрофы, в том числе аварии с разливом нефти;

- неопределенность долгосрочных мировых цен на углеводороды.

В рамках федеральной целевой программы «Развитие гражданской морской техники» правительством России и крупнейшими представителями бизнеса на базе предприятий $\mathrm{AO}$ «Объединенная судостроительная корпорация» предусмотрено выполнение работ по импортозамещению.

Минпромторгом РФ для создания российских образцов оборудования для работы на шельфе создан механизм отбора научно-исследовательских и опытно-конструкторских работ, реализуемых в дальнейшем за счет финансирования из бюджетных средств. Например, в 2016 г. была одобрена реализация четырнадцати НИОКР, имеющих отношение к системам управления, устьевому оборудованию, фонтанной арматуре и компонентам подводных добычных комплексов.

Большое значение приобретает государственная программа «Развитие судостроения и техники для освоения шельфовых месторождений на 2013-2030 годы» и ее подпрограмма «Развитие технологического потенциала гражданского судостроения и техники для освоения шельфовых месторождений». Стратегической целью госпрограммы декларируется реализация прорывных разработок, импортозамещение и локализация производства судов и оборудования для освоения шельфовых месторождений [183]. Основным мероприятием при реализации госпрограммы является создание ПАО «НК “Роснефть"» в Приморском крае промышленного судостроительного кластера «Звезда», предназначенного для постройки судов и оборудования для освоения углеводородных месторождений шельфа Арктики.

Освоение арктических запасов нефти и газа невозможно без морских буровых платформ, которые ранее в основном приобретались или арендовались за рубежом. В этом плане примечателен опыт создания и работы нефтедобывающей платформы «Приразломная». Строительство платформы происходило в Северодвинске и Мурманске с дальнейшей транспортировкой на месторождение. Следует отметить, что в основе производственного комплекса находится опыт ведущих американских, канадских и норвежских нефтегазовых компаний, которые уже несколько десятилетий ведут добычу в подобных 
природно-климатических условиях. На данном примере можно утверждать, что структуры отечественного промышленного, ресурсного и научно-технического сообщества способны скоординировать свои усилия и решить поставленные перед ними задачи при эффективной поддержке государства.

Транспортировка углеводородов. Важнейшим стимулом для развития импортозамещения в сфере перевозки углеводородов может служить изменение законодательства, предусматривающее запрет иностранным судам транспортировать по Северному морскому пути углеводороды, добытые в Российской Арктике. Такая мера повысит значимость и востребованность судов, построенных в России, или позволит использовать существующие суда иностранного производства под государственным флагом РФ до конца сроков эксплуатации. В то же время необходимо предусмотреть возможность эксплуатации судов серии арктических танкеров-газовозов класса $\operatorname{Arc7}$ для транспортировки сжиженного газа проекта «Ямал СПГ» из порта Сабетта.

Запрет иностранным судам транспортировки углеводородов по Северному морскому пути даст толчок развитию отечественного судостроения и различным отраслям экономики, в первую очередь металлургической. Однако необходимо отметить, что импортозамещение электронных систем и двигателей на современных танкерах, к сожалению, является вопросом долгосрочной перспективы.

Рост перевозок углеводородов по Северному морскому пути заставляет осуществлять и серьёзную переоценку айсберговой опасности в Западной Арктике. Значительная часть перспективных судоходных маршрутов будет проходить в высокоширотных районах Северного Ледовитого океана, где вероятность встречи с айсбергами сильно возрастает [65]. К одной из главных задач по обеспечению промышленной и экологической безопасности в ЕвроАрктическом регионе необходимо отнести формирование эффективной системы геофизического и спутникового контроля движения айсбергов в Баренцевом и Карском морях, возможно, с использованием столетнего опыта аналогичной службы в прибрежной зоне Северной Америки.

Деятельность судоводителей по оптимизации транспортировки не принимает во внимание риск столкновения с айсбергом на некоторых участках высокоширотных маршрутов, особенно если они пролегают рядом с архипелагами, покрытыми ледовыми куполами с многочисленными выводными ледниками, разгружающимися в акваторию моря. Отчасти такое пренебрежение является следствием бытующего представления, что серьезная айсберговая опасность имеет отношение только к гигантским ледникам Гренландии, обеспечивающей огромный айсберговый сток в воды Северной Атлантики. Только по «Аллее айсбергов» в год дрейфует до 40000 айсбергов, передвигающихся с севера на юг, где они могут подхватываться теплыми водами Гольфстрима и приплывать в акваторию Баренцева моря.

Естественно, что площади ледовых куполов и айсберговый сток на архипелагах Западной Арктики (Шпицберген, Земля Франца-Иосифа, Новая Земля, Северная Земля) значительно уступают Гренландии [184]. Ориентировочно численность такой Карско-Баренцевоморской группы айсбергов можно оценить в 90 тыс. штук, при этом часть из них потенциально опасна для судов и инженерно-технических сооружений на шельфе. Однако в настоящее время не создано специальных служб, которые следили бы за 
состоянием ледовых покровов на арктических архипелагах и контролировали бы калвинг (айсбергообразование) на кромках выводных ледников.

Развитие импортозамещения в процессе освоения арктического шельфа по предложенным признакам классификации (геологоразведка, доставка оборудования и материалов, добыча и транспортировка углеводородов) будет способствовать снижению рисков и созданию синергетического эффекта при разработке и внедрении отечественного импортозамещающего оборудования. Кроме того, это позволит легче выявлять существующие и потенциально возможные проблемы импортозамещения, оптимизировать инструментарий их решения и в конечном итоге повысить эффективность мер импортозамещающей политики освоения шельфовых месторождений Арктики.

Для формирования политики импортозамещения был принят целый ряд нормативно-правовых актов $[185,186]$. В качестве объекта секторальных ограничений был выбран первый (и пока единственный) проект по добыче нефти на арктическом шельфе РФ - «Приразломное», а также проекты, находящиеся на стадии геологоразведки, принадлежащие группе компаний ПАО «Газпром нефть» и ПАО «НК “Роснефть”», способные стать новыми точками роста нефтедобычи в средне- и долгосрочной перспективах.

Освоение арктического шельфа - новое направление в деятельности российского нефтегазового комплекса. Несмотря на накопленный значительный опыт в освоении береговых месторождений, прокладке десятков тысяч километров газо- и нефтепроводов, освоение морских углеводородных месторождений Арктики - беспрецедентно новое в техническом, технологическом и организационном плане направление работы. До августа 2014 г. российские комплектующие составляли лишь незначительную часть применяемого на арктических промыслах оборудования, не относящегося к разряду высокотехнологичного. Антироссийские санкции в части поставок современного оборудования для шельфовых проектов в Арктике разрушили успешное партнерство российских операторов с западными компаниями и нанесли существенный ущерб экономическим интересам ряда зарубежных энергетических компаний: американской ExxonMobil, итальянской Eni и норвежской Statoil, каждая из которых имела подписанные соглашения о разработке перспективных участков в российской зоне арктического шельфа. Действующие соглашения были расторгнуты, несмотря на очевидные успехи в совместной работе на российском шельфе: так, совместная работа по строительству поисково-оценочной скважины российской нефтяной компанией «Роснефть» и американской ExxonMobil в Карском море на структуре «Университетская» привела к открытию крупного нефтяного месторождения, получившего символичное название Победа.

Иностранным поставщикам оборудования категорически запрещено поставлять оборудование на российские арктические проекты под угрозой санкций со стороны правительств государств, вплоть до банкротства предприятий и уголовного преследования руководителей. Это коснулось и возможности поставок оборудования через «третьи» страны, если устанавливалось, что конечным бенефициаром являются компании, имеющие отношение к реализации российских проектов в Арктике. Некоторым российским энергетическим компаниям был закрыт доступ к иностранному рынку капитала, вследствие чего корпорации лишились возможности 
кредитования и размещения долговых бумаг на срок выше 30 дней. Ситуация усугублялась отсутствием в указанный период в России технологий, соответствующего оборудования и материалов, а также технических средств для выполнения работ на шельфе и их обеспечения, в том числе буровых установок для проведения геолого-разведочных и добычных работ, судов обеспечения, вертолетов в оффшорном исполнении для организации доставки и ротации персонала, а также аппаратов подводного дистанционного управления и контроля.

Очевидно, что введенные секторальные ограничения повлияли на российские проекты по разведке и добыче углеводородов в Арктике - часть проектов по разведке, активно развивавшихся до 2014 г., были приостановлены. Следует отметить, что санкции не оказали критического влияния на реализацию проекта по добыче нефти в промышленных объемах. Так, в декабре 2013 г. месторождение Приразломное было введено в промышленную эксплуатацию, а в апреле 2014 г. была отгружена первая партия нефти с одноименной платформы. Приразломное - единственное действующее месторождение на арктическом шельфе России. Его нефть, получившая название Arctic Oil (ARCO), имеет высокое содержание битумов и низкий показатель коксового остатка. Также за счет низкого содержания парафина тяжелая арктическая нефть хорошо транспортируется и содержит большое количество фракций, используемых для производства масел. Эта нефть прекрасно подходит для нефтеперерабатывающих заводов северо-запада Европы. В настоящее время осуществлена отгрузка 120 танкеров с нефтью, включая отгрузку в суровых ледовых условиях. Для этого были использованы специально спроектированные для таких условий танкеры ледового класса «Михаил Ульянов» и «Кирилл Лавров».

С момента введения санкций энергетические предприятия начали масштабную работу по поиску новых поставщиков, «открыв двери» российского шельфа для восточных компаний, ранее широко не участвовавших в российских проектах. Это позволило сохранить возможность реализации программ развития шельфовых проектов на высоком технологическом уровне и сократить до минимума корректировку лицензионных обязательств российских госкомпаний.

Важнейшим моментом работы в условиях секторальных ограничений стало развитие российского национального сервисного рынка поставщиков. В каждой из энергетических компаний России были сформированы собственные программы импортозамещения, направленные на взаимодействие с отечественной промышленностью.

Стоит отметить, что, несмотря на существовавший скептицизм критиков, реализованные к настоящему времени программы импортозамещения, инициированные правительством РФ и российскими энергетическими компаниями, дали осязаемые результаты. Так, например, в ПАО «Газпром нефть» выделены основные направления, по которым осуществляются поддержка и расширение отечественной производственной базы [187]. В рамках данных направлений отечественным производителям со стороны компании и государства оказывается всесторонняя поддержка в освоении новых видов продукции и технологий. Кроме того, рассматривается модель создания совместных предприятий, а также локализации на территории России производственных мощностей ведущих зарубежных производителей. В рамках 
этих направлений стоит отметить: катализаторы для нефтехимии и нефтепереработки, компрессоры и насосы, необходимое оборудование для сейсморазведочных работ и сопровождения горизонтального и наклоннонаправленного бурения.

Со стороны государства активно поддерживается стимулирование производства инновационных товаров: формируется законодательная база, совместно с энергетическими компаниями и министерствами разработаны дорожные карты для замещения импорта оборудования и критичных компонентов. ПАО «Газпром нефть» предложила уникальный механизм «Покупай российское», заключающийся в государственном субсидировании покупателю разницы в ценах и платы за риск в ходе приобретения пилотных партий новой продукции, изготовленной на территории РФ. Данный механизм работает следующим образом: государство компенсирует до 20 \% стоимости продукции покупателю отечественных разработок в случае, если данная продукция дороже импортной или ее применение сопряжено с рядом технологических рисков.

В 2016 г. Министерством промышленности и торговли РФ были объявлены конкурсы по ряду опытно-конструкторских работ (ОКР). Победителями определены следующие компании:

- ОКР «Геленаполненная коса» - АО «Концерн “Океанприбор”»;

- ОКР «Местоположение» и «Сейсмокоса» - $\mathrm{AO}$ «Акустический институт имени академика Н. Н. Андреева»;

- ОКР «Селекция» - Институт океанологии имени П. П. Ширшова РАН;

- ОКР «Сейсмотомография» - АО «Научно-производственное предприятие “Авиационная и морская электроника”».

По результатам выполнения первых двух программ созданы регистрирующий комплекс и механизм управления косой, прошедшие успешные испытания в октябре 2017 г. на сейсморазведочном судне компании «МАГЭ».

Следует отметить, что задачей государственного регулирования является не только организация разработки российских инновационных технологий, но и формирование основ политики импортозамещения, включая принципы функционирования и алгоритм её реализации [188]. Как представляется авторам, эта политика должна базироваться на следующих принципах.

1. Принцип нормативно-правового регулирования для комплексного планирования освоения месторождений [189]. Для формирования политики импортозамещения президентом РФ 14 мая 2014 г. подписан Перечень поручений о дополнительных мерах по стимулированию экономического роста, который содержит ряд требований к правительству РФ, в том числе по разработке и утверждению планов содействия импортозамещению в промышленности [185]. В ответ на данное поручение правительство Российской Федерации своим распоряжением от 30 сентября 2014 г. № 1936 утвердило План содействия импортозамещению в промышленности, согласно которому Министерство промышленности и торговли Российской Федерации утвердило отраслевые планы импортозамещения. Одним из таких документов является План мероприятий по импортозамещению в отрасли нефтегазового машиностроения Российской Федерации, где среди прочих направлений 
деятельности указано и направление «Технологии и оборудование, используемые для реализации шельфовых проектов» [186].

Принята государственная программа Российской Федерации «Развитие судостроения и техники для освоения шельфовых месторождений на 2013-2030 годы», целями которой являются создание более 400 и внедрение более 300 технологий по созданию судов и техники для освоения шельфовых месторождений с учетом необходимости импортозамещения.

Также Министерством экономического развития Российской Федерации 10 марта 2016 г. издан Приказ № 116 «Об утверждении методических рекомендаций по подготовке региональных планов по импортозамещению». Составленные на данной основе документы определяют основные показатели и ключевые мероприятия, направленные на увеличение доли отечественных поставщиков товаров в цепочках поставщиков регионального уровня, организацию производства импортозамещающей продукции. Разрабатываемые региональные планы импортозамещения также могут содержать положения, способствующие реализации стратегии импортозамещения при добыче углеводородов на арктическом шельфе. Так, в Плане по импортозамещению Мурманской области указаны мероприятия по содействию созданию и развитию технологического кластера обеспечения шельфовой добычи в Арктике.

Необходимо отметить в сфере импортозамещения и деятельность непосредственных разработчиков шельфовых месторождений Российской Арктики, например, создание ПАО «Газпром нефть» Департамента технологических партнерств и импортозамещения с целью взаимодействия с различными организациями, осуществляющими разработку инновационных технологий и поставку оборудования.

2. Принцип разработки и реализации научно обоснованного инструментария с учетом исследований достижений зарубежного и отечественного опыта. Крайне важно, чтобы управленческие действия осуществлялись на базе применения научных методов и подходов, основывались на принципах науки и отвечали их требованиям. Это позволит повысить уровень организованности процессов импортозамещения, обеспечит более рациональное использование ресурсов за счет применения научных исследований и достижений.

3. Принцип системности, показывающий, что освоение углеводородных ресурсов представляет собой сложную экономическую систему. В процессе реализации стратегии необходимо учитывать системный характер функционирования и развития нефтегазовой отрасли, а также весь комплекс правовых, экономических, производственных и информационных отношений в хозяйственной деятельности в Арктике [190, 191].

Имеется системная взаимозависимость освоения арктических углеводородных месторождений с развитием Арктической транспортной системы и ледокольного флота, степенью распространения ледовых полей Северного Ледовитого океана и учётом такой не очевидной на первый взгляд опасности, как айсберговая [65].

Наряду с этим важно понимать, что освоение углеводородных ресурсов Арктики не может определяться только лишь законами рынка. Необходимо принятие во внимание целого ряда некоммерческих интересов населения, проживающего на арктической территории, вопросы экологосбалансированности и устойчивого развития территорий. 
4. Принцип целенаправленности, предполагающий постановку целей перед федеральными и региональными органами власти. При этом поставленная цель должна быть реальной, достижимой за счёт активных действий и рациональной системы управления. Так, на сегодняшний момент в Плане мероприятий по импортозамещению в отрасли нефтегазового машиностроения Российской Федерации показано, что в технологическом направлении «Технологии и оборудование, используемые для реализации шельфовых проектов», доля импорта в 2014 г. составляла 80-90\%. Целью выполнения мероприятий плана является снижение доли импорта к 2020 г. до уровня $60-70 \%$ [186].

5 . Принцип инновационности, направленный на замену импортных технологий отечественными, что возможно при наличии определенных научнотехнических, организационных и социальных условий [192-194]. Добыча углеводородных ресурсов на арктическом шельфе потребует широкого внедрения промышленного аутсорсинга и развития промышленного сервиса. За счет высокого уровня технологической оснащенности и специализированного характера труда малые и средние инновационные предприятия способны содействовать модернизации производства, использованию современных материалов и инновационных технологий $[195,196]$.

6. Принцип эффективности и экономичности, предусматривающий разработку наиболее рационального способа реализации стратегии импортозамещения. Это является важным условием построения и функционирования системы стратегического управления развитием отрасли, нацеленной на импортозамещение. Только наличие показателей эффективности позволит осуществлять контроль и мониторинг процесса реализации стратегии импортозамещения. Для проведения расчетов эффективности реализации политики импортозамещения возможно использование экономико-математической модели, построенной на упрощенных уравнениях межотраслевого баланса с инвестиционным блоком на основе модели «затраты - выпуск», предложенной лауреатом Нобелевской премии В. Леонтьевым. В качестве критериальных показателей могут быть использованы валовая добавленная стоимость, суммарные инвестиции и др., позволяющие определять экономический эффект от реализации стратегии [197].

7. Принцип, направленный на повышение качества и конкурентоспособности продукции для освоения шельфовых месторождений. Основой данного принципа является ясное понимание того, что целью импортозамещения является не полная самодостаточность отрасли в средствах производства, а ориентация на создание производственной основы, способной обеспечивать страну конкурентоспособной на мировом рынке продукцией. В этом плане при реализации стратегии большой проблемой станет борьба с фальсификацией нефтегазового оборудования. При активном стимулировании импортозамещения возможно ожидать, что рынок машиностроительной продукции для разработки арктических месторождений рискует быть заполненным низкокачественной продукцией как отечественного, так и зарубежного производства.

8. Принцип информативности, предусматривающий обеспечение современной информацией при освоении углеводородных месторождений на арктическом шельфе. Для реализации политики импортозамещения при добыче углеводородных ресурсов на арктическом шельфе важна информация о ходе процесса, его направленности, формах реализации, об основных качественных 
характеристиках, количественных параметрах и уровнях результативности за счет активного использования современных информационных систем и технологий по передаче, обработке и хранению информации. Это позволит устанавливать определенные закономерности, принимать и реализовывать эффективные управленческие решения.

9. Принцип ориентации на высококвалифицированный кадровый потенциал. Очевидно, что без компетентных руководителей и инновационно активных кадров, обладающих способностью к быстрой профессиональной реакции, умеющих принимать самостоятельные компетентные и эффективные решения, генерировать и реализовывать новые идеи, реализация стратегии импортозамещения будет затруднена.

Бывший губернатор Ямало-Ненецкого автономного округа Дмитрий Кобылкин в интервью ТАСС сообщил, что «одно рабочее место в Арктике создает четырнадцать рабочих мест в смежных регионах России» [198]. Очевидно, что реализация арктических проектов импортозамещения обладает мощными мультипликативными и комплексоформирующими эффектами. В этой связи для эффективной реализации проектов импортозамещения необходим целый ряд специалистов инновационной направленности: от производственного персонала до руководителей, обладающих самой высокой компетенцией.

10. Принцип экологической и промышленной безопасности, предусматривающий, прежде всего, сохранение уязвимой экосистемы и предотвращение потенциальных разливов нефти.

Разработанные принципы политики импортозамещения при освоении углеводородов на арктическом шельфе позволяют сформулировать алгоритм ее реализации, т. е. совокупность последовательных действий, основные из них следующие [199].

1. Мониторинг динамики и анализ структуры импорта, формирование перечня товаров и технологий, подлежащих импортозамещению. Для понимания всей широты возможностей импортозамещения и их структуризации необходима разработка системы классификационных признаков.

2. Ранжирование импортозамещающих проектов по степени готовности к реализации и по степени приоритетности.

3. Организация работы с компаниями-операторами по включению в их технические задания на закупку требования о преимущественной поставке материалов, оборудования и технологий российского производства (при условии наличия соответствующих российских аналогов).

4. Совместная разработка дорожных карт по созданию импортозамещающей продукции российскими производителями, энергетическими компаниями и государственными отраслевыми ведомствами, позволяющая согласовать этапы выпуска новых видов продукции.

В этом плане необходимо отметить опыт работы ПАО «Газпром нефть», которое в целях оптимизации взаимодействия с технологическими партнёрами определило и широко распространило свой Перечень технологий и оборудования, которые оно готово приобретать у отечественных производителей.

5. Содействие организациям, выпускающим или планирующим выпускать импортозамещающую продукцию путем предоставления государственного финансирования трехсторонних контрактов, заключенных между российскими производителями, энергетическими компаниями и государственными отраслевыми 
ведомствами (на примере ПАО «Газпром нефть» можно увидеть, что подобные контракты были профинансированы в 2016-2017 гг. на сумму, превышающую 2 млрд руб.).

6. Формирование современной информационной базы данных и знаний о принципиальной возможности создания импортозамещающей продукции.

7. Создание системы совершенствования кадрового обеспечения для высокоэффективного освоения арктического шельфа и развития сопутствующих отраслей экономики за счет повышения гибкости арктической системы высшего и среднего профессионального образования, оперативного реагирования на изменение спроса на рынке труда и сокращения потребностей в работниках определенного уровня и специализации [200].

8. Анкетирование поставщиков и потребителей импортозамещающей продукции и определение необходимых дополнительных мер поддержки для производителей импортозамещающей продукции и разработчиков инновационных технологий.

9. Разработка научно обоснованных рекомендаций по совершенствованию стратегии импортозамещения для эффективного освоения углеводородов на арктическом шельфе. 


\section{ЗАКЛЮЧЕНИЕ}

В работе выполнен анализ факторов, препятствующих широкому применению инновационных технологий и наилучших практик в ходе освоения месторождений углеводородов на арктическом шельфе Российской Федерации. В их числе, прежде всего, принципы формирования рыночных цен на добываемую продукцию, тарифы естественных монополий, санкции западных стан, недостаточное инновационно-технологическое развитие экономики Российской Арктики. Отмечено, что, несмотря на приостановку международного сотрудничества по проектам в Арктике ввиду санкционных ограничений, российские компании продолжают планомерно вести геологоразведочные работы на лицензионных участках.

На основании анализа различных методик предложена интегральная методика оценки инвестиционной привлекательности арктических проектов, использующая наиболее важные показатели деятельности компаний-операторов: финансовую независимость и стабильность, оборачиваемость активов, платежеспособность. Выполнено ранжирование ведущих операторов нефтегазового сектора Арктической зоны Российской Федерации по инвестиционной привлекательности и прослежена эволюция рейтингов во времени в период введения санкционных ограничений. Выявлено, что только шесть предприятий из тринадцати в 2014 и 2018 гг. сохранили рейтинги: ПАО «Сургутнефтегаз» — высокую инвестиционную привлекательность, ОАО «Севернефтегазпром», ПАО «НОВАТЭК» и АО «Мурманоблгаз» - умеренную привлекательность, АО «Сахатранснефтегаз» и ОАО «Тарманское западное» - низкую привлекательность. Два предприятия (АО «Алроса-Газ» и АО «Сибнефтегаз») понизили рейтинги в 2018 г. по отношению к 2014 г. Пять предприятий (АО «Газпром газораспределение Север», ОАО «Нефтебурсервис», ОАО «Варьеганнефть», ОАО «Обьнефтегазгеология», ОАО «Славнефть-Мегионнефтегаз») показали положительную тенденцию роста инвестиционной привлекательности.

Интегральная методика и проведенная на ее основе оценка арктических предприятий нефтегазового комплекса позволит инвесторам получить дополнительные данные для принятия решений о реализации инвестиционных проектов рассматриваемых компаний. Требуется проведение дальнейших исследований по разработке научно обоснованных методических основ оценки инвестиционной привлекательности промышленных предприятий, особенно в специфических условиях Арктики, финансового кризиса и продолжающихся санкций западных стран.

Представлен краткий обзор основных «освоенческих» проектов в Арктической зоне Российской Федерации, за счет которых может многократно увеличиться грузопоток на трансарктических морских коммуникациях между Россией, ЕС и Юго-Восточной Азией: проект освоения ресурсов ЮжноТамбейского газоконденсатного месторождения «Ямал СПГ»; освоение ресурсов нефтегазоконденсатных месторождений Гыданского полуострова «Арктик СПГ-2»; освоение нефтяных месторождений западного побережья Обской губы с круглогодичным вывозом сырой нефти через уникальный морской терминал «Ворота Арктики»; освоение Пайяхской группы нефтяных месторождений на Таймыре с локализацией грузового терминала «Таналау»; освоение нефтяных ресурсов с использованием морской ледостойкой 
стационарной платформы «Приразломная»; освоение Таймырского угольного бассейна со строительством в районе поселка Диксон в устье Енисея двух глубоководных портовых терминалов «Чайка» и «Север»; обеспечение круглогодичного вывоза готовой продукции горно-металлургической компании ПАО «Норильский никель»; освоение и вывоз рудных концентратов с Павловского месторождения.

Предложен комплекс мер по уменьшению рисков транспортировки углеводородного сырья по высокоширотным трассам Северного морского пути, в том числе: формирование системы гидрометеорологической информации, создание наземного комплекса Арктической системы геофизического мониторинга опасных динамических процессов в природной среде и техносфере в Баренцевом и Карском морях, системы автоматической идентификации судов, формирование «айсбергового патруля» в Карско-Баренцевоморском секторе высокоширотной трансарктической магистрали, целевая государственная поддержка научных исследований, направленных на изучение масштабов и механизмов разрушения криолитосферы под воздействием потепления климата и роста техногенного стресса.

Намечены приоритетные направления совершенствования природоохранной деятельности и экологического воспитания в районах интенсивной индустриализации и урбанизации Российской Арктики, основные из которых: совершенствование законодательной базы; активизация интеграционных процессов; повышение эффективности рационального комплексного освоения минерального сырья; ускорение перехода на пятый и шестой технологические уклады; обновление основных фондов; создание необходимых инфраструктурных объектов; увеличение количества реализуемых программ эколого-биологической направленности; развитие учебно-опытных участков для организации практических занятий экологического воспитания детей; совершенствование системы информационно-коммуникационного обеспечения; эффективное управление энергоснабжением и энергосбережением.

Рассмотрена проблематика снижения или предотвращения рисков при строительстве мегасооружений на территориях с активным проявлением опасных эндогенных флюидодинамических процессов в вечной мерзлоте. Показано, что практика строительства на арктическом шельфе сверхкрупных гравитационных платформ обгоняет научно-методическую обеспеченность хозяйственных действий. Показано, что недостаточная изученность геомеханики мерзлых грунтов, насыщенных газогидратами метана, и отсутствие технических средств выделения этого типа грунтов в геологическом разрезе промышленных площадок на стадиях инженерных изысканий увеличивают риск проявления опасных разрушительных процессов в ходе эксплуатации нефтегазовых месторождений в Арктической зоне Российской Федерации. В качестве наиболее эффективного подхода в обеспечении промышленной безопасности арктических природно-технических систем предложено создание вокруг них пространственно распределенных групп типа фазовых антенн, состоящих из интегрированных в единую сеть сейсмоакустических и электромагнитных датчиков, непрерывно поставляющих информацию о критических параметрах геофизической среды и импактных зон геомеханического пространства в региональные обрабатывающие центры, способные автоматически осуществлять 
процессинг больших потоков данных и выявлять признаки аномальных нарушений стабильности недр в реальном времени.

Подтверждено концептуальное положение о том, что стратегия природопользования и устойчивое социально-экономическое развитие Арктики должны регламентироваться экологическим императивом, т. е. знаниями о пределах равновесного сосуществования биосферных и техносферных компонентов арктической мегасистемы. Акцентирована необходимость признания нового междисциплинарного научного направления - управление арктической ноосферой, которое создает предпосылки для перехода на проектный метод руководства развитием всего арктического мегарегиона в рамках которого программно-целевое государственное планирование в секторах жизнеобеспечения, экологической безопасности и национальной обороны будет гармонично сочетаться с контролируемой эксплуатацией на рыночных принципах природных ресурсов Арктики.

Исследованы проблемы в области импортозамещения при освоении арктического шельфа. Для обоснования мер государственного регулирования предложены классификационные признаки импортозамещения освоения арктического шельфа, которые позволят систематизировать и установить взаимосвязи между ними, что в конечном итоге даст возможность выявить существующие и потенциальные проблемы, оптимизировать инструментарий их решения и повысить эффективность мер импортозамещающей политики.

Сформулированы принципы формирования политики импортозамещения при освоении месторождений арктического шельфа Российской Федерации, которые охватывают проблемы научной обоснованности, правовой регламентации, системности, адаптивности, инновационного развития, эффективности, экономичности, поддержания и роста уровня качества продукции, информатизации процесса, эффективного использования трудовых ресурсов, а также экологической безопасности.

Разработанные принципы политики импортозамещения при освоении углеводородов на арктическом шельфе позволяют сформулировать алгоритм ее реализации, основные этапы которого - формирование перечня товаров и технологий, подлежащих импортозамещению; ранжирование импортозамещающих проектов по степени готовности и приоритетности; разработка дорожных карт для согласования производства импортозамещающей продукции; предоставление государственной поддержки организациям, выпускающим или планирующим к выпуску импортозамещающую продукцию; создание системы совершенствования кадрового обеспечения для высокоэффективного освоения арктического шельфа и развития сопутствующих отраслей экономики.

Реализация политики импортозамещения при освоении углеводородного сырья на арктическом шельфе России является основой для вовлечения промышленных предприятий, геолого-разведочных и научно-исследовательских организаций в производство инновационных товаров и услуг, а также для улучшения социально-экономического развития территорий Российской Арктики. 


\section{ЛИТЕРАТУРА}

1. Карта арктических месторождений [Электронный pecypc]. URL: http://russiancouncil.ru/arcticdata/\#map=2/-41.82/40.3/0/3857/0/0/3/11111/29 (дата обращения: 30.07.2017).

2. Информационное агентство Arctic info [Электронный ресурс]. URL: http://www.arctic-info.ru/encyclopedia/fields/ (дата обращения: 22.08.2017).

3. Арктический шельф является ключевым резервом углеводородов в мире [Электронный pecypc]. URL: http://www.ngv.ru/news/arkticheskiy_shelf_yavlyaetsya_klyuchevym_rezervo m_uglevodorodov_v_mire/?sphrase_id $=6596454$ (дата обращения: 22.08.2017).

4. Годовой отчет ПАО «Газпром» за 2018 год [Электронный ресурс]. URL: http://www.e-disclosure.ru/portal/files.aspx?id=934\&type=2 (дата обращения: 30.12.2019).

5. Селин В. С., Цукерман В. А., Виноградов А. Н. Экономические условия и инновационные возможности обеспечения конкурентоспособности месторождений углеводородного сырья арктического шельфа. Апатиты: КНЦ РАН, 2008. 267 с.

6. Отгружено товаров собственного производства, выполнено работ и услуг собственными силами (без НДС, акцизов и аналогичных обязательных платежей) по «чистым» видам деятельности (оперативные данные) с 2017 г. [Электронный ресурс]. URL: https://www.fedstat.ru/indicator/58554 (дата обращения: 30.12.2019).

7. Годовая бухгалтерская отчетность ПАО «Газпром» [Электронный ресурс]. URL: $\quad$ http://www.e-disclosure.ru/portal/files.aspx?id=934\&type=3 (дата обращения: 30.12.2019).

8. Годовая бухгалтерская отчетность ОАО «Севернефтегазпром» [Электронный pecypc]. URL: http://www.edisclosure.ru/portal/files.aspx?id=16965\&type $=3$ (дата обращения: 30.12.2019).

9. Годовая бухгалтерская отчетность ПАО «НК Роснефть» [Электронный pecypc]. URL: http://www.e-disclosure.ru/portal/files.aspx?id=6505\&type=3 (дата обращения: 30.12.2019).

10. Годовая бухгалтерская отчетность АО «Сибнефтегаз» [Электронный pecypc]. URL: http://www.e-disclosure.ru/portal/files.aspx?id=6794\&type=3 (дата обращения: 30.12.2019).

11. Годовая бухгалтерская отчетность ПАО «НОВАТЭК» [Электронный pecypc]. URL: http://www.e-disclosure.ru/portal/files.aspx?id=225\&type=3 (дата обращения: 30.12.2019).

12. Годовая бухгалтерская отчетность ПАО «ЛУКОЙЛ» [Электронный pecypc]. URL: http://www.e-disclosure.ru/portal/files.aspx?id=17\&type=3 (дата обращения: 30.12.2019).

13. Годовой отчет ПАО «НОВАТЭК» за 2018 год [Электронный ресурс]. URL: http://www.e-disclosure.ru/portal/company.aspx?id=225 (дата обращения: 30.12.2019).

14. Цукерман В. А., Горячевская Е. С. Оценка финансово-экономической и инновационной деятельности промышленных предприятий Арктики 
минерально-сырьевой направленности // Север и рынок: формирование экономического порядка. 2015. № 4 (47). С. 71-86.

15. Цукерман В. А. О стратегии инновационного развития регионов Севера, связанных с освоением морских ресурсов // Север и рынок: формирование экономического порядка. 2011. № 2 (28). С. 69-72.

16. Савчук В. П., Прилипко С. И., Величко Е. Г. Анализ и разработка инвестиционных проектов. Киев: Абсолют-В: Эльга, 1999. 304 с.

17. Бочаров В. В. Инвестиционный менеджмент. СПб.: Питер, 2002. 151 с.

18. Крейнина М. Н. Анализ финансового состояния и инвестиционной привлекательности акционерных обществ в промышленности, строительстве и торговле. М.: Дело и Сервис, 1994. 256 с.

19. Крылов Э. И., Власова В. М., Егорова М. Г. Анализ финансового состояния и инвестиционной привлекательности предприятия. М.: Финансы и статистика, 2003. 192 с.

20. Конторович С. П. Управление инвестиционной привлекательностью предприятия: Системно-оценочный аспект [Электронный ресурc]. URL: http://www.dissercat.com/content/upravlenie-investitsionnoi-privlekatelnostyupredpriyatiya-sistemno-otsenochnyi-aspekt (дата обращения: 16.05.2019).

21. Быльцов С. Ф. Настольная книга российского инвестора. СПб.: Бизнеспресса, 2000. 512 c.

22. Цукерман В. А. Промышленная, инвестиционная и инновационная политика: энциклопедический словарь. Апатиты: КНЦ РАН, 2009. 181 с.

23. Komkov N. I., Tsukerman V. A., Goryachevskaya E. S. Analysis of the Main Factors of Innovative Development of the Arctic Regions of Russia // Studies on Russian Economic Development. 2019. Vol. 30, No. 1. P. 22-27. DOI: 10.1134/S107570071901009X

24. Tsukerman V. A., Goryachevskaya E. S. On Implementing the Strategy of Scientific and Technological Development of the Russian North and the Arctic // Advances in Economics, Business and Management Research. International Scientific Conference "Far East Con" (ISCFEC 2018). 2019. Vol. 47. P. 814 817. DOI: http://doi.org/10.2991/iscfec-18.2019.198

25. Zharov V. S. The Effect of Innovative Tax Leverage and the Ability to "Quasi Self-Financing" Innovation Activities of Enterprises // 2018 IEEE International Conference "Quality Management, Transport and Information Security, Information Technologies" (St. Petersburg, 24-28 September 2018). P. 185187. DOI: 10/1109/ITMQIS.2018.8524992

26. Gilenko E. V. Stability of money demand in the Russian Economy after the global financial crisis of 2008-2009 // Journal of Reviews on Global Economics. 2018. No. 7. P. 946-952.

27. Sysoeva E., Budilova E., Risin. I. Influence of economic sanctions on the financial resources of Russian organizations // Proceedings of the 27th International Business Information Management Association Conference Innovation Management and Education Excellence Vision 2020: From Regional Development Sustainability to Global Economic Growth, IBIMA 2016. 2016. P. 1145-1156.

28. Tsukerman V. A., Goryachevskaya E. S., Ivanova L. V. On Innovation Activities of Industrial Companies of the North and the Arctic under the Conditions of Resource Restrictions // Proceedings of the 2017 International 
Conference "Quality Management, Transport and Information Security, Information Technologies" (September, 24-30, 2017). St. Petersburg: Publ. Saint Petersburg Electrotechnical University "LETI", 2017. P. 593-597. DOI: 10.1109/ITMQIS.2017.8085893

29. Zharov V. S., Zharov N. V. Problems of management of innovative development of industry in the regions of the Far North // Proc. of the 2018 IEEE Managing the development of large-scale systems (MLSD' 2018), 1-3 Oct. 2018. 2018. № 8551783 .

30. Khokhlova G., Kretova N., Sergeev V. Competitiveness as a factor of the company's investment attractiveness // International Scientific Conference "Investment, Construction, Real Estate: New Technologies and Special-Purpose Development Priorities”, ICRE 2018. 2018. Vol. 212, No. 08019.

31. Ukolov V. F., Rudolph K., Ostrovskaya A. A. Adaptation of the enterprises of the real economy sector to supply chain management and digitalization in the conditions of the development of virtual relations // International Journal of Supply Chain Management. 2019. No. 2 (8). P. 1109-1116.

32. Chazov E. L., Grakhov V. P., Krivorotov V. V., Simchenko O. L. Improving the efficiency of planning as a basis for management the investment activity of an industrial enterprise // Energetika. Proceedings of CIS Higher Education Institutions and Power Engineering Associations. 2019. No. 1 (62). P. 88-10.

33. Fedoseev S. V., Cherepovitsyn A. E., Tsvetkov P. S. Statement and mathematical characterization of the task of assessing the strategic potential of fuel and energy industry of Russia // International Journal of Applied Engineering Research. 2016. No. 11 (16). P. 9002-9006.

34. Cherepovitsyn A., Metkin D., Gladilin A. An Algorithm of Management Decision-Making Regarding the Feasibility of Investing in Geological Studies of Forecasted Hydrocarbon Resources // Resources. 2018. No. 7 (3). P. 47.

35. Marchenko R. S., Cherepovitsyn A. E. Improvement of the quality of calculations using the Monte Carlo simulation method in the evaluation of mining investment projects // Proceedings of the 2017 International Conference "Quality Management, Transport and Information Security, Information Technologies", IT and QM and IS 2017. 2017. P. 247-251.

36. Velnikovskaya A., Sizykh N. Modeling and Assessment of the IT Companies Investment Attractiveness Indicators // Proceedings of 2018 11th International Conference "Management of Large-Scale System Development", 1-3 Oct. 2018. 2018. № 8551880 .

37. Matyash I. V. Investment attractiveness and sustainable growth of telecommunication companies: Value-oriented approach // Economy of Region. 2018. No. 4 (14). P. 1411-1423.

38. Endovitsky D. A., Davnis V. V., Korotkikh V. V. Adaptive trend decomposition method in financial time series analysis // The Journal of Social Sciences Research. 2018. No. 3. P. 104-109.

39. Endovitsky D. A., Durakova I. B. Economic and statistical analysis of nonopposition to changes in the labor market and the educational services market // Studies in Systems, Decision and Control. 2018. No. 135. P. 95-105.

40. Мельничук О. М. Инвестиционная привлекательность металлургической компании: методика оценки // Российское предпринимательство. 2012. № 1 (99). C. $128-135$. 
41. Салютина Т. Ю., Рабовская Л. С. Методические подходы к оценке инвестиционной привлекательности телекоммуникационной компании // Т-СОММ: телекоммуникации и транспорт. 2009. № 3. С. 34-38.

42. Крейнина О. А. Анализ денежных средств предприятия как условие его финансовой устойчивости // Финансовые исследования. 2008. № 4 (21). С. $58-61$.

43. Центр раскрытия корпоративной информации [Электронный ресурс]. URL: http://www.e-disclosure.ru/poisk-po-kompaniyam (дата обращения: 16.05.2019)

44. Комков Н. И., Лазарев А. А., Романцов В. С. Стратегии стран мира в освоении Арктики // Арктическое пространство России в XXI веке: факторы развития, организации управления / под ред. акад. В. В. Ивантера. СПб.: Санкт-Петербургский политехнический университет Петра Великого; издательский дом «Наука», 2016. С. 215-244.

45. Объем перевозок грузов в акватории Северного морского пути [Электронный pecypc]. URL: https://fedstat.ru/indicator/51479 (дата обращения: 30.12.2019).

46. Стратегия развития Арктической зоны Российской Федерации и обеспечения национальной безопасности на период до 2020 года // Арктические ведомости. 2013. № 1 (5). С. 162-182.

47. Комков Н. И., Сутягин В. В., Володина Н. Н. Потребность в продуктах нефтехимии определяет динамику спроса на углеводородное сырье // Процессы глобальной экономики: сб. науч. тр. международной научнопрактической конференции. Санкт-Петербургский Политехнический университет Петра Великого. 2016. С. 127-137 [Электронный ресурс]. URL: http:/elibrary.ru/item.asp?id=27553034 (дата обращения: 25.11.2016).

48. Почему США закупают российский газ вопреки своим же санкциям? // «Русское агентство новостей», выпуск от 31.01.2018 [Электронный pecypc]. URL: http://новости-сша.ru-an.info/новости/почему-сша-закупаютроссийский-газ-вопреки-своим-же-санкциям (дата обращения: 28.07.2018).

49. Вадим Бугаев: мы - уникальный проект для российской экономики // Интернет-ресурс: сетевое издание «Редкие элементы», выпуск от 30.03.2017 [Электронный ресурс]. URL: http://rareearth.ru/ru/pub/20170330/03064.html (дата обращения: 28.07.2018).

50. Арутюнян В. Г., начальник штаба морских операций «Росатомфлота»: Организация круглогодичной навигации на Северном морском пути // Информагентство «Proatom» от 09.11.2017 [Электронный ресурс]. URL: http://www.proatom.ru/modules.php?name=News\&file=article\&sid=7730 (дата обращения: 28.07.2018).

51. «Новатэк» и «Total» подписали соглашение об участии в проекте «Арктик СПГ-2» // Информагентство ТАСС от 24.05.2018 [Электронный ресурс]. URL: http://tass.ru/pmef-2018/articles/5232267 (дата обращения: 28.07.2018).

52. Проект «Приразломное» [Электронный ресурс] // Сайт «Газпром нефть». URL: $\quad$ http://www.gazprom-neft.ru/company/business/exploration-andproduction/new-projects/prirazlomnoe/ (дата обращения: 28.07.2018).

53. Проект «Павловское» [Электронный ресурс] // Сайт АО «Атомредметзолото». URL: http://www.pgrk.armz.ru/project/place/ (дата обращения: 28.07.2018). 
54. Факторный анализ и прогноз грузопотоков Северного морского пути / науч. ред. д. э. н., проф. В. С. Селин, д. э. н. проф. С. Ю. Козьменко. Апатиты: КНЦ РАН, 2015. 335 с.

55. Кириченко А. Про контейнерный транзит по Севморпути [Электронный pecypc] // Информационно-аналитическое агентство SeaNews от 27.10.2017. URL: http://seanews.ru/2017/10/23/про-контейнерный-транзитпо-севморпути/ (дата обращения: 28.07.2018).

56. Лаверов Н. П., Попович В. В., Ведешин Л. А., Коновалов В. Е. Современные подходы и возможности системы освещения обстановки в Арктике в интересах обеспечения безопасного судоходства Северного морского пути // Современные проблемы дистанционного зондирования Земли из космоса. 2017. Т. 14, № 3. С. 141-157. DOI: 10.21046/2070-74012017-14-3-141-157

57. Le Traon P. Y., Ali A., Fanjul E. A et al. The Copernicus Marine Environmental Monitoring Service: Main Scientific Achievements and Future Prosects // Mercator Ocean J. Spec. Issue. 2017. Vol. 56. 101 p.

58. The Svalbard Integrated Arctic Earth Observing System (SIOS). URL: https://sios-svalbard.org/ (дата обращения: 28.07.2018).

59. Носенко Ю. И., Севастьянов Н. Н., Дядюченко В. Н., Полищук Г. М., Асмус В. В. Многоцелевая космическая система «Арктика», перспективы eе создания [Электронный pecypc]. URL: http://d33.infospace.ru/d33_conf/2009_conf_pdf/plenar/Nosenko.pdf (дата обращения: 28.07.2018).

60. Цукерман В. А., Горячевская Е. С. Влияние санкций на комплексное освоение месторождений Арктического шельфа // Россия: тенденции и перспективы развития. Ежегодник. Вып. 12, ч. 3 / отв. ред. В. И. Герасимов. М.: изд. ИНИОН РАН, 2017. С. 158-161.

61. Виноградов А. Н., Виноградов Ю. А., Кременецкая Е. О., Петров С. И. Формирование системы сейсмологического и инфразвукового мониторинга в Западной Арктике в $\mathrm{XX}$ веке и перспективы ее дальнейшего развития // Вестник Кольского научного центра. 2012. № 4. C. $145-163$.

62. Маловичко А. А., Виноградов А. Н., Виноградов Ю. А. Развитие систем геофизического мониторинга в Арктике // Арктика: экология и экономика. 2014. № 2 (14). C. 16-23.

63. Виноградов А. Н., Виноградов Ю. А., Асминг В. Э., Баранов С. В., Петров С. И., Федоров А. В. Инновационные технологии геофизического мониторинга опасных флюидодинамических процессов в криосфере Западной Арктики // Природные ресурсы и комплексное освоение прибрежных районов Арктической зоны: сб. науч. тр. 2-го Арктического форума (Архангельск, 27-29 сентября 2016 г.) / отв. ред. В. И. Павленко. Архангельск: ФИЦ КИА РАН, 2016. С. 70-80.

64. Центр ЕСИМО. URL: http://www.aari.ru/projects/ECIMO/index.php (дата обращения: 28.07.2018).

65. U. S. Coast Guard International Ice Patrol. URL: www.navcen.uscg.gov/IIP (дата обращения: 28.07.2018). 
66. Симаков В. В., Ведешин Л. А., Зеркаль А. Д. Наземно-космический мониторинг ледовой обстановки в Арктике // Исследование Земли из космоса. 2013. № 2. С. 86-87. DOI: 10.7868/S0205961413020127

67. Виноградов А. Н., Цукерман В. А. Айсберговая опасность в Западной Арктике и актуальные задачи по снижению рисков для транспортных коммуникаций и шельфовых промыслов // Север и рынок: формирование экономического порядка. 2017. № 5 (56). С. $115-128 . \quad$ DOI: 10.25702/KSC.2220-802X-5-2017-56-115-128

68. Абрамов В. М., Гогоберидзе Г. Г., Попов Н. Н., Бербуши С. В., Бачиев Р. И. Айсберговая опасность для морской деятельности в Российской Арктике в условиях изменения климата // Информационные технологии и системы: управление, экономика, транспорт, право. 2015. № 2 (16). С. 6-8.

69. Шапошников В. М., Александров А. В., Матанцев Р. А., Ивановская О. Д. Анализ айсберговой опасности на Северном морском пути на примере газовозов // Арктика: экология и экономика. 2017. № 2 (26). С. 76-81.

70. Виноградов А. Н., Виноградов Ю. А., Баранов С. В., Кременецкая Е. О., Петров С. И. Факторы риска, связанные с деградацией криосферы в Западной Арктике, и проблемы геофизического мониторинга // Природные ресурсы и комплексное освоение прибрежных районов Арктической зоны: сб. науч. тр. / отв. ред. В .И. Павленко. Архангельск: ФИЦ КИА РАН, 2016. С. 64-70.

71. Виноградов А. Н. Актуальные задачи геофизического мониторинга потенциальных опасностей, связанных с флюидодинамическими процессами в криосфере Западной Арктики // Современные методы обработки и интерпретации сейсмологических данных: мат-лы XI Международной сейсмологической школы (Киргизская Республика, 12-16 сентября 2016 г.) / отв. ред. А. А. Маловичко. Обнинск: ФИЦ ЕГС РАН, 2016. C. 3-9.

72. Centre for Arctic Gas Hydrate, Environment and Climate (CAGE) [Электронный ресурс] // Арктический университет Норвегии. URL: https://cage.uit.no/ (дата обращения: 28.07.2018).

73. Цукерман В. А. Проблемы и перспективы инновационнотехнологического развития экономики Севера // Экономика и управление. 2007. № 6. С. 76-78.

74. Порфирьев Б. Н., Терентьев Н. Е. Эколого-климатические риски социально-экономического развития Арктической зоны Российской Федерации // Экологический вестник России. 2016. № 1. С. 44-51.

75. Нижегородцев Р. М., Дудин М. Н., Лясников Н. В. Структурные преобразования в условиях формирования «зеленой» экономики: вызовы для бизнеса и стран БРИКС // Вестник Южно-Российского государственного технического университета (Новочеркасского политехнического института). Серия: Социально-экономические науки. 2016. № 4. C. 4-17.

76. Цукерман В. А., Горячевская Е. С. Об инновационно-промышленной политике минерально-сырьевого комплекса Арктической зоны Российской Федерации // Научное обозрение. 2015. № 10. С. 271-280.

77. Цукерман В. А. О государственном регулировании природоохранной деятельности горно-обогатительных предприятий Севера и Арктики 
России // Экологическая стратегия развития горнодобывающей отрасли формирование нового мировоззрения в освоении природных ресурсов: сб. докл. всерос. науч.-технич. конф. с участием иностранных специалистов (13-15 октября 2014 г.): в 2 т. Т. 1 / Российская академия наук; Горный ин-т Кольского научного центра РАН. Апатиты; СПб.: Реноме, 2014. С. 325-330.

78. Цукерман В. А. Состояние, проблемы и перспективы инновационного развития минерально-сырьевого комплекса Севера и Арктики России // Записки Горного института. 2011. Т. 191. С. 212-217.

79. Цукерман В. А. Ресурсосбережение и природоохранная деятельность горно-обогатительных предприятий Арктической зоны Российской Федерации // Материалы международной конференции «Ресурсосбережение и охрана окружающей среды при обогащении и переработке минерального сырья» (Плаксинские чтения - 2016) (СанктПетербург, 26-30 сентября 2016 г.) / науч. ред. акад. РАН В. А. Чантурия; сост. к. т. н., доц. Т. В. Чекушина. М.: АО «Издательский дом "Руда и металлы"», 2016. С. 373-374.

80. Ашырова М. Г. Проблемы и необходимость экологического воспитания и образования детей: цели экологического воспитания // Инновационные механизмы решения проблем научного развития: сб. ст. междунар. науч.практич. конф.: в 4 ч. (Уфа, 28 декабря 2016 г.). Уфа: ОМЕГА-САЙНС, 2016. С. 35-38 [Электронный pecypc]. URL: https://elibrary.ru/item.asp?id=27608368 (дата обращения: 18.12.2017).

81. В «Лапландии» прошел педагогический форум «От экологического образования - к экологической культуре» [Электронный ресурс]. URL: http://rsosh1.ucoz.ru/news/v_laplandii_proshel_pedagogicheskij_forum_ot_ehk ologicheskogo_obrazovanija_k_ehkologicheskoj_kulture/2017-02-28-329 (дата обращения: 04.03.2018).

82. Мельникова Р. М., Лаврушева М. В. Анализ состояния экологообразовательной среды региона (на примере Мурманской области) [Электронный ресурc]. URL: https://www.scienceforum.ru/2016/1551/16899 (дата обращения: 21.12.2017).

83. Кузнецов В. П., Чурбанова Е. С. Влияние санкций на промышленность России: оценка и последствия // Материалы III Международной научнопрактической конференции «Экономическая безопасность России: проблемы и перспективы» (Нижний Новгород, 26-28 мая 2015 г.). Нижний Новгород: изд. Нижегородского государственного технического университета им. Р. Е. Алексеева, 2015. С. 167-170.

84. Гулиев И. А., Мустафинов Р. К. Оценка влияния санкций на нефтегазовые компании России // Проблемы экономики и управления нефтегазовым комплексом. 2015. № 5. С. 41-45.

85. Цукерман В. А., Козлов А. А. О политике импортозамещения промышленного производства Севера и Арктики // Север и рынок: формирование экономического порядка. 2017. № 1. С. 113-121.

86. Новак: Снижение активности реализации арктических нефтегазовых проектов наблюдается в РФ [Электронный ресурс]. URL: http://ru.arctic.ru/resources/20170314/570588.html (дата обращения: 22.08.2017). 
87. Приразломное месторождение [Электронный ресурс]. URL: http://www.gazprom.ru/about/production/projects/deposits/pnm/ （дата обращения: 23.08.2017).

88. Штокман [Электронный ресурc]. URL: http://shtokman.ru/project/about/offshore/ (дата обращения: 23.08.2017).

89. Оценка международных стандартов для безопасной разведки, добычи и транспортировки нефти и газа в Баренцевом море (проект «Баренц-2020») [Электронный ресурс]. URL: http://textarchive.ru/c-2134313-pall.html (дата обращения: 30.12.2019).

90. Пояснительная записка к проекту национального стандарта Российской Федерации ГОСТ Р «Нефтяная и газовая промышленность. Арктические операции. Технические средства противопожарной защиты морских платформ. Общие требования» [Электронный ресурс]. URL: http://www.google.ru/url? sa $=\mathrm{t} \& \mathrm{rct}=\mathrm{j} \& \mathrm{q}=\& \mathrm{esrc}=\mathrm{s} \&$ source $=$ web $\& \mathrm{~cd}=9 \& \mathrm{ved}=0 \mathrm{a}$ hUKEwjt1OmisJ3XAhWnYpoKHdOABZcQFghCMAg\&url=http $\% 3 \mathrm{~A} \% 2 \mathrm{~F} \% 2$ Ftksneftegaz.ru\%2Fuploads\%2Fmedia\%2Fpz_gost_r_3144_11_1ya_redakciya.docx\&usg=AOvVaw0T-xmZyEeGyljhtjN36xBh （дата обращения: 01.11.2017).

91. Арктика ждет высокой цены на нефть и развития технологий [Электронный pecypc]. URL: http://tass.ru/ekonomika/4122247 (дата обращения: 23.08.2017).

92. Цукерман В. А. Инновационное промышленное развитие как основа комплексного управления экономикой Арктической зоны Российской Федерации // Север и рынок: формирование экономического порядка. 2016. № 2 (49). С. 94-105.

93. Национальный нефтегазовый форум открылся в Экспоцентре. Информация пресс-службы ЗАО «Экспоцентр» [Электронный ресурс]. URL: http://www.neftegaz-expo.ru/ru/news/index.php?id4=6992 (дата обращения: 06.11.2019).

94. «Газпром нефть» и Свердловская область будут сотрудничать в импортозамещении [Электронный pecypc]. URL: http://www.angi.ru/news/2852653--Газпром-нефть-и-Свердловская-областьбудут-сотрудничать-в-импортозамещении/ (дата обращения: 29.08.2017).

95. «Уралмаш НГО Холдинг» разработал буровую установку «Арктика» для Крайнего Севера [Электронный pecypc]. URL: http://tass.ru/ekonomika/4103989 (дата обращения: 29.08.2017).

96. Перфобур [Электронный pecypc]. URL: https://www.rvc.ru/investments/innovative_projects/81039/ (дата обращения: 29.08.2017).

97. Совместные испытания технологии с АНК «Башнефть»[Электронный pecypc]. URL: http://perfobur.com/news/sovmestnyie-ispyitaniya-texnologii-sank-bashneft.html (дата обращения: 29.08.2017).

98. ООО «Сейсмо-шельф» [Электронный pecypc]. URL: http://www.rvc.ru/investments/innovative_projects/2988/ (дата обращения: 30.08.2017).

99. Цукерман В. А., Горячевская Е. С. Добыча и переработка минеральносырьевых ресурсов Арктической зоны Российской Федерации как основа экономической безопасности страны // Россия: тенденции и перспективы 
развития. Ежегодник. Вып. 11 / РАН; ИНИОН; Отд. науч. сотрудничества; отв. ред. В. И. Герасимов. М., 2016. Ч. 3. С. 800-805.

100. Цытович Н. А., Сумгин М. И. Основания механики мерзлых грунтов. М.: AH CCCP, 1937. $432 \mathrm{c}$.

101. Ц Цытович Н. А. Механика грунтов: Полный курс. М.: Ленанд, 2014. 640 с.

102. Troll - самая высокая морская платформа в мире [Электронный ресурс]. URL: http://www.sciencedebate2008.com/highest-sea-platform/ (дата обращения: 23.09.2018).

103. Платформа «Приразломная» [Электронный pecypc]. URL: http://shelf.gazprom-neft.ru/business/mlsp_prirazlomnaya/ (дата обращения: 23.09.2018).

104. Проект «Приразломное»: основные факты [Электронный ресурс]. URL: http://shelf.gazpromneft.ru/upload/iblock/109/spravka_o_proekte_prirazlomnoe.pdf （дата обращения: 23.09.2018).

105. Далматов Б. И. Механика грунтов, основания и фундаменты (включая специальный курс инженерной геологии): учебник. СПб.: Лань, 2012. 416 с.

106. Карнаухов Н. Н., Кушнир С. Я., Горелов Ф. С., Долгих Г. М. Механика мерзлых грунтов и принципы строительства нефтегазовых объектов в условиях Севера: учебник. М.: НефтеГаз, 2008. 230 с.

107. Мангушев Р. А., Карлов В. Д., Сахаров И. И. Механика грунтов: учебник. M.: ACB, 2015. $256 \mathrm{c}$.

108. Свод правил СП 25.13330.2012. Основания и фундаменты на вечномерзлых грунтах. Актуализированная редакция СНиП 2.02.04-88. Дата введения: 01.01.2013. М.: Минрегион России, 2012 [Электронный pecypc]. URL: http://docs.cntd.ru/document/1200095519 (дата обращения: 23.09.2018).

109. Свод правил СП 21.13330.2012 «СНиП 2.01.09-91. Здания и сооружения на подрабатываемых территориях и просадочных грунтах» (утв. Приказом Министерства регионального развития РФ от 29 декабря 2011 г. № 624; дата введения: 1 января 2013 г.) [Электронный ресурс]. URL: http://hge.spbu.ru/normative/12_SP_21_13330_2012.pdf (дата обращения: 23.09.2018).

110. Богоявленский В. И. Безопасность и рациональность при добыче нефти и газа в Арктике // Экология и жизнь. Электронный журнал, выпуск от 01.04.2014 [Электронный ресурс]. www.ecolife/ru/zhurnal/articles/24671 (дата обращения: 23.09.2018).

111. Богоявленский В. И. Угроза из глубин: мерзлота ошибок не прощает // Сетевое издание «Редкие земли». 2018 [Электронный ресурс]. URL: http://rareearth.ru/ru/pub/20180123/03679.html (дата обращения: 23.09.2018).

112. Гинсбург Г. Д., Соловьев В. А. Субмаринные газовые гидраты. СПб.: ВНИИ Океангеология, 1994. 199 с.

113. Павленко В. И. Арктическая зона РФ в системе обеспечения национальных интересов страны // Арктика: экология и экономика. 2013. № 4 (12). C. 16-25.

114. Eliseev A. A., Malakhova V. V., Arzhanov M. M., Golubeva E. E., Denisov S. S., Mokhov I. I. Changes in the boundaries of the permafrost layer and the 
methane hydrate stability zone on the Eurasian Arctic shelf, 1950-2100 // Doklady Earth Sci. 2015. Vol. 465 (2). P. 1283-1288.

115. Якушев В. С. Природный газ и газовые гидраты в криолитозоне. М.: ВНИИГАЗ, 2009. $190 \mathrm{c}$.

116. Buffett B. B. Clatrate Hydrates // Annual Rev. Earth Planet Sci. 2000. Vol. 28. P. 477-507.

117. Чувилин Е. М., Буханов Б. А. Экспериментальное изучение теплопроводности мерзлых гидратосодержащих грунтов при атмосферном давлении // Криосфера Земли. 2013. Т. 17, № 1. С. 69-79.

118. Saltan N., Gaqrziglia S. Geomechanical constitutive modeling of gas-hydratebearing sediments // Proceedings of the 7th International Conference on Gas Hydrates (ICGH 2011), Edinburgh, Scotland, UK, July 17-21 2011 [Электронный pecypc]. URL: https://pdfs.semanticscholar.org/e93b/2bbb3460f8881d2da98b2f0495341afe8a0 e.pdf (дата обращения: 23.10.2018).

119. Masui A., Haneda H., Ogata Y., Aoki K. Effects of methane hydrate formation on shear strength of synthetic methane hydrate sediments // Proceeding of the 15th International Offshore and Polar Engineering Conference. Seoul, 2005. P. 364-369.

120. Sultan N, Marsset B., Ker S., Marsset T., Voisset M., Vernant A. M., Bayon G., Cauguil E., Adamy J., Colliat J. L., Drapeau D. Hydrate dissolution as a potential mechanism for pockmark formation in the Niger Data // J. Geophys. Res. 2010. Vol. 115. В 08101 [Электронный pecypc]. URL: http://adsabs.harvard.edu/abs/2010JGRB.115.8101S (дата обращения: 23.10.2018).

121. Kimoto S., Oka F., Fushita T. A chemo-thermo-mechanically coupled analysis of ground deformation induced by gas hydrate dissociation // International J. of Mechanical Sciences. 2010. Vol. 52. P. 365-376.

122. Paull C. K., Ussler W. III, Dallimore S. R., Blasco S. M., Lorenson T. D., Melling H., Medioli B. E., Nixon F. M., McLaughlin F. A. Origin of pingo-like features on the Beaufort Sea shelf and their possible relationship to decomposing methane gas hyrates // Geophys. Res. Lett. 2007. Vol. 34, No. 1. DOI: $10.1029 / 2006$ GL027977 [Электронный pecypc]. URL: https://agupubs.onlinelibrary.wiley.com/doi/abs/10.1029/2006GL027977 (дата обращения: 23.10.2018).

123. Andreassen K., Hubbard A., Winsborrow M., Patton H., Vadakkepuliyambatta S., Plaza-Faverola A., Gudlaugsson E., Serov P. Massive blow-out craters formed by hydrate-controlled methane expulsion from the Arctic Science seafloor // Science. 2017. No. 356 (6341). P. 948-953. DOI: 10.1126/science.aal4500

124. Koch S., Berndt C., Bialas J., Haeckel M., Crutchley G., Papenberg C., Kiaschen D., Greinert J. Gas-controlled seafloor doming // Geology. 2015. Vol. 43. P. 571-574.

125. Аржанов М. М., Мохов И. И. Оценки степени устойчивости континентальных реликтовых метангидратов в оптимуме голоцена и при современных климатических условиях // Доклады академии наук. 2017. Т. 476, № 4. C. 456-460. DOI: 10.7868/S0869565217280222 
126. Баренблатт Г. И., Лобковский Л. И., Нигматулин Р. И. Математическая модель истечения газа из газонасыщенного льда и газогидратов // Доклады академии наук. 2016. T. 470, № 4. C. 458-461. DOI: $10.7868 / \mathrm{S} 0869565216280148$

127. Лобковский Л. И., Рамазанов М. М. Математическая модель осесимметричного квазистационарного тепломассопереноса в газогидратном пласте // Известия РАН. Механика жидкости и газа. 2017. № 4. C. 85-96. DOI: 10.7868/S0568528117040089

128. Власов А. Н., Хименков А. Н., Волков-Богородский Д. Б., Левин Ю. К. Природные взрывные процессы в криолитозоне // Наука и технологические разработки. 2017. Т. 96, № 3. С. 41-56. DOI: $10.21455 / \mathrm{std} 2017.3-4$

129. Аржанов М. М., Мохов И. И., Денисов С. Н. Дестабилизация реликтовых метангидратов при наблюдаемых региональных изменениях климата // Арктика: экология и экономика. 2016. № 4 (24). С. 46-51.

130. Зубков П. Т., Яковенко А. В. Влияние вибрации на область с газом при адиабатических и изотермичных граничных условиях // Теплофизика и аэромеханика. 2013. Т. 20, № 1. С. 283-294.

131. Хабибуллин И. Л. Электромагнитная термомеханика поляризующих сред. Уфа: изд. Башкирского государственного университета, 2000. 246 с.

132. Макогон Ю. Ф., Саяхов Ф. Л., Хабибуллин И. Л. Способ добычи нетрадиционных видов углеводородного сырья // Доклады академии наук СССР. 1989. Т. 306, № 4. С. 941-943.

133. Авакян С. В., Воронин Н. А., Дубаренко К. А. Влияние магнитных бурь на аварийность систем электроэнергетики, автоматики и связи // Научнотехнические ведомости СПбПУ. Естественные и политехнические науки. 2012. Вып. 3, № 2. С. 253-265.

134. Беллендир Е. Н. Научное обоснование проектирования гравитационных опорных блоков морских ледостойких платформ и их сопряжения с грунтовым основанием: автореф. дис. ... д-ра тех. наук. СПб.: изд. СПбПУ, 2006. 42 с.

135. Мельников Н. Н., Калашник А. И. Шельфовые нефтегазовые разработки: геомеханические аспекты. Апатиты: КНЦ РАН, 2009. 140 с.

136. Амосов П. В., Климин С. Г., Мельников Н. Н. Результаты численного моделирования теплового состояния криолитозоны при эксплуатации многомодульной подземной атомной станции малой мощности // Арктика: экология и экономика. 2017. № 2 (26). С. 82-90. DOI: 10.25283/2223-45942017-2-82-90

137. Васильева 3. А., Якушев В. С. Влияние параметров теплоизоляции газовых скважин на интенсивность оттаивания многолетнемерзлых пород и внутримерзлотных газогидратов // Криосфера Земли. 2017. Т. 21. С. 92-98. DOI: $10.21782 / \mathrm{kz} 1560-7496-2017-5(92-98)$

138. Адзынова Ф. А., Сухоносенко А. Л. Мессояхское газогидратное месторождение // Газохимия. 2010. № 11. С. 38-40.

139. Полозков К. А., Полозков А. В, Истомин В. А., Астафьев Д. А., Гафтуняк П. И., Санников С. Г. Исследование низкотемпературных разрезов с выявлением газогидратных пластов при строительстве скважин и 
перспективы освоения газогидратных залежей // Строительство нефтяных и газовых скважин на суше и на море. 2015. № 7. С. 19-26.

140. Estimation of gas hydrate concentration from multi-component seismic data at sites on the continental margins of NW Svalbard and the Storegga region of Norway / G. K. Westbrook et al. // Marine and Petroleum Geology. 2008. Vol. 25 , No $8 . \quad$ P. 744-758 [Электронный pecypc]. URL http://dx.doi.org/10.1016/j.marpetgeo.2008.02.003 (дата обращения: 11.10.2018).

141. Detailed structure of buried glacial landforms revealed by high-resolution 3D seismic data in the SW Barents Sea / B. Bellweld et al. // 80th EAGE Conference \& Exhibition 2018 (11-14 June, 2018, Copenhagen, Denmark). Extended Abstracts. P. 1-5. DOI: 10.3997/2214-4609.201801161

142. Ампилов Ю. П., Батурин Д. Г. Новейшие технологии сейсмического мониторинга 4D при разработке морских месторождений нефти и газа // Технологии сейсморазведки. 2013. № 2. С. 31-36.

143. Boswell R., Collett T., Dallimore S., Frye M. Geohazards associated with naturally-occurring gas hydrate // Fire in the Ice (Methane Hydrate Newsletter). 2012. No. 12 (1). P. 11-16.

144. Виноградов А. Н., Виноградов Ю. А., Маловичко А. А. Применение сейсмоинфразвукового метода мониторинга природной среды для контроля геодинамического режима в зонах активного освоения недр Карского шельфа и Ямала // Вестник Кольского научного центра РАН. 2014. № 4. C. 23-32.

145. Жеребцов В. Д., Виноградов Ю. А. Перспективы применения волоконнооптической технологии для исследования нефтегазовых месторождений и мониторинга промысловых площадей на шельфе // Материалы IV Международной конференции «Шельф Арктики: стратегия будущего. Нефть и газ Арктического шельфа» (Мурманск, 12-14 ноября 2008 г.). Электронное издание. Мурманск: АрктикШельф, 2008 [Электронный pecypc]. URL: https://www.twirpx.com/file/1619349/ (дата обращения: 11.10.2018).

146. О состоянии и проблемах в законодательном обеспечении реализации Основ государственной политики Российской Федерации в Арктике на период до 2020 г. и дальнейшую перспективу: ежегодный доклад - 2010 / С. М. Миронов и др.; под общей ред. С. М. Миронова. М.: изд. Совета Федерации РФ, 2011. 85 с.

147. Favali P., Beranzoli L., De Santis A. (Eds.). Seafloor Observatories. A New Vision of the Earth from the Abyss. Chichester, UK: Springer Praxis Publishing, 2015. $672 \mathrm{p}$.

148. Левченко Д. Г., Кузин И. П., Лобковский Л. И., Рогинский К. А. Проблемы и перспективы создания глобальной сейсмологической сети суша - океан // Океанология. 2016. T. 56, № 5. С. 814-826. $10.7868 / \mathrm{S} 003015746050075$

149. Selin V. S., Larichkin F. D., Tsukerman V. A., Goryachevskaya E. S. Challenges of the national industrial development and policy of mineral mining companies in the Arctic Region of the Russian Federation // Gornyi Zhurnal. 2016. No. 10. P. 25-33. DOI: 10.17580/gzh.2016.10.04 
150. Komkov N. I., Selin V. S., Tsukerman V. A., Goryachevskaya E. S. Problems and perspectives of innovative development of the industrial system in Russian Arctic regions // Studies on Russian Economic Development. 2017. Vol. 28, No. 1. P. 31-38. DOI: 10.1134/S1075700717010051

151. Формирование основ современной стратегии природопользования в ЕвроАрктическом регионе / под ред. В. Т. Калинникова и А. Н. Виноградова. Апатиты: КНЦ РАН, 2005. $511 \mathrm{c.}$

152. Ивантер В. В., Лексин В. Н., Порфирьев Б. Н. Арктический мегапроект в системе государственных интересов и государственного управления // Проблемный анализ и государственно-управленческое проектирование. 2014. T. 7, № 6 (38). С. 6-24.

153. Виноградов А. Н. Арктика как природно-техническая мегасистема: актуальные задачи на переходе к проектному управлению развитием // Управление развитием крупномасштабных систем (MLSD' 2018): материалы 11-й междунар. конф. (Москва, 1-3 окт. 2018 г.) / под общ. ред. С. Н. Васильева, А. Д. Цвиркуна. Т. 1: Пленарные доклады, секции 1-7. М.: ИПУ РАН, 2018. С. 100-102.

154. Замятина Н. Ю., Пилясов А. Н. Новое междисциплинарное научное направление: арктическая региональная наука // Регион: экономика и социология. 2017. № 3 (95). C. 3-30. DOI: 10.15372/REG20170301

155. Виноградов А. Н., Калинников В. Т., Петров В. П. Приоритетные задачи Кольского регионального научного центра Российской академии наук по организации междисциплинарных комплексных исследований на современном этапе освоения Арктической зоны России // Вестник Кольского научного центра РАН. 2014. № 4 (19). С. 3-10.

156. Сергеев M. Импорт оборудования для шельфа заменить непросто [Электронный ресурс] // Независимая газета. URL: http://www.ng.ru/economics/2017-03-24/4_6957_import.html?print=Y (дата обращения: 06.11.2019).

157. Современные проблемы и перспективы развития арктического газопромышленного комплекса / под. науч. ред. д. э. н. С. Ю. Козьменко, д. э. н. В. С. Селина. Апатиты: КНЦ РАН, 2017. 228 с.

158. Импортное оборудование на шельфе сократят до $50 \%$ [Электронный pecypc] // Электронное издание «Вести. Экономика». URL: http://ru.arctic.ru/economics/20170323/577103.html (дата обращения: 06.11.2019).

159. Группа ЧТПЗ впервые поставила насосное оборудование для добычи нефти на Арктическом шельфе [Электронный ресурс] // Электронное периодическое издание «Нефть и Капитал». URL: https://oilcapital.ru/news/upstream/04-04-2017/gruppa-chtpz-vpervye-postavilaneftyanoe-oborudovanie-dlya-arkticheskogo-shelfa (дата обращения: 06.11.2019).

160. Сайт ПАО «Трубной металлургической компании» // Пресс-релизы. URL: https://www.tmk-group.ru/PressReleases (дата обращения: 06.11.2019).

161. Андрианов В. Импортозамещение: весь пар в гудок? // Нефтегазовая вертикаль. 2016. № 10. С. 52-57. 
162. Ампилов Ю. П. Проблемы и перспективы разведки и освоения российского шельфа в условиях санкций и падения цен на нефть // Вести газовой науки. 2015. № 2 (22). С. 5-14.

163. Чуй С. А. О ходе работ по импортозамещению технологий и оборудования для проектов, реализуемых на континентальном шельфе [Электронный pecypc] // Материалы II Всероссийской конференции «Конкурентоспособность и импортозамещение в нефтегазовом комплексе России». РГУ нефти и газа (НИУ) имени И. М. Губкина. URL: https://docplayer.ru/42057968-Programma-ii-vserossiyskoy-konferenciikonkurentosposobnost-i-importozameshchenie-v-neftegazovom-komplekse-15dekabrya-2016-goda.html (дата обращения: 30.12.2019).

164. Российская техника для Арктики. Интервью с Василием Осьмаковым // Нефтегазовая вертикаль. 2017. № 5. С. 18-19.

165. Катышева Е. Г. Экономические проблемы импортозамещения при освоении углеводородных ресурсов северных территорий России // Арктика: История и современность: тр. междунар. науч. конф. (СанктПетербург, 20-21 апреля 2016 г.) / отв. ред. д. и. н., проф. С. В. Кулик. М.: Издательский дом «Наука», 2016. 532 с.

166. Вадим Кравец RPI: Освоение российского шельфа в условиях санкций: нас бьют, а мы крепчаем? [Электронный ресурс] // ROGTEC. RUSSIAN OIL AND GAS TECHNOLOGIES. URL: https://rogtecmagazine.com/rpiосвоение-российского-шельфа-в-услов/?lang=ru (дата обращения: 07.11.2019).

167. Козлов А. А., Цукерман В. А. Развитие системы управления импортозамещающей деятельностью при добыче углеводородов на арктическом шельфе (проблемы, зарубежный опыт) // Актуальные проблемы, направления и механизмы развития производительных сил Севера - 2018: сб. ст. 6-й всерос. науч.-практич. конф. (с международным участием) (Сыктывкар, 19-21 сентября 2018 г.): в 3 ч. Сыктывкар: ООО «Коми республиканская типография», 2018. Ч. III. 341 с.

168. Банько Ю. Учиться у соседа // Нефть России. 2017. № 10. С. 18-22.

169. Сайт организации Norwegian Energy Partners. URL: https://www.norwep.com/ (дата обращения: 07.11.2019).

170. Сайт государственной программы SkatteFUNN R\&D. URL: https://www.skattefunn.no/en/soke-skattefunn/about-skattefunn/ (дата обращения: 07.11.2019).

171. Горидько Н. П., Нижегородцев Р. М., Цукерман В. А. Инновационные векторы экономического роста северных регионов: возможности, оценки, прогнозы. Апатиты: КНЦ РАН, 2013. 199 с.

172. Федеральный закон от 31 декабря 2014 г. № 488-Ф3 «О промышленной политике в Российской Федерации» // Собрание законодательства Российской Федерации от 5 января 2015 г. № 1 (часть I). Ст. 41.

173. Постановление Правительства РФ от 3 января 2014 г. № 3 «Об утверждении Правил предоставления субсидий из федерального бюджета российским организациям на компенсацию части затрат на уплату процентов по кредитам, полученным в российских кредитных организациях в 2014-2016 годах на реализацию новых комплексных инвестиционных проектов по приоритетным направлениям гражданской 
промышленности» // Собрание законодательства Российской Федерации от 20 января 2014 г. № 3. Ст. 272.

174. Постановление Правительства Российской Федерации от 30.12.2013 № 1312 «Об утверждении Правил предоставления субсидий из федерального бюджета российским организациям на компенсацию части затрат на проведение научно-исследовательских и опытно-конструкторских работ по приоритетным направлениям гражданской промышленности в рамках реализации такими организациями комплексных инвестиционных проектов в рамках подпрограммы "Обеспечение реализации государственной программы" государственной программы Российской Федерации "Развитие промышленности и повышение ее конкурентоспособности"》 // Собрание законодательства Российской Федерации. 2014. № 2. Ст. 135 (часть I).

175. Ковригина Т. А. Вопросы кадрового импортозамещения в ТЭК // Вопросы управления. 2015. № 5 (17). С. 206-211.

176. Ларичкин Ф. Д., Цукерман В. А., Козлов А. А. Кадровое обеспечение инновационного развития регионов Севера // Региональная экономика: теория и практика. 2010. № 5. С. 20-25.

177. Козлов А. А., Цукерман В. А. Об импортозамещении при добыче углеводородов на арктическом шельфе // Европейская зона российской Арктики: сценарии развития: мат-лы всерос. науч. конф. (с международным участием) (Сыктывкар, 18-19 октября 2017 г.): в 2 ч. Сыктывкар: ГОУ ВО КРАГСиУ, 2017. С. 81-85.

178. Сергеев А. Г., Терегеря В. В. Метрология, стандартизация и сертификация: учебник. М.: Юрайт, 2010. 820 с.

179. Васильева Л. В. Система классификационных признаков импортозамещения // Россия: тенденции и перспективы развития. Ежегодник. Вып. 12 / РАН; ИНИОН; Отд. науч. сотрудничества; отв. ред. В. И. Герасимов. М., 2017. Ч. 1. 984 с.

180. Козлов А. А., Цукерман В. А. Развитие импортозамещения при освоении Арктического шельфа по предложенным признакам классификации // Будущее Арктики начинается здесь: сб. мат-лов II всерос. науч.-практич. конф. с международным участием (Апатиты, 18-20 апреля 2018 г.). Апатиты: Изд-во филиала МАГУ в г. Апатиты, 2018. С. 246-252.

181. Макова Е. Арктический шельф России: степень разведанности и оценка запасов [Электронный ресурс] // Центр информационного и правового обеспечения развития Арктики. URL: http:/arcticcentre.com/ru/analitika/item/250-perspektivy-i-problemy-osvoeniya-zapasovuglevodorodov-arkticheskogo-shelfa (дата обращения: 07.11.2019).

182. В России создается отечественный комплекс нефтегазового оборудования для работы на шельфе [Электронный ресурс] // Пресс-релиз Министерства промышленности и торговли РФ. URL: http://minpromtorg.gov.ru/presscentre/news/\#!v_rossii_sozdaetsya_otechestvennyy_kompleks_neftegazovogo_ oborudovaniya_dlya_raboty_na_shelfe (дата обращения: 07.11.2019).

183. Постановление Правительства РФ от 31 марта 2017 г. № 374 «О внесении изменений в постановление Правительства Российской Федерации от 15 апреля 2014 г. № 304» // Собрание законодательства Российской Федерации от 10.04.2017. № 15 (часть III). Ст. 2209. 
184. Айсберги и ледники Баренцева моря: исследования последних лет. Ч. 1. Основные продуцирующие ледники, распространение и морфометрические особенности айсбергов / И. В. Бузин и др. // Проблемы Арктики и Антарктики. 2008. № 1 (78). С. 66-80.

185. Перечень поручений о дополнительных мерах по стимулированию экономического роста [Электронный ресурc]. URL: http://www.kremlin.ru/acts/assignments/orders/23900 (дата обращения: 07.11.2019).

186. Приказ Минпромторга России от 31.03.2015 № 645 (ред. от 07.06.2016) «Об утверждении плана мероприятий по импортозамещению в отрасли нефтегазового машиностроения Российской Федерации» [Электронный ресурс] // КонсультантПлюс: сайт. URL: http://www.consultant.ru/document/cons_doc_LAW_224887/ (дата обращения: 07.11.2019).

187. Архипов С. Импортозамещение - это развитие национальной производственной базы и системы поставщиков // Сибирская нефть. 2016. № 3 (130) C. 14-17.

188. Buyanova M., Shiro M., Kozlov A. Regional Economy Clustering as Effective Import Substitution Factor // Proceedings of the 2018 IEEE International Conference "Quality Management, Transport and Information Security, Information Technologies" (ITQM \& IS). 2018. P. 828-831.

189. Лексин В. Н., Порфирьев Б. Н. Российская Арктика сегодня: содержательные новации и правовые коллизии // Экономика региона. 2018. T. 14, № 4. C. 1117-1130.

190. Agarkov S., Kozlov A., Fedoseev S. Major trends in efficiency upgrading of the economic activity in the Arctic zone of Russian Federation // Journal of Mining Institute. 2018. No. 230. P. 209-216.

191. Kozlov A., Gutman S., Rytova E., Zaychenko I. Analysis of the Regulatory and Legal Framework of the Socio-Economic Development in the Far North Regions of Russia // Journal of Advanced Research in Law and Economics [S. 1.]. 2017. Vol. 7, No. 7. P. 1828-1836.

192. Kozlov A., Gutman S., Zaychenko I., Rytova E. The formation of regional strategy of innovation-industrial development // Advances in Intelligent Systems and Computing. 2016. No. 524. P. 115-126.

193. Комков Н. И., Селин В. С., Цукерман В. А., Горячевская Е. С. Проблемы и перспективы инновационного развития промышленного комплекса российской Арктики // Проблемы прогнозирования. 2017. № 1. С. 41-49.

194. Жаров В. С. Оценка эффективности управления инновационнотехнологическим развитием промышленных предприятий и отраслей // Север и рынок: формирование экономического порядка. 2017. № 3. С. 68-77.

195. Tsukerman V. A., Kozlov A. A. Outsourcing Noncore Activities of Industrial Enterprises in the Arctic Zone of the Russian Federation // Studies on Russian Economic Development. 2018. No. 29 (3). P. 252-256. DOI: $10.1134 / \mathrm{S} 1075700718030140$

196. Dmitrievskii A. N., Komkov N. I., Krotova M. V., Romantsov V. S. Strategic alternatives of import substitution of power equipment for the oil-and-gas sector // Studies on Russian Economic Development. 2016. Vol. 27, Issue 1. P. 21-33. 
197. Bazhanov V., Amosyonok E. Assessment of the Possibilities for the Development of Domestic Production of Oil and Gas Engineering // World of Economics and Management. 2018. Part 18, No. 1. P. 30-41. DOI: 10.25205/2542-0429-2018-18-1-30-41

198. Интервью ТАСС с губернатором Ямало-Ненецкого АО Дмитрием Кобылкиным [Электронный ресурс]. URL: https://tass.ru/interviews/2413523 (дата обращения: 25.07.2019).

199. Tsukerman V., Fadeev A., Kozlov A. Algorithm for implementing the import substitution strategy when exploiting hydrocarbons on the Arctic shelf of the Russian Federation // IOP Conference Series: Earth and Environmental Science. 2019. Vol. 302, Issue 1, 012111 (4th International Scientific Conference on Arctic: History and Modernity (Saint Petersburg, 17-18 April 2019). DOI: 10.1088/1755-1315/302/1/012111 [Электронный pecypc]. URL: https://iopscience.iop.org/article/10.1088/1755-1315/302/1/012111.

200. Цукерман В. А., Козлов А. А. Кадровое обеспечение инновационнотехнологического развития промышленного комплекса Арктической зоны Российской Федерации // Большая Евразия: Развитие, безопасность, сотрудничество. Ежегодник. Вып. 1, ч. 2 / РАН; ИНИОН; Отд. науч. сотрудничества; отв. ред. В. И. Герасимов. М., 2018. С. 500-503. 


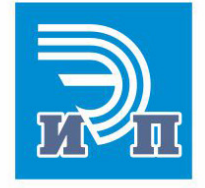

ИНСТИТУТ ЭКОНОМИЧЕСКИХ ПРОБЛЕМ ИМ. Г.П. ЛУЗИНА -

ОБОСОБЛЕННОЕ ПОДРАЗДЕЛЕНИЕ ФГБУН

ФЕДЕРАЛЬНОГО ИССЛЕДОВАТЕЛЬСКОГО ЦЕНТРА

«КОЛЬСКИЙ НАУЧНЫЙ ЦЕНТР РОССИЙСКОЙ АКАДЕМИИ НАУК»

РОССИЯ, 184209, Мурманская область, г.Апатиты, ул.Ферсмана, 24а
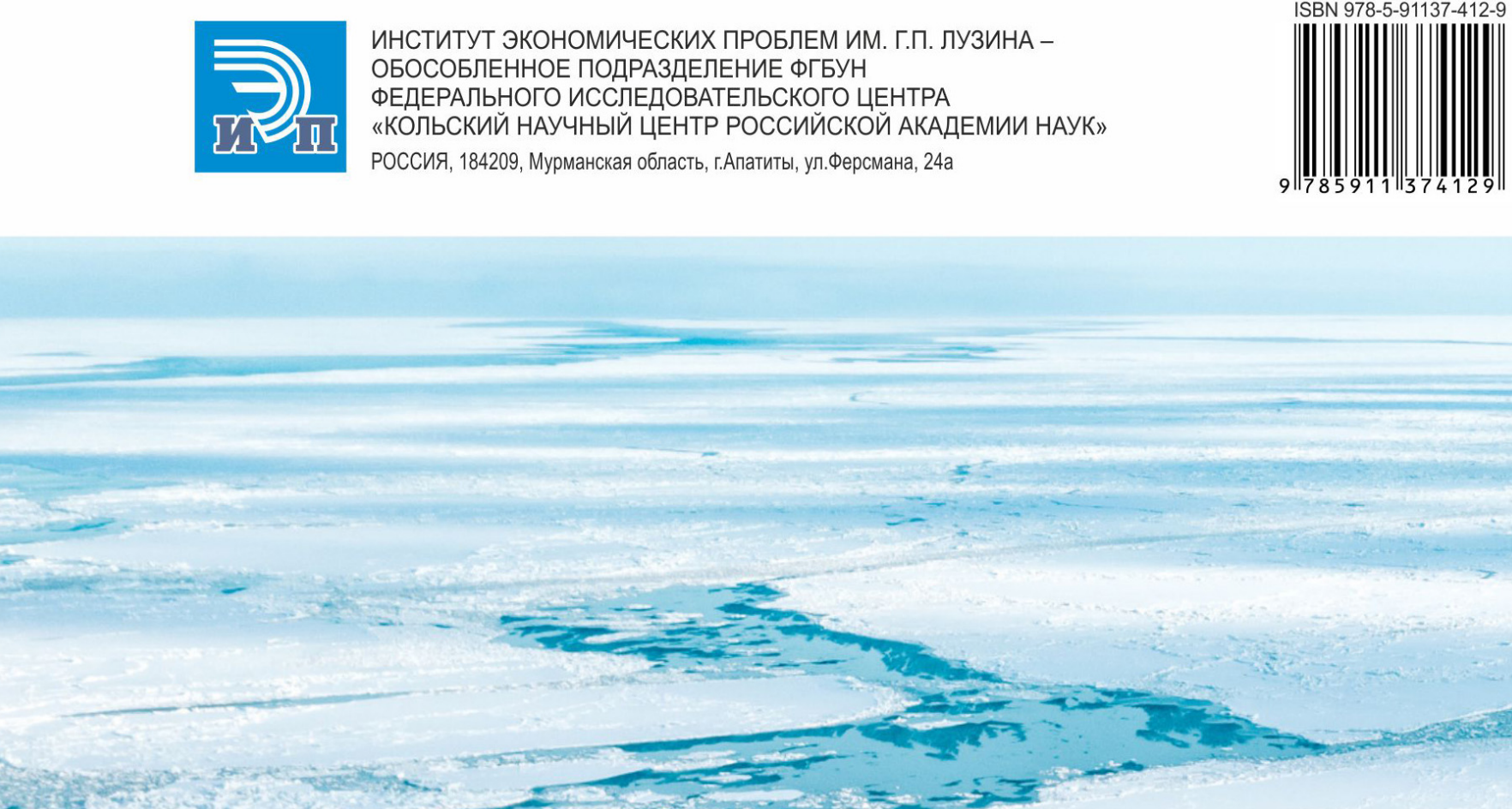

5

5

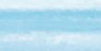

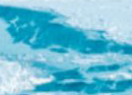

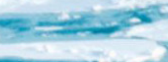
xista 25)

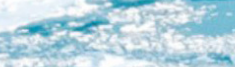

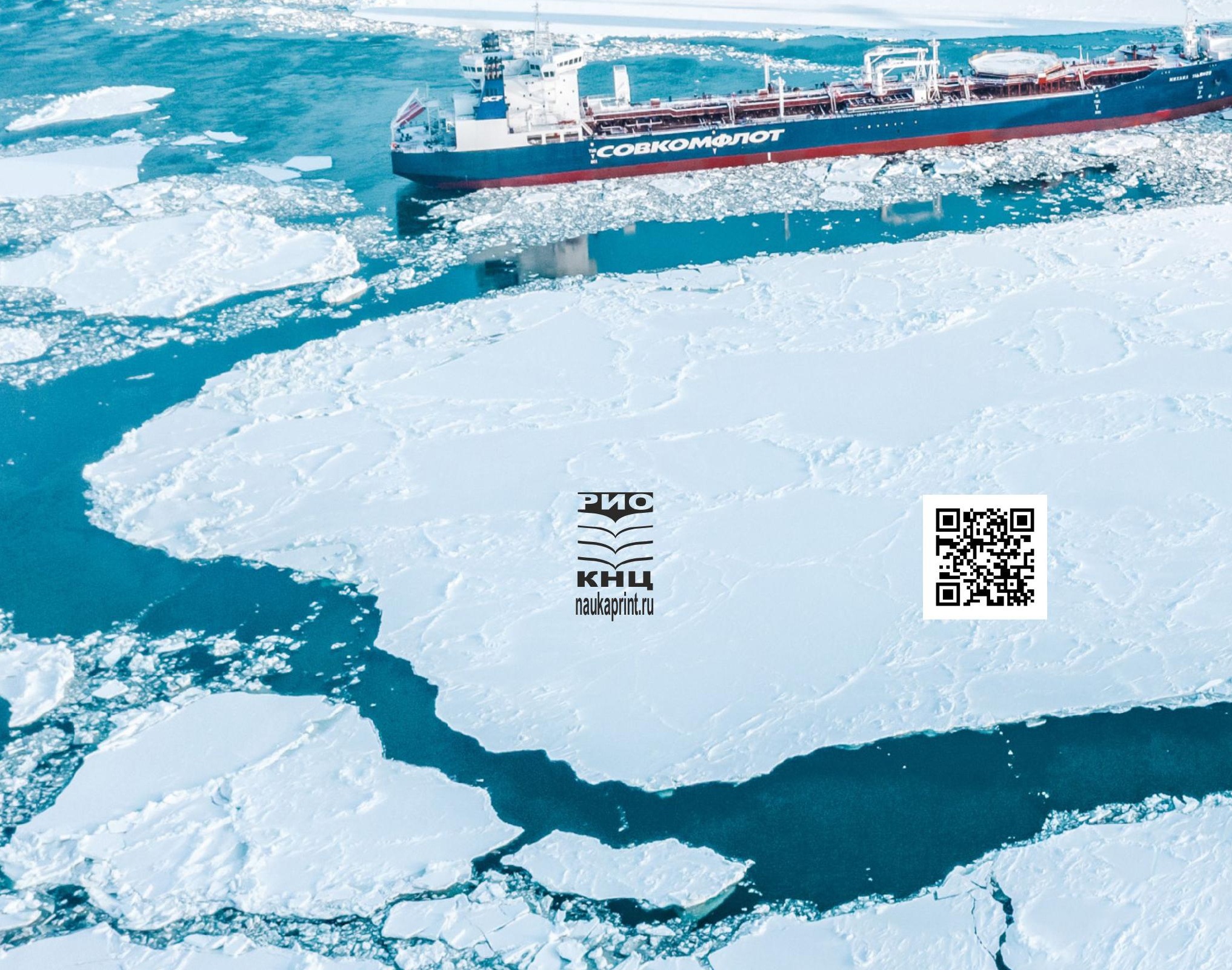

